San Jose State University

SJSU ScholarWorks

Master's Theses

Master's Theses and Graduate Research

1990

\title{
Quantification of the physical, chemical, and sensory modes of deterioration in sous-vide processed salmon
}

\author{
Beth Rachel Gittleson \\ San Jose State University
}

Follow this and additional works at: https://scholarworks.sjsu.edu/etd_theses

\section{Recommended Citation}

Gittleson, Beth Rachel, "Quantification of the physical, chemical, and sensory modes of deterioration in sous-vide processed salmon" (1990). Master's Theses. 3315.

DOI: https://doi.org/10.31979/etd.6tet-a8ay

https://scholarworks.sjsu.edu/etd_theses/3315

This Thesis is brought to you for free and open access by the Master's Theses and Graduate Research at SJSU ScholarWorks. It has been accepted for inclusion in Master's Theses by an authorized administrator of SJSU ScholarWorks. For more information, please contact scholarworks@sjsu.edu. 


\section{INFORMATION TO USERS}

The most advanced technology has been used to photograph and reproduce this manuscript from the microfilm master. UMI films the text directly from the original or copy submitted. Thus, some thesis and dissertation copies are in typewriter face, while others may be from any type of computer printer.

The quality of this reproduction is dependent upon the quality of the copy submitted. Broken or indistinct print, colored or poor quality illustrations and photographs, print bleedthrough, substandard margins, and improper alignment can adversely affect reproduction.

In the unlikely event that the author did not send UMI a complete manuscript and there are missing pages, these will be noted. Also, if unauthorized copyright material had to be removed, a note will indicate the deletion.

Oversize materials (e.g., maps, drawings, charts) are reproduced by sectioning the original, beginning at the upper left-hand corner and continuing from left to right in equal sections with small overlaps. Each original is also photographed in one exposure and is included in reduced form at the back of the book.

Photographs included in the original manuscript have been reproduced xerographically in this copy. Higher quality $6 " \times 9$ " black and white photographic prints are available for any photographs or illustrations appearing in this copy for an additional charge. Contact UMI directly to order.

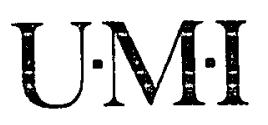

University Microfilms Internatıonal

A Bell \& Howell Information Company 

Quantification of the physial, chemical, and sensory modes of deterioration in sous-vide processed salmon

Gittleson, Beth Rachel, M.S.

San Jose State University, 1990

Copyright $(\mathcal{C} 1990$ by Gittleson, Beth Rachel. All rights reserved.

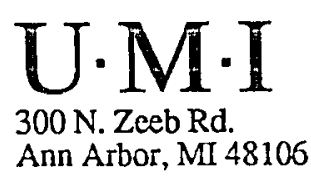



NOTE TO USERS

THE ORIGINAL DOCUMENT RECEIVED BY U.M.I. CONTAINED PAGES WITH SLANTED PRINT. PAGES WERE FILMED AS RECEIVED.

THIS REPRODUCTION IS THE BEST AVAILABLE COPY. 

QUANTIFICATION OF THE PHYSICAL, CHEMICAL, AND SENSORY MODES OF DETERIORATION IN SOUS-VIDE PROCESSED SALMON

\author{
A Thesis \\ presented to \\ The Faculty of the Department of \\ Nutrition and Food Science \\ San Jose state University
}

In Partial Fulfillment

of the Requirements for the Degree

Master of Science

in Nutritional science

By

Beth Rachel Gittleson

August 1990 
APPROVED FOR THE DEPARTMENT OF

NUTRITION AND FOOD SCIENCE

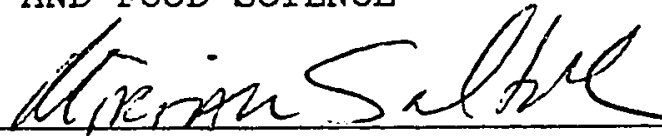

Dr. Miriam Saltmarch, Ph.D., Graduate Advisor

Department of Nutrition and Food Science

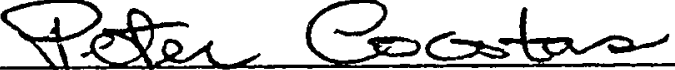

Peter Cocotas, M.S., Pharmeceutical and Food

Specialists,

lum Me poud

Dr. Luty McProud, Ph.D., R.D., Department

Chairperson, Department of Nutrition and Food

Scienge

Sot Koffinas

Rob Robbins, Director of Quality Systems

Culinary Brands, Inc.

APPROVED FOR THE UNIVERSITY

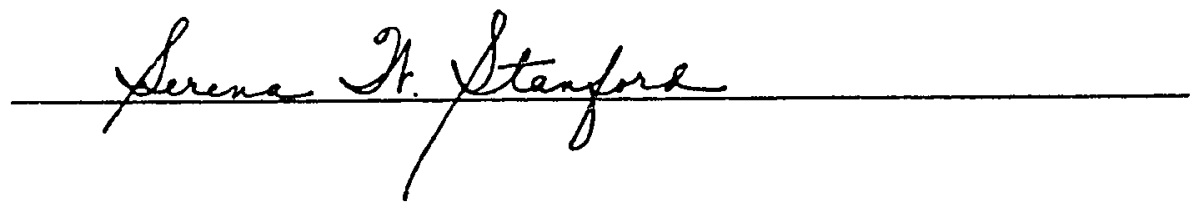




\begin{abstract}
QUANTIFICATION OF THE PHYSICO-CHEMICAL MODES
\end{abstract} OF DETERIORATION IN SOUS-VIDE PROCESSED SALMON

by Beth R. Gittleson

The purpose of this thesis was to quantify various physical, chemical, and sensory modes of deterioration in sous-vide salmon. In addition, two types of packaging materials were studied: 1) a two-web coextrusion using nylon/ethyl vinyl alcohol (EVOH)/linear low density polyethylene (LLDPE) as the forming web and nylon/ polyvinylidene chloride (PVDC)/LLDPE as the non-forming web and 2) a nylon/LLDPE pre-formed pouch.

Commercially processed sous-vide salmon fillets were stored under refrigerated conditions $\left(0-4^{\circ} \mathrm{C}\right)$ for twelve weeks. Results indicated that drip volume increased substantially during storage, regardless of package type. Total nitrogen concentration in the total dxip volume per fillet also increased in all samples. Thiobarbituric Âcid values showed increases; however, levels did not indicate rancidity. Sensory evaluation data showed that the saimon fillets were acceptable through the duration of the study. 


\section{ACKNOWLEDGEMENTS}

I especially acknowledge my advisor, Dr. Miriam Saltmarch, because this accomplishment would not have been possible without her constant patience, guidance, and support.

Culinary Brands, Inc. deserves acknowledgement for providing all the sous-vide salmon required to complete the study. A special note of appreciation goes to Rob Robbins and Miles Bennett for their cooperation and support.

I gratefully acknowledge my sensory panel for their time, patience, and diligence required to participate in this study.

Peter cocotas is acknowledged for conducting the permeability tests on the packaging films and for his technical input regarding the packaging aspects.

I acknowledge Ben Weitzel for his advice and assistance in conducting the statistical analyses of the sensory data.

paul Thibault is acknowledged for his assistance in running the Universal Testing Machine.

Melissa Lewis is acknowledged for her advice and assistance in conducting the microbiological assays.

Dr. Panfilo Belo is acknowledged for his technical advice regaraing laboratory procedures prior to and throughout the study. 


\section{DEDICATION}

My Thesis is dedicated to my husband, Paul Lewis Thibault. Because of his love, emotional support, and unselfish devotion I was able to complete this research and achieve my goal without compromising our relationship. 
PREFACE

This thesis is written in publication style. The second chapter is written in the journal format according to the 1990 style guide for research papers and will be submitted to the Journal of Food science. The first and third chapters are written according to the guidelines outlined in the publication Manual of the American Psychological Association, third edition, 1983. 
Table of contents

PAGE

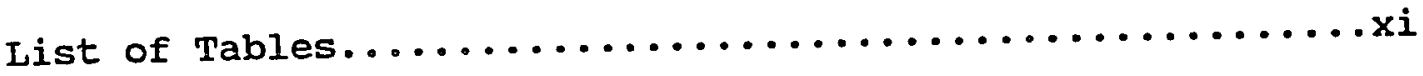

List of Figures.............................

CHAPTER

1 INTRODUCTION AND REVIEW OF THE LITERATURE............

Introduction. ..........................

objectives.........................4

significance of the study $\ldots \ldots \ldots \ldots \ldots \ldots \ldots \ldots \ldots$

Review of the Literature...................

The Sous-vide Process for Salmon.............

Preparation.......................

Packaging.........................

Heat Processing $\ldots \ldots \ldots \ldots \ldots \ldots \ldots \ldots \ldots \ldots$

Cooling.........................

Microbiological Parameters..............6

Fish spoilage.......................

Microbiological Decay.................

Microrganisms associated with fish

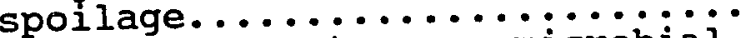

Effect of temperature on microbial growth in fish.................

Effect of atmosphere on microbial

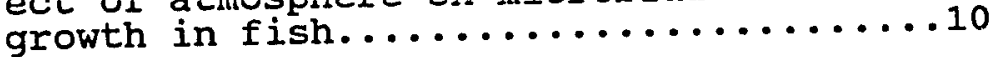

Effect of microorganisms on fish quality $\ldots 12$

Chemical Changes and Their Relationship

to Fish Quality...................14

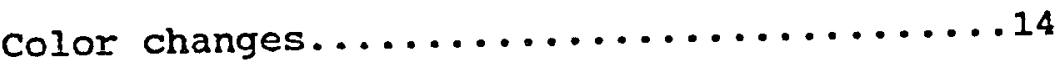

Lipid oxidation..................16 
Production of trimethylamine and related compounds................21

Textural Changes and Their Relationship

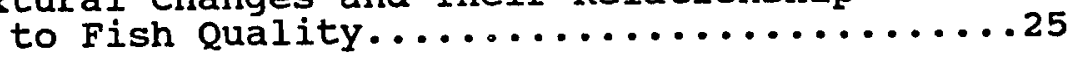

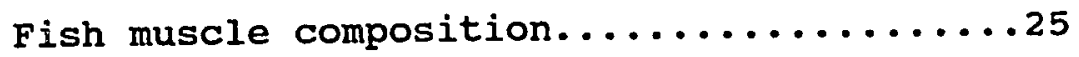

Extractable protein nitrogen..........26 Water-holding capacity..............28

Packaging Systems and the Preservation

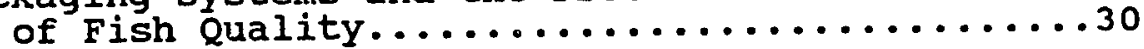

Principal packaging systems used for

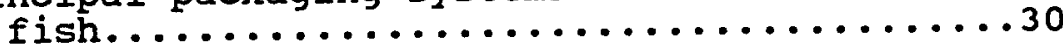

Safety of vacuum and modified atmosphere

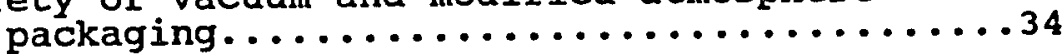

Summary of Literature Review.............40

2 JOURNAL ARTICLE......................... 46

Author's Title Page.....................47

Abstract............................... 48

Introduction...........................

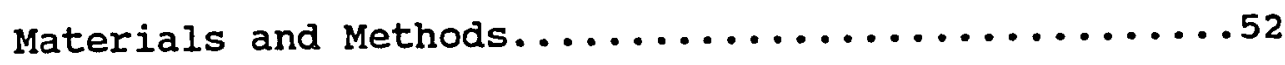

Results and Discussion.................... 61

Summary and Conclusions...................... 74

References Cited........................ 75

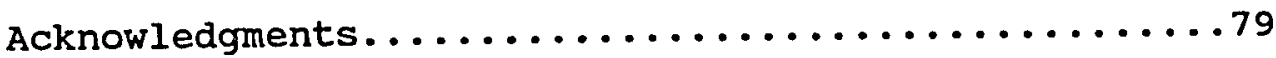

3 SUMMARY AND RECOMMENDATIONS.....................

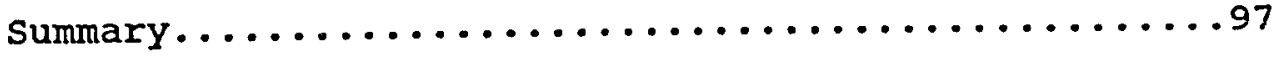

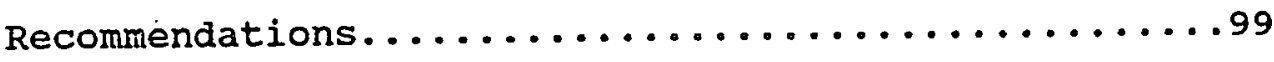

4 REFERENCES.................................... 101

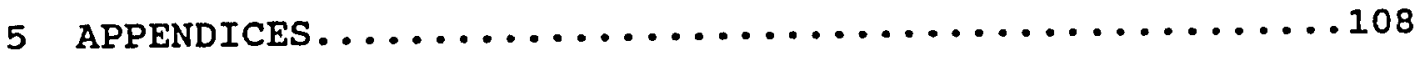

Appendix A: Sensory Evaluation Scoresheet........109

Appendix B: Human Consent Form.................. viii 
Appendix c: Instron Measurements for Salmon in the PVDC/EVOH Package.........113

Appendix D: Instron Measurements for Salmon in the Nylon/LLDPE Package........115

Appendix E: Malonaldehyde Concentration of Salmon in the PVDC/EVOH Package....117

Appendix F: Malonaldehyde Concentration of Salmon in the nylon/LLDPE Package..118

Appendix G: Non-Protein Nitrogen Content in the Drip for the PVDC/EVOH Package.....119

Appendix H: Non-Protein Nitrogen Content in the Drip for the nylon/LLDPE Package...121

Appendix I: Total Nitrogen Content in the Drip for the PVDC/EVOH Package.....123

Appendix J: Total Nitrogen Content in the Drip for the nylon/LLDPE Package.......125

Appendix K: Protein Nitrogen Content in the Drip for the PVDC/EVOH Package....127

Appendix L: Protein Nitrogen Content in the Drip for the nylon/ILDPE Package...129

Appendix M: Drip Volume in the PVDC/EVOH Package...........................

Appendix N: Drip Volume in the nylon/LLDPE Package...................133

Appendix 0: Vacuum Retention in the PVDC/EVOH package.....................135

Appendix P: Vacuum Retention in the nylon/LLDPE

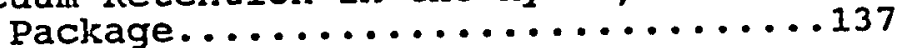

Appendix Q: Total Psychrophilic Count of the Salmon in the PVDC/EVOH Package....139

Appendix R: Total Psychrophilic Count of the Salmon salmon in the nylon/LIDPE Package..141

Appendix s: Lactobacilli Counts of the Salmon in the PVDC/EVOH Package.........143

Appendix T: Lactobacilli Counts of the Salmon 145 
Appendix U: Total Anaerobe/Facultative Counts of the Salmon in the PVDC/EVOH $\ldots . .147$

Appendix V: Total Anaerobe/Facultative Counts of the salmon in the nylon/LLDPE

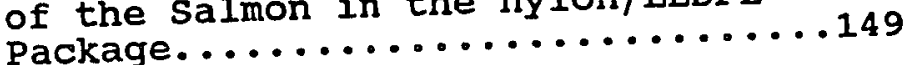

Appendix $w:$ Yeast counts of the salmon in the PVDC/EVOH Package............151

Appendix $X:$ Yeast Counts of the salmon in the nylon/LLDPE Package.........153

Appendix $\mathrm{Y}$ : Hunter Color Data....................... 


\section{List of Tables}

TABLE

PAGE

1 Rate Constants for Physical and Chemical Data.......80

2 Shelf-Life Endpoints for Physical and Chemical Data...81

3 Slopes of Change with Time for sensory Attributes....82

$x i$ 
List of Figures

FIGURE

PAGE

1 Changes in drip volume during storage............83

2 Changes in total nitrogen concentration per $m l$ drip during storage.......................... 84

3 Changes in total nitrogen concentration in the total drip volume per fillet during storage............85

4 Changes in protein nitrogen concentration per $m \mathrm{~d} d r i p$

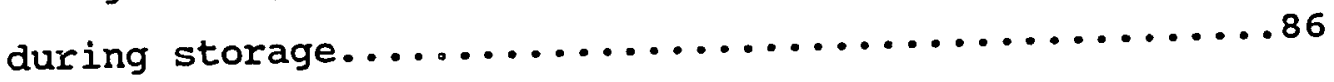

5 Changes in protein nitrogen concentration in the total drip volume per fillet during storage........87

6 Changes in non-protein nitrogen concentration per $\mathrm{ml}$

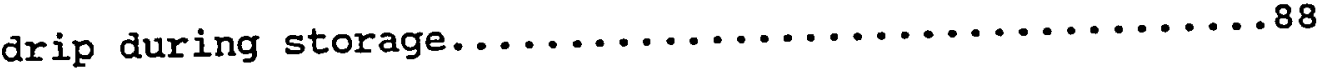

7 Changes in non-protein nitrogen concentration in the total drip volume per fillet during storage........89

8 Thiobarbituric acid values during storage...........90

9 Growth of pshycrophiles during storage... ........91

10 Growth of Lactobacillus during siorage.............92

11 Growth of anaerobes/facultatives during storage......93

12 Sensory evaluation color scores over time..........94

13 Sensory evaluation scores for fishy aroma over time...95

14 Sensory evaluation scores for overall acceptability

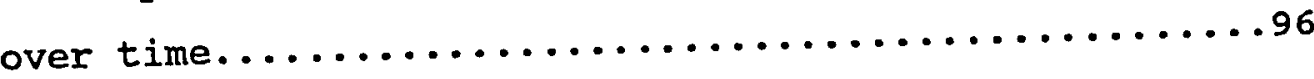


CHAPTER 1

INTRODUCTION AND REVIEW OF THE IITERATURE

Introduction

Sous-vide, a French word for "under vacuum,"

was first developed by chef George Pralus in France in the mid 1970s (Swientek, 1989). Sous-vide describes a sophisticated technique whereby freshly prepared foods are vacuum sealed into individual packages and subsequently pasteurized to destroy all vegetative pathogens (Kramer, 1988). Current refrigerated shelf-life ranges from two to three weeks, depending on the product (Swientek, 1989). The shelf-life for sous-vide salmon is currently set at 21 days when stored at $32^{\circ} \mathrm{F}$; however, the actual safe shelf-life is thought to be longer based upon microbiological challenge studies. The shelf-life of fresh fish is only a few days at refrigerated storage temperatures.

since the food is cooked in the package, all natural juices, product weight, and portion size are preserved (Anonymous ${ }^{2}, 1988$ ). In addition, flavor, freshness, color, and nutritive value are maintained (Kramer, 1988). For the foodservice operator, sous-vide offers increased haute cuisine menu selection and skilled labor reduction because preparation is simplified. The two to three week shelf-life minimizes loss and waste. In addition, capital investment in food preparation and storage equipment is reduced (Swientek, 1989). The potential is there for safe high quality meals, presentation, and improved service while 
eating out (Smith, 1988). For the supermarket and retailer, sous-vide offers convenient meal selections with a fresh, upscale, and high-quality image (Swientek, 1989).

There is a small group of manufacturers that produce sous-vide products, but the number is expected grow rapidly over the next few years (Anonymous ${ }^{b}, 1989$ ). According to Culinary Brands, Inc. president, Carl Randall, "we're talking about fine-chef capability in a pouch." This concept may revolutionize the foodservice industry in the United states, and is already doing so in Europe. Dieter Hannig, director of food research for Hilton International co., says that sous-vide "is going to be the way of the future" (Levine \& Rossant, 1987).

However, the safety of foods packaged via vacuum and/or modified atmosphere which have not received sufficient heat treatment to yield a shelf-stable product is of great concern (Baker \& Genigeorgis, 1989). These conditions may create favorable environments for growth of surviving pathogenic bacteria during prolonged product storage at low temperatures. There is great concern with respect to types $B, E$, and $F$ of clostridium botulinum because of its ability to produce neurotoxin without signs of organoleptic spoilage (Baker \& Genigeorgis, 1989). Other organisms have also been shown to grow at refrigerated temperatures, including Listeria monocytogenes, Yersinia enterolytica (Densford, 1988), Aeromonas hydrophilia, and Vibrio parahemolyticus (Genigeorgis, 1988). In addition to concerns regarding 
potentially hazardous conditions within the package, the Food and Drug Administration fears that proper procedures may not be followed during processing or that foods could be temperature-abused during transport and/or storage (Densford, 1988). Numerous investigators (Abrahamsson, Gullmar, \& Molin, 1966; Barnett, Conrad, \& Nelson, 1987; Garcia, Genigeorgis, \& Lindroth, 1987; Post et al., 1985; stier et al., 1981) have studied vacuum and modified atmosphere packaged raw fish. While these studies provide valuable information regarding the stability of non-heattreated $f i s h$, the shelf-life of heat-pasteurized vacuum packaged fish still remains to be evaluated. At this point in time, only one study has been conducted on sous-vide products. Baker and Genigeorgis (1989) conducted microbial challenge tests on 51 sous-vide products using Listeria, clostridium, and salmonella cultures.

In addition to evaluating the microbiological safety of sous-vide products, other modes of degradation should be addressed. Since a food can deteriorate via physical and/or chemical modes in addition to microbiological decay, it is important to also study these mechanisms in order to accurately predict shelf-life. Establishing these parameters will facilitate market expansion for the "state of the art" sous-vide process and concurrently provide for a safe food of optimum quality. 


\section{objectives}

The objectives of this study were: 1) to quantify various physical, chemical, and sensory modes of deterioration in sous-vide processed salmon; 2) to determine shelf-life endpoints based upon each mode of deterioration evaluated; and 3 ) to evaluate the relative influence of two types of packaging materials on the rate of deterioration.

\section{significance of the study}

The results of this study will be used in conjunction with available microbiological data to accurately predict the safe shelf-life of sous-vide salmon. According to Genigeorgis (1988), every product must be independently evaluated for modes of deterioration and the determination of which mode will occur first. Data reported by other investigators on deteriorative mechanisms in a particular food are not applicable to other food products because every food product is unique with regard to its chemical and physical composition.

Due to the newness and uniqueness of the sous-vide method, studies evaluating microbiological, chemical, and physical modes of deterioration are necessary in order to expedite the use of this method in the food industry. Not until all of the deteriorative parameters have been quantified and shelf-life endpoints determined, can the process of sous-vide be utilized by the foodservice industry with confidence. 


\section{Review of the Literature \\ The Sous-vide Process for Salmon.}

\section{Preparation}

Fresh Norwegian salmon (Salmo salar) fillets arrive at the Culinary Brands, Inc. facility skinless and boneless, stored at $36^{\circ} \mathrm{F}$. Each fillet is carefully hand trimmed into a 6-ounce portion (actual weights range from 5.8 to 6.2 ounces) by an employee wearing whites and gloves. The batch of fillet portions is then weighed and tumbled in a $1.48 \%$ sodium tripolyphosphate (TPP) solution with ice and salt at 5 psi for approximately 20 minutes. TPP is used in order to improve moisture retention within the muscle tissue.

When the TPP treatment is completed, the fish is removed and re-weighed. The percent of pickup by the salmon portions of the TPP solution is legally defined so careful monitoring of this procedure is necessary. The salmon fillets are stored in tubs at $36^{\circ} \mathrm{F}$ overnight.

\section{packaging}

The following day the salmon fillets are vacuum packaged and heat pasteurized. The cryovac $640 \mathrm{film}$ is used to package the salmon. A conveyor type of vacuum-packaging equpiment is utilized to simultaneously pull a 27 " vacuum (range 26" to 28") and seal the fillet within the package material. The package is subsequently inspected to insure that it is free from air bubbles, the seal is adequate, and the date is correct. Once packaged, the salmon fillets are heat processed within one hour to prevent bonding between 
the salmon and the package material.

\section{Heat Processing}

Salmon fillets are placed in a single layer upon stainless steel racks and heat pasteurized in a convection oven using moisture-saturated air. Thermocouples are inserted into two salmon fillets, one each on the top and bottom racks. Thermocouples are hooked up to a temperaturemonitoring device which gives a digital readout and graphs the temperature curve. The salmon fillets are heated to a legal pasteurization temperature, held for a certain period of time, and then removed.

\section{Cooling}

After heat processing, samples are immediately placed into a $40^{\circ} \mathrm{F}$ ice water bath until internal temperature reaches $40^{\circ} \mathrm{F}$. The salmon packages are transferred to a refrigerator and stored at $36^{\circ} \mathrm{F}$ until the following day. The packages are labeled with time/temperature dot indicators which change color when temperature abuse has occurred. The dot indicator automatically changes color after the "use by" date, indicating the product should not be used. The salmon packages are then boxed and are ready for shipping.

\section{Microbiological Parameters}

When the salmon arrives at the facility, it is evaluated microbiologically for total plate count and coliforms. Total plate count must be less than one million per gram, and coliform count must be less than ten per gram. 
After processing is complete, the packaged salmon is again evaluated. Total plate count must be less than 1,000 per gram, and coliform count must be less than one per gram.

\section{Fish Spoilage}

As soon as the fish dies, spoilage begins. spoilage is a complex process caused by a number of inter-related systems. The development of oxidative rancidity and the action of microorganisms are significant causes of degredation in iced fresh fish after death (Londahl, 1981). Microbiological Decay

Microorganisms associated with fish spoilage. Microorganisms normally are present in fish in the surface slime on the gills and in the intestines; the muscle is sterile. Shewan (1977) reported that these bacteria appeared to remain dominantly on the surface of the fish, but secreted enzymes into the tissues (Liston, 1982). The spoilage pattern depends somewhat on the species and type of fish, the initial microbial flora, the area of catch, the method of catch, processing method, and method of storage (Banwart, 1981). Recent investigations have shown that in most cases the bacterial population shifts toward a spoilage population of Pseudomonas and Pseudomonas-like bacteria (Liston, 1982): Alur et al. (1971) isolated Pseudomonas, proteus, Aeromonas, and Achromobacter from spoiled $f i s h$. In addition, cytophaga, coryneforms, Micrococcus, Bacillus, Vibrio, Flavobacterium, and 
clostridium have been encountered in fresh and spoiling fish (Banwart, 1981). Vacuum packaging of fish changes the spoilage flora in a manner similar to fresh meat.

Lactobacillus and Microbacterium grow and cause souring, and the aerobic Pseudomonads are inhibited (Banwart, 1981).

A worldwide surge of interest in clostridium botulinum type $E$ occurred after a series of outbreaks of type $E$ botulism during the 1960 s in the scandinavian countries, the United States, Canada, and Japan (Abrahamsson et al., 1966). Bott et al. (1966), Craig et al. (1968), Eklund and Poysky (1967), Fantasia and Duran (1969), Foster et al. (1965), and Insalta et al. (1967) reported that these outbreaks were caused predominantly by the nonproteolytic type E strains of clostridium botulinum in fish products which were consumed without further heat processing (Post et al., 1985) - Today, there is a large body of evidence that indicates that fresh fish may be contaminated with clostridium botulinum organisms either as a result of the organisms being present in the microbiota of the fish ecosystem or as a result of post-catching contamination during processing (Post et al., 1985).

Effect of temperature on microbial growth in fish. One of the most important environmental factors that regulates the growth of microorganisms is temperature. Temperature not only affects the organism's ability to grow, but also to survive. In addition, cell size, metabolic products, nutritional requirements, enzymatic reactions, and the 
chemical composition of cells are all affected by temperature (Banwart, 1981).

Every organism has a minimum, optimum, and maximum growth temperature. Usually the optimum temperature is based upon the rate of growth. Minimum and maximum temperatures are those beyond which the organisms cease to grow. In general, organisms can show some growth at temperatures considerably lower than the optimum; however, when the temperature is increased above the optimum, there is a very rapid decline in growth rate. Above the maximum temperature, growth ceases and the life of the cell is in jeopardy (Banwart, 1981).

Psychrophiles grow at low temperatures. Morita (1975) suggested that psychrophiles had an optimum temperature of $15^{\circ} \mathrm{C}$ or lower, a maximum of about $20^{\circ} \mathrm{C}$, and a minimum of around $0^{\circ} \mathrm{C}$ or lower. Psychrotrophs also grow at low temperatures, but do not necessarily meet this definition. Psychrotrophs can grow up to $40^{\circ} \mathrm{C}$, whereas psychrophiles do not. In addition, psychrophiles can grow as low as $-15^{\circ} \mathrm{C}$ while psychrotrophs only grow as low as $-5^{\circ} \mathrm{C}$. Mesophiles grow well at temperatures between $25^{\circ} \mathrm{C}$ and $50^{\circ} \mathrm{C}$ and thermophiles between $35^{\circ} \mathrm{C}$ and $90^{\circ} \mathrm{C}$ (Banwart, 1981).

Clostridium botulinum type $E$, non-proteolytic type $B$, and type $F$ are found in fish and have been show to grow as low as $3.3^{\circ} \mathrm{C}$. However, the spores produced by these organisms are heat labile (Hackney \& Dicharry, 1988). In addition the combination of $\mathrm{pH}$ and temperature can affect 
organism growth. For instance, spores of clostridium botulinum type $\mathrm{E}$ were shown to grow at $15.6^{\circ} \mathrm{C}$ and $\mathrm{a} \mathrm{pH}$ of 5.4 to 5.6 , but at $5^{\circ} \mathrm{C}$, a pH of 6.2 to 6.4 was needed for the spores to germinate (Banwart, 1981).

A further discussion of the temperature requirements of microorganisms associated with fish spoilage can be found in the section on safety of vacuum and modified packaging. Effect of atmosphere on microbial growth in fish. The gaseous atmosphere surrounding a food may determine the types of organisms that become dominant. Aerobic organisms will grow in the presence of oxygen, while facultative anaerobes will grow without oxygen, such as in a vacuum (Banwart, 1981). Modified atmosphere (MA) describes an environment, such as within a package, whereby the composition of the atmosphere is different than that of air (Hintlian \& Hotchkiss, 1986). Vacuum packaging is actually a form of MA. Modified atmosphere packaging (MAP) extends the shelf-life of refrigerated fresh foods by reducing the surface redox potential and changing the atmosphere within the package (Baker \& Genigeorgis, 1989).

The oxidation-reduction potential (Eh) is a measure of the tendency of a reversible system to give or receive electrons. When a substance becomes oxidized, it loses electrons. These electrons must be accepted by another substance, which then becomes reduced.

Simultaneous oxidations and reductions are the sources of energy for microbial cell processes. It has been well 
established that the Eh drops in the substrate or medium as organisms metabolize. The lowering of the Eh has been ascribed to the consumption of oxygen or the production of reducing substances (Banwart, 1981).

With aerobic bacteria, there is a slight lowering of the Eh during the lag phase of growth. During the log phase of growth, the oxygen usage increases, causing a subsequent decrease in the Eh. As the Eh becomes negative, growth decreases (Banwart, 1981).

Facultative anaerobes lower the Eh similar to aerobes, but at a much slower rate. However, as the organisms reach the stationary phase, the Eh shifts to a more positive value. Clostridium botulinum will grow at Eh levels from +85 to $+160 \mathrm{mv}$ (Banwart, 1981).

The redox potential of a food depends upon the natural redox potential, the oxygen tension in the atmosphere, and the access the food has to the atmosphere. Due to the complications of determining the Eh of foods and the variations due to atmospheric influences, the redox potentials of only a few foods are available (Banwart, 1981).

The normal spoilage pattern due to spoilage microorganisms in a MA shifts from one dominated by psychrotrophic aerobic bacteria responsible for slime, rancidity, and discolorations to one dominated by the slower growth of facultative anaerobes (Baker \& Genigeorgis, 1989). The safety of MAP will be reviewed in the packaging section 
of this chapter.

Effects of microorganisms on fish quality. Modern analytical procedures have revealed a wide range of odorous compounds present in spoiling fish, incluaing ethyl mercaptan, methyl mercaptan, dimethyl sulfide, dimethyl disulfide, hydrogen sulfide, diacetyl, acetaldehyde, propionaldehyde and many others. The sulfur-containing compounds are capable of producing the objectionable odors of spoilage, for example, rotten egg odor, a cabbage-like odor, and a musty sourness. When the number of bacteria that produce these odors exceeds 1,000,000/gram, significant amounts of sulfur-containing compounds are produced and spoilage becomes organoleptically evident (Liston, 1982). Acetic, butyric, propionic, and hexanoic acid esters are breakdown products of glycine, serine, and leucine and produce fruity odors. Basic compounds derived from amino acids and urea produce ammoniacal and fishy odors (Liston, 1982).

The primary substrate for bacterial growth and the main source of spoilage products is the dissolved material in the muscle. Meat studies have indicated that Pseudomonas preferentially utilize carbohydrate, then lactic acid, and finally selected amino acids for growth. It is hypothesized that the same occurs in fish; however, since carbohydrate content is low in $\mathrm{fish}$, amino acids would be the primary substrate (Liston, 1982).

Pseudomonas rapidly utilize most amino acids and 
peptides found in the non-protein nitrogen (NPN) fraction of muscle (Liston, 1982). The primary mode of utilization appears to be oxidative deamination, which could result in the production of ammonia and volatile fatty acids. studies conducted during the 1960 s showed that not all bacteria occurring in spoiling fish were capable of producing typical objectionable spoilage odors when grown in pure culture on sterile fish muscle or muscle press juice at low temperatures $\left(0^{\circ}-10^{\circ} \mathrm{C}\right.$ ) (Liston, 1982). In many cases microorganisms produced trimethylamine and other volatile bases, causing a fishy odor.

The breakdown of trimethylamine oxide (TMAO) has been implicated in the spoilage of both fresh and frozen fish. It is found in most species of marine fish and is particularly high in the gadoid (cod, haddock, pollock) and the elasmobranch families (sharks, etc.). It appears that TMAO participates in the osmoregulation and in the buffering system of these fish. It is a water-soluble compound and a part of the non-protein nitrogen fraction of total nitrogen (Regenstein, Schlosser, Samson, \& Fey, 1982).

Many gram-negative psychrotrophic bacteria have the capability of using TMAO. Whether these organisms are only able to use TMAO under anaerobic conditions has not yet been proven (Regenstein et al., 1982). Achromobacter is thought to be capable of reducing TMAO to trimethylamine (TMA), however, TMA production is preceded by a lag period of three to four days. By this time, Pseudomonas putrefaciens 
becomes the dominant organism and may be responsible for up to 808 of TMA production (Regenstein et al., 1982).

Trimethylamine is a volatile compound which has a very low odor threshold. Ikeda (1979) reported that TMA has an odor threshold of 600 parts per billion (ppb). TMA is associated with the fishy odor of spoilage and is clearly a part of the spoilage pattern in many fish species (Regenstein et al., 1982). It is important to note that TMA is mostly associated with marine species of $\mathrm{fish}$ and is generally not applicable to fresh water species (Connell, 1975) .

During the process of $f$ ish spoilage the pseudomonads decrease in numbers, and the Achromobacter species return to be the dominant organisms. The rise in $\mathrm{pH}$ and the possible inhibitory effect of high levels of TMA may be responsible for a decrease in the pseudomonads (Regenstein et al., 1982).

Chemical Changes and Their Relationship to Fish Quality

color changes. The overall quality of marine food products is related to a number of factors, including flavor, color, and texture. The color of a fish or seafood product is the first characteristic noted by a consumer and is directly related to the acceptance or rejection of the product (Simpson, 1982).

The carotenoids are a group of pigments responsible for yellow, orange, and red colors that occur in various types of seafood and fish, such as salmon, trout, red snapper, 
clams, oysters, etc. Astaxanthin is perhaps the major pigment in seafood and is responsible for the color of salmon (Simpson, 1982). The compound has been shown to be present in the mono- or diester form in the skin and in the free form in the flesh. It is interesting to note that it tends to be one of the most unstable of the carotenoids. The degradation of carotenoids is of extreme importance in fish and seafood. Exposure of carotenoids to strong light can cause cis/trans isomerization which produces a slight shift in color. Exposure to light and hydrogen ions can cause the formation of carbonyl products and epoxides, which result in a loss of color. Drying processes also result in a loss of color. The drying of fish and fish meals and subsequent storage are responsible for the most detrimental changes in color. Vacuum and tray drying have both been shown to dramatically reduce the level of carotenoids (Simpson, 1982).

The carotenoids are also known to act as substrates for lypoxygenase, although natural antioxidants occur in fish and seafood. A lipoxygenase-like enzyme was isolated and partially purified from the skin of red $f i s h$, including Sebastes thompsoni and chelidonichthys kumu by Tsukuda and Amano in 1967 (Simpson, 1982). This enzyme was noted to be heat-labile. The investigators observed that discoloration of red fish occurred at refrigeration temperatures in the dark, and that homogenates from the skin, muscle, and liver were able to cause degradation of astaxanthin, tunaxanthin, 
and beta-carotene to colorless compounds (Simpson, 1982).

Lipid oxidation. Fish oils contain a greater variety of fatty acids than other oils or fats and have a considerably greater amount of fatty acids with chain lengths containing 20 to 22 carbons. These long chain fatty acids generally make up one-fourth to one-third of all the fatty acids in fish oils, and even approach one-half in certain species. In addition, there are substantial levels of highly polyunsaturated fatty acids, commonly five and six double bonds per fatty acid chain, and long chain omegathree fatty acids (Stansby, 1982).

In most cases, fish oils occur as triglycerides. However, all fish have a small amount of their lipid occurring at the cellular level in the form of phospholipids. Most of these phospholipids in marine fish occur either as phosphatidyl cholines or as phosphatidyl ethanolamines. To a lesser extent, fish phospholipids occur in other forms, including inositol phosphatides, cerbrosides, and sphingomyelins (stansby, 1982). Species of fish that often contain $10 \%$ or more oil, such as herring and salmon, have a large proportion of their lipids occuring as triglycerides (Stansby, 1982).

Iipid oxidation is a major cause of spoilage in fish muscle due to the highly unsaturated nature of the fatty acids (Hutlin, McDonald, \& Kelleher, 1982). Moerck and Ball (1974) showed that fatty acids that had three or more double bonds were very susceptible to oxidation during refrigerated 
storage of muscle foods, and that the suceptibility

increased with the number of double bonds in the fatty acid (Melton, 1983).

Although the importance of lipid oxidation in fish tissue has been recognized, the mechanisms of the oxidative process are not well understood. It is known, however, that certain metals, such as iron, catalyze lipid oxidation in fish (Hutlin et al., 1982). other catalysts include high temperatures, peroxides, enzymes, level of oxygen pressure, and light (ultraviolet and blue). Catalysts are necessary in the process, otherwise the reaction occurs too slowly to be significant (Aurand, Woods, \& Wells, 1987).

Factors which inhibit lipid oxidation include freezing and refrigeration, metal sequesterants, antioxidants, blanching, inert gas and vacuum packaging, and hydrogenation of unsaturated fatty acids (Erickson \& Bowers, 1976). Labuza (1971) has stated that lipid oxidation proceeds rapidly at temperatures within the range of $0^{\circ}$ to $-18^{\circ} \mathrm{C}$ with a maximum oxidation rate at about $-4^{\circ} \mathrm{C}$. Below $-18^{\circ} \mathrm{C}$, the rate of Iipid oxidation decreases (Licciardello, Ravesi, \& Allsup, (1982).

A mechanism for the autoxidation of a methyleneinterrupted unsaturated system was proposed by Holman in 1954 (Aurand et al., 1987). In the initiation step, a hydrogen atom was abstracted from the methylene carbon atom adjacent to a double bond. This reaction resulted in the formation of a free radical. The free radical was a 
resonance hybrid. Molecular oxygen added to the ends of the resonating compound. The free radicals could further accept hydrogen atoms and became hydroperoxides, therefore propagating the reaction. These hydroperoxides were unstable and decomposed to form short-chain acids, alcohols, ketones, and aldehydes. These end products were responsible for the development of the odor and flavor of oxidized fats (Aurand et al., 1987).

The most common objective test used to follow lipid oxidation in foods is the Thiobarbituric Acid (TBA) Test (Melton, 1983). This method involves the spectrophotometric determination of a red pigment formed between 2-thiobarbituric acid and the oxidation products of unsaturated fatty acids. In 1958, Sinnhuber, Yu, and Yu had shown that the compound malonaldehyde was produced during lipid oxidation and was probably involved in the reaction with 2-Thiobarbituric acid to form the red pigment (Pearson, 1977). Various procedures have been employed for performing the TBA test on food products. The distillation procedure developed by Tarladgis, Watts, Younathan, and Dugan (1960) is the most common method used for TBA analysis (Melton, 1983). The test is performed on the whole food rather than on extracted fat. The method would therefore measure oxidation products of protein-bound lipids and phospholipids which would not have been extracted by ordinary fat solvents (Tarladgis et al., 1960). Aurand et al. (1987) reported that the TBA method gave a more accurate picture of fat 
oxidation than the older color tests, the Kreis Test and Peroxide Value technique. Melton (1983), however, commented that the distillation procedure gave consistently higher values than those determined by the method of analyzing food fat extracts.

TBA values of four or greater were regarded by Sinnhuber and $\mathrm{Yu}(1958)$ to be indicative of an unacceptably rancid product (Licciardello et al., 1980). According to Ellinger (1972), TBA values were excellent guides to rancidity development and that the detectable limit of rancid odors for cooked fish, beef, pork, veal, lamb, and chicken was a TBA value of one-half to one. Licciardello et al. (1982) reported that flavor scores were correlated with TBA numbers in hake species. The TBA number corresponding to borderline acceptability was determined from the regression line between flavor score and $T B A$ value to be five. Ke et al. (1975) reported a TBA value of six for mackerel which had deteriorated.

Unda, Molins, and walker (1990) reported a rapid decline in TBA values in meat as bacterial spoilage increased during storage at $2^{\circ}$ to $4^{\circ} \mathrm{C}$. Moerck and Ball (1974) also reported decreases in TBA reactive substances in meat undergoing bacterial spoilage (Unda et al., 1990). Polyphosphates have been reported to be effective antioxidants in foods containing fats in an aqueous environment (Ellinger, 1972). Zipser and Watts (1961) studied the combined effect of sodium tripolyphosphate and 
sodium ascorbate on the rate of lipid oxidation in cooked ground mullet fillets. After two and five days of storage at $5^{\circ}$ to $7^{\circ} \mathrm{C}$, the samples were evaluated by the TBA method and a sensory panel. Results indicated there were antioxidant effects which protected against the detection of off-odors by the sensory panel. TBA numbers were lower in the samples treated with sodium tripolyphosphate/sodium ascorbate than untreated control samples, regardless of the storage period. In addition, sensory scores remained high for these samples, whereas in the untreated control samples, sensory scores decreased as TBA numbers increased.

other investigators reported that the treatment of fish with a combination of $12 \%$ sodium tripolyphosphate and $4 \%$ salt effectively inhibited development of rancidity. Results from this same study also indicated that TBA values remained significantly lower in the fish treated with sodium tripolyphosphate than untreated control samples (EIIinger, 1972) .

Another study showed no effect on lipid hydrolysis due to dipping fish fillets in a sodium tripolyphosphate solution prior to freezing with subsequent thawing. Yet another study demonstrated that treatment of fish fillets prior to freezing with a $12.5 \%$ sodium tripolyphosphate and salt solution had no effect on preventing the development of rancidity. It was thought, however, that the sodium tripolyphosphate dip could have been masking the manifestations of deterioration rather than offering 
protection from deteriorative factors (Ellinger, 1972).

In addition to investigation of the protective effects of sodium tripolyphosphate and other salts in meat and fish, packaging alternatives have been examined. Barnett et al. (1987) studied the boned trout, treated or not treated with a $2.3 \%$ potassium sorbate dip and packaged in laminated high/low density semi-permeable polyethylene bags with a carbon dioxide-enriched atmosphere. Results revealed that storing the trout in the carbon dioxide environment did not suppress development of oxidative rancidity as measured by the TBA test, regardless of the potassium sorbate dip. There was a gradual increase in oxygen in the headspace gas that apparently contributed to oxidative effects as manifested by increased TBA values.

significant increases in TBA values occurred in the trout between the tenth and eighteenth day of storage; however, a sensory panel could not detect rancidity in cooked samples. The investigators attributed this to the fact that when the fish was cooked, unpleasant odors were volatilized and therefore, not detected by the sensory panel. Other investigators (Bilinski et al., 1979; Hansen, 1972; Liljemark, 1964; Tarr, 1948) have shown that packaging under vacuum or inert gas environments were effective in suppressing devlopment of rancidity in frozen fish (Licciardello et al., 1982).

- Production of trimethylamine and related compounds. A number of different tests are used for estimating the degree 
of spoilage in fish, including total bacterial numbers, total volatile bases, trimethylamine (TMA), total volatile reducing substances indol sensory analyses, refractive index of the eye fluid. electrical resistance of the fish flesh, volatile acids, volatile ammonia, and total volatile nitrogen (Londahl, 1981). Bacteria growing on the surface of the fish tissue produce volatile amines. One such volatile base is TMA, a reduction product of the component trimethylamine oxide (TMAO). TMAO is reduced to trimethylamine after death and is thought to be part of the main metabolic pathway for nitrogen elimination in elasmobranchs. TMAO levels have been reported to be $40 \mathrm{mg}$ to $120 \mathrm{mg} / \mathrm{kg}$ fish (Belitz \& Grosch, 1987), but vary considerably between different species of $f i s h$ and between fish of the same species (Hebard, Flick, \& Martin, 1982). Two types of enzymes are considered to be responsible for the reduction of TMAO to TMA, dimethylamine (DMA), and formaldehyde. These are endogenous enzymes in $f i s h$ and exogenous enzymes produced by certain bacteria during spoilage (Hebard et al., 1982). Kawabata (1953) reported that TMA increased markedly in the dark muscle of freshly caught albacore and frigate mackerel stored under aseptic conditions. No such increase was observed in the white muscle of the same fish (Hebard et al., 1982). TMAOreducing ability was strongly diminished or inhibited when muscle preparations were treated with heat or with dipyridyl or potassium cyanide, substances known to have an inhibitory 
influence on enzymes with heavy metal cofactor, especially iron. From this data, Kawabata concluded that the dark muscle of pelagic fish contained an enzyme capable of reducing TMAO. Suyama (1960) also reported TMA formation under aseptic conditions in the dark muscle of Mustelus manazo and Dasyatis akajei (Hebard et al., 1982). Tokunaga (1970) further substantiated that an endogenous enzyme existed in the dark muscle. He noted that the TMA and DMA began to form soon after the death of the fish, and that only negligible amounts were formed in white muscle (Hebard et al. 1982).

Tomizawa (1951) was the first person to extract TMAO reductase from Escherichia coli. This enzyme was shown to be membrane-bound in E. coli and in Vibrio parahemolyticus. Yamamoto and Ishimoto (1977) and Ishimoto and Shimkawa (1978) found that E. Coli reduced TMAO in anaerobic respiration. Cytochrome $c$ acted as an electron carrier linked to TMAO reductase (Hebard et al., 1982).

The strains of bacteria capable of reducing TMAO to TMA have been found in most species of the Enterobacteriaceae, including E. coli, Achromobacter, Micrococcus, Flavobacterium, nonflourescent pseudomonas, clostridium, Alcaligenes, and Bacillus species. In some cases, no correlation was observed between bacterial growth and TMA production because the number of TMA-producing bacteria was small compared to the number of spoilage bacteria. In other cases, however, the two correlated very well (Hebard et al., 
1982) .

Nevertheless, TMA level has been used as an indicator of general fish spoilage and is currently one of the established procedures for determining fish quality (Londahl, 1981). Although TMA is associated with fish odor, it does not produce the odor by itself. The fishy odor is produced when TMA reacts with fat in the muscle of fish. Beatty and Gibbons (1937) found that the TMA level in cod muscle press juice rose rapidly from the almost negligible level in fresh fish at the onset of spoilage and correlated with odor production. odors always appeared at a TMA level of 4-6 mg $\mathrm{N} / 100 \mathrm{ml}$ press juice. At a level of $10 \mathrm{mg} / 100$ ml, there were definite off-odors (Hebard et al., 1982). It has been proposed that TMA levels between $5 \mathrm{mg}$ and $10 \mathrm{mg} / 100$ gram fish tissue be considered as the maximum allowable levels in international trading (Londahl, 1981).

In addition to TMA, the amine fraction of the nonprotein content in fish contains dimethylamine (DMA), monomethylamine, ammonia, and other amines derived from amino acid decarboxylation (Belitz \& Grosch, 1987). DMA was first found by Beatty (1938) in cod muscle press juice. Reay (1938) and Shewan (1939) also found small amounts of DMA in cod and haddock, respectively. DMA and formaldehyde (FA) were isolated from Atlantic cod (Dyer \& Mounsey, 1945), haddock (Dyer \& Mounsey, 1945; Shewan, 1939), Alaska pollock (Amano et al., 1963; Tokunaga, 1964), and Pacific cod (Amano et al., 1963). Shewan noted that DMA began to form 
immediately after the death of fish preceding the production of TMA (Hebard et al., 1982).

The presence of $F A$ in $f i s h$ was not suspected until Amano et al. (1963) extracted formyl dimedone from cod. He noted that the quantities of DMA and FA were highest in the viscera of fish, intermediate in the skin, and lowest in the muscle. In 1965, Yamada and Amano found relatively high concentrations of FA in fresh crab, particularly in the hepatopancreas (Hebard et al., 1982).

There are two proposed pathways to explain the production of DMA and FA. One pathway involves the enzymatic reduction of TMAO to TMA by trimethylamine monoxygenase, and the second pathway involves a nonenzymatic oxidative $\mathrm{N}$-demethylation yielding DMA and FA directly from TMA (Hebard et al., 1982).

In 1958, ota found DMA in canned mackerel, salmon, and squid after pressure-heating at $115^{\circ} \mathrm{C}$. The amount of DMA produced was almost proportional to the TMAO content of each species, being high in squid and low in salmon. Amano et al. (1968) detected DMA in canned mackerel, squid, king crab, smoked herring, fermented squid, and skipjack, but not in canned shrimp and pink salmon, while TMA was present in all samples (Hebard et al., 1982).

Textural Changes and Their Relationship to Fish ouality Fish muscle composition. Fish contains approximately 17-20\% crude protein. Protein nitrogen content of the fish muscle is about 2-3\% (Belitz \& Grosch, 1987). The protein 
nitrogen fraction includes 20-30\% sarcoplasmic proteins that are soluble in water and dilute buffer solutions (Spinelli \& Dassow, 1982). Sarcoplasma proteins consist mainly of enzymes (Belitz \& Grosch, 1987). The remaining 70-80\% are structural proteins which are soluble in cold neutral salt solutions of fairly high ionic strength. In addition, 2-3\% is connective tissue, also referred to as collagen (Spinelli \& Dassow, 1982).

Non-protein nitrogen constituents comprise between $0.5-$ 1\% of total weight of fish muscle. The major components include trimethylamine oxide, urea, taurine, peptides, amino acids, nucleotides, and related purine-based compounds (Spinelli \& Dassow, 1982).

Extractable protein nitrogen. Aside from deterioration by microorganisms and oxidative rancidity, the most conspicuous physical change that affects fish quality is an alteration in textural integrity (Spinelli \& Dassow, 1982). Alterations in texture have mostly been studied using frozen fish muscle since a steady toughening occurs during frozen storage and is readily noticed upon eating the thawed product. Toughening is presumed to reflect a change in the structural proteins actin and myosin (Love, 1983). According to Love (1983), a decrease in the amount of soluble, heat-coagulable protein in fish cold-stored for extended periods of time was first reported by clark and Almy - (1920). Reay (1933) reported that the proteins most affected were soluble only in dilute salt solutions, and not 
in water (Love, 1983). Dyer (1951) stated that extraction of soluble protein, followed by an estimation of the actomyosin content in the solution, gave an indication of the degree of protein denaturation. In addition, he reported that the soluble actomyosin decreased faster than the taste panel scores. In 1976, sikorski et al. (Godber, Wang, Cole, \& Marshall, 1989) further supported the relationship that reduced protein extractability was due to the denaturation and aggregation of proteins. Belitz and Grosch (1987) also concluded that any change in muscle texture was primarily due to a change in protein solubility. Many investigators have correlated extractable protein nitrogen (EPN) or salt-soluble protein with changes in organoleptic properties of muscle. In 1979, Gil et al. reported that cooking decreased EPN bY $95 \%$, whereas poor frozen storage caused a higher degree of toughening with only a small change in EPN. Generally, EPN has correlated very well with organoleptic properties when fish was held under poor frozen storage conditions $\left(-10^{\circ} \mathrm{C}\right)$, but not under colder storage conditions $\left(-26^{\circ} \mathrm{C}\right.$ ) (Spinelli and Dassow, 1982) .

Another theory proposed by Godber et al. (1989) for the textural deterioration of proteinaceous foods was that products of lipid oxidation interacted with proteins to form insoluble aggregates. These investigators reported that Castell (1971) suggested that low levels of Thiobarbituric Acid (TBA)-reactive compounds were interacting with 
proteins.

In 1965, Amano and Yamada (Spinelli \& Dassow, 1982)

suggested that trimethylamine oxide was degraded to

dimethylamine and formaldehyde by an enzyme. They

postulated that the liberated formaldehyde reacted with

structural proteins to produce textural changes.

Investigations by Tokunaga in 1964 and by Castell et al. in

1973 (Spinelli \& Dassow, 1982) also revealed that

formaldehyde, a possibie breakdown product of trimethylamine oxide, reacted with structural proteins and reduced protein extractability and caused related textural changes.

Marsh and Leet (Hutlin, 1976) have shown that meat toughness increased as muscle fibers shortened, up to a point where the muscle was approximately $60 \%$ of its rest length. However, with greater shortening, the muscle lost toughness rapidly. Drip losses did not become excessive until shortening exceeded about $60 \%$ of the original length (Hutlin, 1976).

Water-holding capacity. Textural changes also include a significant decrease in water-holding capacity (Spinelli \& Dassow, 1982). Water-holding capacity is a term that has been used to describe the water retention of muscle foods (Regenstein, 1984). A number of methods are employed to measure this functional property. The two major techniques are water binding potential (WBP) and expressible moisture (EM) (Regenstein, 1984). Regenstein and Laird (1985) reported that expressible moisture may be a better monitor 
of textural changes in gadoid minces than the more traditional method of measuring dimethylamine.

Regenstein (1984) reported that WBP tends to be pH dependent, whereas EM is not. In trout muscle, WPB increased dramatically above $\mathrm{pH} 7.0$, but showed relatively no change between pH 5.0 to 7.0. Below pH 5.0, WBP increased again. Percent EM, however, decreased steadily as pH increased. Results from trout muscle studies indicated that entire changes in WBP could be predicted solely from changes in $\mathrm{pH}$. Studies with various salts conducted by Regenstein (1984) also indicated that WBP was more sensitive to changes in anionic strength than cationic strength, whereas EM was cation-dependent. Salts, especially the polyphosphates, and alkaline $\mathrm{pH}$ 's, increase the water retention of muscle foods (Regenstein, 1984). Several hypotheses exist to explain this occurrence: 1) condensed polyphosphates cause an increase in the $\mathrm{pH}$ of the food system, resulting in increased electrorepulsion and hydration; 2) the relatively large charge on dissociated polyphosphate ions could increase hydration by a large, nonspecific increase in ionic strength; 3) a sequestration of divalent cations, especially calcium and magnesium, might increase hydration by decreasing the number of salt bridges between individual protein molecules, myofibrils, and muscle fibers; and 4) a specific polyphosphate-protein interaction, such as the dissociation of actomyosin by pyrophosphate (Goldsmith, 1980). 
In 1977, Aitken and Connell (Spinelli \& Dassow, 1982) investigated water-holding capacity and concomitant textural changes with respect to changes in the interfilament distance of muscle fibers. They reported that a loss of water-holding capacity and toughening occurred with no significant alterations in interfilament distances. The authors concluded that the protein change was due to an increase in hydrophobic properties.

The measurement of texture in fish has been and still is a very difficult problem (Samson, Regenstein, \& Laird, 1985). Assessment of texture by a trained sensory panel is less reliable than assessment of flavors and is expensive. In addition, results from one laboratory tend to be inconsistent with those of another laboratory. Continuing research is needed in this area in order to obtain a satisfactory objective measurement of texture quality in fish (Love, 1983).

\section{Packaging systems and the Preservation of Fish Quality}

\section{Principle Packaging Systems for Fish}

There are three basic types of flexible packaging materials used for foods: films, laminates, and bags or pouches. There are several packaging systems available to produce prepacked fresh and frozen fish and seafood for the retail market (Anderson, 1983). There is the familiar overwrapped package which utilizes a clear or printed 
stretch film around a styrofoam tray. The film is tightly stretched while being drawn around the product, then lightly heat sealed under the tray bottom. Another common package is the thermoformed laminate package that is used to wrap retail sandwich meats and cheese. A bottom film web is heated and formed into a rigid or flexible bottom container. The product is then placed into this molded shape and a nonforming web is pulled over the top of the product and sealed on all four sides. This package can be made with little air removal, a high vacuum, or can be gas fiushed to yield a modified atmosphere package (Anderson, 1983).

Vacuum skin packaging is another type of thermoforming technique being used on a limited basis. Generally, a layer of film is heated, then subjected to a vacuum which pulls the material down around the product. The product itself acts as the forming mechanism. This type of packaging is applicable to irregularly shaped products (Anderson, 1983).

The shrinkable bag is a system whereby a trayed product is inserted into a bag that is air-evacuated, heat sealed, and shrunk in a hot water tank. This package appears to be quite similar to the conventional tray over-wrapped product (Anderson, 1983).

In addition, other packaging systems are being developed in order to satisfy specific needs of the chilled and frozen product market. For instance, Printpac-UEB, located in New Zealand, has developed a system called CAPTECH. It is a high-carbon dioxide, low-oxygen packaging 
system capable of extending shelf-life of lamb from eight weeks to more than sixteen weeks, pork and poultry to ten weeks, and beef and venison to twenty weeks (Anonymous ${ }^{c}$, 1989).

Gideco Pierre Carre developed a system whereby fish is coated with a protein film. The codimer system packages fish in thermoformed plastic packs with an exudate absorption layer and maintains a high carbon dioxide atmosphere in the pack (Anonymous d, 1985). Pinneys Smokehouses of Brydekirk, Annan specialize in producing high-quality Scottish and Norwegian salmon. Their new packaging system utilizes a machine to pre-shape trays from web fed heavy guage, transparent $250 \mathrm{U}$-polyvinyl chloride/100 micron polyethylene laminate. After manual filling of the trays, the internal atmosphere within the pack is automatically adjusted to ensure a shelf-life from eight to ten days in a chill cabinet, then heat-sealed with a laminate of 15 micron polyester/60 micron polyethylene (Anonymous ${ }^{e}, 1983$ ).

Culinary Brands, Inc. produce a variety of sous-vide products using cryovac's low density polyethylene non-oxygen barrier vacuum pouch and a two-webbed vacuum low density polyethylene film with an ethyl vinyl alcohol barrier. Holden du cros also utilizes packaging films manufactured by Cryovac to market smoked salmon (Bradfield, 1984).

- Vacuum packaging in gas impermeable, airtight packages can be used for extending the shelf-life of fresh muscle 
foods (meat, poultry, fish) and perishable foods packaged before and after processing. The extension of shelf-life in a vacuum packaged fresh muscle food is dependent upon initial microbial load, the types of organisms, storage temperature, and integrity of the package (Genigeorgis, 1988).

An alternative to vacuum packaging is the use of artificial atmospheres--modified atmospheres. Various gases, including carbon dioxide, oxygen, and nitrogen, may be used to create a modified atmosphere within a package. Each gas has a specific function in the extension of refrigerated storage. Carbon dioxide $\left(\mathrm{CO}_{2}\right)$ selectively inhibits certain microorganisms, however, this process is not well-understood. Molds, yeasts, and aerobic bacteria are highly succeptible to $\mathrm{CO}_{2}$. Facultative bacteria may or may not be inhibited by $\mathrm{CO}_{2}$, while the lactic acid bacteria and anaerobes are very resistent (Genigeorgis, 1988). According to Eklund (1982), in a $\mathrm{CO}_{2}$ environment, growth of Gram-negative pseudomonads and other Gram-negative psychrophiles is selectively suppressed. These organisms normally contribute to the development of off-flavors and odors. The Gram-positive streptococci and lactobacilli are more tolerant to high concentrations of $\mathrm{CO}_{2}$ and often become the dominant flora. Growth of the Gram-positive organisms is relatively slower and is usually accompanied by only mild organoleptic changes.

The bacteriostatic effect of $\mathrm{CO}_{2}$ is affected by its 
concentration, age and load of initial bacterial population, storage temperature, type of food, and pH. Increasing $\mathrm{CO}_{2}$ concentration extends the lag phase of microorganism growth and reduces the growth rate. Lower storage temperatures and lower initial microbial loads increase the effectiveness of $\mathrm{CO}_{2}$. At lower temperatures, greater dissolution of the gas into the food occurs (Genigeorgis, 1988).

The major functions of oxygen in a modified atmosphere environment are to enhance color and odor, to maintain the oxygenated form of myoglobin, and to prevent the irreversible conversion of myoglobin to metmyoglobin. These factors are most important with regard to packaged red meats.

Nitrogen has been used to overcome extreme exudation and meat distortion caused by some vacuum packaging techniques. Nitrogen has been shown to increase the incidence of off-odor and not to inhibit aerobic bacterial flora on pork meat when present as $100 \%$ of the atmosphere. Nitrogen is also used with other processed foods to decrease distortion (Genigeorgis, 1988).

Safety of Modified Atmosphere and Vacuum Packaging

Since extending the shelf-life of refrigerated foods is currently a major concern of the food industry, many alternatives are being investigated, including product formulation, irradiation, and packaging. Because of recent safety concerns and consumer demands, the more favorable approach may be packaging (Hintlian \& Hotchkiss, 1986). The 
use of modified atmosphere packaging has proven to be successful in extending the shelf-life of many fresh and processed perishable foods. However, the application of modified atmosphere conditions cannot be used to eliminate the risk from microbial hazards (Genigeorgis, 1988).

Hanna et al. (1976) isolated Yersinia enterolitica from vacuum-packaged beef and lamb (Hintlian \& Hotchkiss, 1986). This finding has raised questions regarding the presence of this organism in other foods. According to Gill and Tan (1980), the respiration rate of Yersinia decreased and the generation time increased in carbon dioxide (Hintlian \& Hotchkiss, 1986). In addition, Eklund and Jarmund (1983) reported inhibition of Yersinia in a carbon dioxide environment (Hintlian \& Hotchkiss, 1986).

clostridium prefringens growth has been observed in fresh ground beef packaged aerobically or under vacuum and at temperatures as low as $6.5^{\circ} \mathrm{C}$. Numbers of Aeromonas hydrophila increased 10-1000 fold during storage of meat, poultry, seafood, and raw milk at $5^{\circ} \mathrm{C}$, and vacuum packaging did not delay growth (Baker \& Genigeorgis, 1989).

post et al. (1985) inoculated cod, whiting, and flounder with 50 spores per gram of clostridium botulinum type $\mathrm{E}$ and stored samples in carbon dioxide, nitrogen, a modified atmosphere containing 65-90\% co /2-4\% oxygen, or vacuum at temperatures ranging from $4^{\circ} \mathrm{C}$ to $26^{\circ} \mathrm{C}$. Toxin was detected in all fish species after one to three days storage at $26^{\circ} \mathrm{C}$. Normal rejection by a sensory panel occurred prior 
to toxin production in the vacuum packaged fish; however, in the carbon dioxide-flushed packages, normal rejection occurred after toxin detection in the samples. Absolute rejection (sample was putrid) always occurred simultaneously with or after toxin detection for both packaging techniques. The authors concluded that vacuum and modified atmosphere packaging alone were not sufficient to prevent the growth and toxin production of clostridium botulinum type $\mathrm{E}$ without a fail-safe method to maintain the storage temperature at $0^{\circ} \mathrm{C}$.

Garcia, Genigeorgis, and Lindroth (1987) innoculated fresh salmon fillets with a spore pool of 13 nonproteolytic strains of clostridium botulinum type B, E, and F at six levels, and incubated them at $1^{\circ}, 4^{\circ}, 8^{\circ}, 12^{\circ}$, and $30^{\circ} \mathrm{C}$ under modified atmospheres for 60 days. Vacuum packaging, $100 \%$ $\mathrm{CO}_{2}$, and $70 \% \mathrm{CO}_{2} / 30 \%$ air environments were studied. The investigators reported that the earliest time toxin was detected was at: 1) one day of storage at $30^{\circ} \mathrm{C}$ with an innoculum of $10^{0}$ to $10^{3}$ spores/fillet, 2) three to nine days of storage at $12^{\circ} \mathrm{C}$ with an innoculum of $10^{1}$ to $10^{3}$ spores/fillet, and 3 ) six to twelve days of storage at $8^{\circ} \mathrm{C}$ with an innoculum of $10^{1}$ to $10^{2}$ spores/fillet. Only the $B$ type toxin was detected in the toxic fillets. No toxin was detected in fillets under any modified atmosphere stored at $4^{\circ} \mathrm{C}$ for up to 60 days. Toxin detection coincided with spoilage at $30^{\circ} \mathrm{C}$, preceded spoilage at $8^{\circ} \mathrm{C}$ and $12^{\circ} \mathrm{C}$, and followed spoilage at $4^{\circ} \mathrm{C}$. Toxigenesis occurred earlier in 
the vacuum packaged salmon than under the $\mathrm{CO}_{2}$-enriched environment.

In 1987, Barnett et al. studied the effect on extension of refrigerated shelf-life of trout packaged in laminated high/low density semi-permeable polyethylene bags in the presence of a $\mathrm{CO}_{2}$-enriched atmosphere. The effectiveness of a $2.3 \%$ potassium sorbate dip on fish quality was also investigated. The investigators reported that the potassium sorbate dip limited bacterial growth but did not extend shelf-life. Storing the trout with or without the potassium sorbate dip did not appear to suppress the development of oxidative rancidity as measured by the Thiobarbituric Acid test. The composition of the headspace gas changed during storage. The concentration of $\mathrm{CO}_{2}$ decreased while the concentration of oxygen increased. It was assumed that most of the reduction in $\mathrm{CO}_{2}$ between the initial sampling and the 20 th day of storage was the result of its transmission across the walls of the plastic bags and to a lesser extent due to the absorption of $\mathrm{CO}_{2}$ into the flesh of the trout. Control samples were spoiled by the 12th day of storage while the trout samples stored in the modified atmosphere remained acceptable until the 20th day. The authors concluded that the refrigerated shelf-life of fresh trout could be doubled from 10 to 20 days when held in a semipermeable type package in the presence of a $\mathrm{CO}_{2}$-enriched atmosphere.

stier et al. (1981) studied the potential for growth 
and toxin production of clostridium botulinum in salmon fillets held under modified atmosphere (MA). King salmon fillets and sandwiches (two samples placed stacked skin to flesh) were inoculated with $4 \times 10^{4} / \mathrm{mlof}$ types $A$ and $B$ or type $\mathrm{E}$ spores, or type $\mathrm{E}$ vegetative cell suspensions. Innoculated salmon samples were placed onto trays and covered with $0.005-0.006 "$ thick polyvinyl chloride (PVC). Half of the samples from each inoculation variable were then heat sealed in $4 \mathrm{ml}$ high density polyethylene-nylon-surlyn. Bags were evacuated using a syringe and back flushed with $60 \% \mathrm{CO}_{2}, 248 \mathrm{O} 2$, and $15 \% \mathrm{~N} 2$. Samples were incubated at $22.2^{\circ}$ $\mathrm{C}$ and $4.4^{\circ} \mathrm{C}$.

Results showed that all inoculated samples stored at $22.2^{\circ} \mathrm{C}$ became toxic within three days, regardless of inoculum type, type of fillet, or storage atmosphere. At $4.4^{\circ} \mathrm{C}$, there was no toxin production in any of the samples up to 57 days of storage, although samples had completely deteriorated.

At $4.4^{\circ} \mathrm{C}$, there was a distinct difference in acceptability between the samples held in air and the samples held under MA. The air-held samples had spoiled after six days from an organoleptic standpoint. Samples were discolored and had decomposition odors. There was also evidence of gross bacterial growth. The fillets held under MA for the same period of time had no degradation in appearance. At day eight, MA samples began to show signs of discoloration without any bacterial off-odors. By day 
twelve the MA fillets were determined to be unacceptable. The investigators concluded that $4.4^{\circ} \mathrm{C}$ storage effectively inhibited outgrowth and toxin production of the clostridium botulinum strains tested. The natural microflora and enzymes rendered salmon stored in an MA at $4.4^{\circ} \mathrm{C}$ inedible before toxin could be produced.

Baker and Genigeorgis (1989) conducted challenge tests on 51 sous-vide products, including fish. Salmonella, Iisteria, and clostridium botulinum types $E$ and nonproteolytic type B cultures were used as the inoculum. Samples were inoculated before and after thermal processing. Inoculated samples were placed into latex finger cots and sandwiched between rice layers in order to minimize heat transfer differences between products. Then the samples were vacuum packaged at $-950 \mathrm{~mm} \mathrm{Hg}$, inspected for leakage, and chilled to $1-2^{\circ} \mathrm{C}$. Packages were cooked in a circulating water bath at $60.1^{\circ} \mathrm{C}$ for 12 minutes. Thermocuples were used to monitor internal temperatures.

Results showed that an 8-minute hold time was sufficient to cause $>8$ decimal reduction regardless of the product being tested. Listeria was more heat resistent. Greater than 6.72 decimal reduction was achieved with a 12.4-15.0 minute come-up time and a 12 minute cooking time. Products which were first cooked, then inoculated, vacuum packaged, and incubated became toxic in advance of products which were inoculated prior to cooking. Type E toxin was most prevalent in the sous-vide products inoculated after 
thermal processing with a spore pool containing both type $\mathrm{E}$ and non-proteolytic type B strains. Samples (2/50) stored at $4^{\circ} \mathrm{C}$ became toxic at 35 days.

New generation refrigerated foods are an emerging category of products designed to satisfy a multitude of consumer demands (Baker \& Genigeorgis, 1989). Modified atmosphere storage has great potential for extending the shelf-life and controlling the growth of food pathogens at refrigerated temperatures (Hintlian \& Hotchkiss, 1986).

However, MA packaging must be used in conjunction with good manufacturing practices and proper post-processing chilling and storage temperatures in order to be an effective method to extend shelf-life and guarantee product safety (Baker \& Genigeorgis, 1989).

\section{Summary of Literature Review}

Fresh Norwegian salmon (Salmo salar) fillets arrive at Culinary Brands, Inc. facility skinless and boneless, stored at $36^{\circ} \mathrm{F}$. The fillets are carefully hand trimmed into sixounce (5.8-6.2 oz.) portions and tumbled in a sodium tripolyphosphate solution with ice and salt.

The fillets are vacuum packaged and heat processed in a convection oven using moisture-saturated air. After heat processing, the fillets are chilled in an ice water bath, then stored in the refrigerator until transport.

After processing is complete, total plate counts must be less than 1,000/gram, and coliform counts must be less 


\section{than 1/gram.}

Fish can spoil via microbiological, chemical, and physical modes. The development of oxidative rancidity and microorganism growth are significant causes of degradation in fresh fish. The microorganisms present in fish usually occur on the surface slime on the gills and in the intestines. The muscle is sterile. Microorganisms commonly associated with fish spoilage include Pseudomonas, Proteus, Aeromonas, Achromobacter, Micrococcus, Vibrio, and Clostridium, with Pseudomonas and Pseudomonas-like bacteria being predominant. There is special concern with regard to clostridium types $B$, and $E$ in fish that has not been sufficiently heat processed.

one of the most important factors that regulates growth of microorganisms is temperature. Every organism has a minimum, optimum, and maximum temperature at which it will grow. Because many marine fish and other creatures live in very cold temperatures in the sea, psychrophilic organisms are commonly found in fish and seafood. Psychrophiles are organisms which can grow as low as $-15^{\circ} \mathrm{C}$.

The atmosphere of the environment surrounding a food may determine the types of microorganisms that become dominant. Modified atmosphere and vacuum packaging extend shelf-life of refrigerated fresh foods by reducing the surface redox potential and changing the atmosphere within the package. The spoilage pattern becomes dominated by slow growth of facultative anaerobes resulting in discolorations. 
The primary substrate for bacterial growth and the main source of spoilage products is the dissolved material in the muscle. It is hypothesized that in fish, amino acids become the primary substrate since carbohydrate content is low. The sulfur-containing compounds produced as breakdown products are capable of producing objectionable odors, such as rotten egg odor and a musty sourness.

Trimethylamine oxide has also been implicated in the spoilage of fresh and frozen fish. Many Gram-negative psychrotrophic bacteria are capable of producing trimethylamine (TMA) from this enzyme. TMA is a volatile compound which may be responsible for some of the fishy odor encountered during the spoilage of fish.

Alterations in color are one of the primary chemical changes that can occur in spoiling and stored fish and seafood. Color is important because it is the first characteristic noted by a consumer.

The carotenoids are a group of pigments responsible for yellow, orange, and red colors that occcur in fish and seafood, including salmon. Astaxanthin is perhaps the major pigment in seafood and is responsible for the color of salmon. This compound tends to be very unstable. The carotenoids can act as a substrate for lypoxygenase, an enzyme endogenous to fish. However, this enzyme is heat labile.

Lipid oxidation is a major cause of spoilage in fish muscle. Most fish oils occur as triglycerides and have a 
large proportion of unsaturated fatty acids. Although the importance of lipid oxidation has been established, the mechanisms of the process are still not well understood. It is known that certain metals, high temperatures, peroxides, level of oxygen pressure, and some wavelengths of light catalyze the oxidative process. Factors which inhibit oxidation are metal sequesterants, freezing and refrigeration, antioxidants, inert gas and vacuum packaging, blanching, and hydrogenation of fatty acids.

The most common objective test used to follow lipid oxidation in foods is the Thiobarbituric Acid (TBA) test. TBA values of four and greater have been shown to be indicative of an unacceptably rancid product. There appears to be a rapid decline in TBA values as the bacterial population increases.

As previously mentioned, trimethylamine (TMA) is a volatile compound that is an end product of the reduction of trimethlamine oxide (TMAO). This reaction occurs after the death of the fish and is thought to be the main metabolic pathway for nitrogen elimination in elasmobranchs.

Two enzymes are considered to be responsible for the reduction of TMAO to TMA. These are endogenous enzymes in fish and exogenous enzymes produced by certain bacteria during spoilage. TMA formation has been reported to be found mostly in the dark muscle of fish.

- TMA level is currently used as an indicator of general fish spoilage. The fishy odor of spoilage is produced when 
TMA reacts with fat in the muscle of fish. It has been suggested that TMA levels between $5 \mathrm{mg}$ and $10 \mathrm{mg} / 100 \mathrm{gram}$ fish tissue be considered as the maximum allowable levels in international trading. In addition to TMA, there are other compounas produced during the spoilage of fish, including dimethylamine, ammonia, and formaldehyde.

Aside from deterioration by microoganisms and oxidative rancidity, the most conspicuous physical change that affects fish quality is an alteration in textural integrity. Toughening is a major problem in frozen-stored fish and is thought to result from a change in the structural proteins, actin and myosin. There is a decrease in the amount of soluble, heat-coagulable protein in fish cold-stored for extended periods of time. These proteins are saltextractable and the degree of extractability reflects denaturation and aggregation of the proteins. The property of salt-extractability has been termed extractable protein nitrogen.

Water-holding capacity describes the water retention of muscle foods. Water binding potential (WBP) and expressible moisutre (EM) are two methods commonly used to measure this property. WBP tends to be $\mathrm{PH}$ dependent while EM does not.

There are three basic types of flexible packaging materials used for foods: films, laminates, and bags or pouches. In addition, many packaging systems have been developed to suit the specific shelf-life requirements of a specific product. For instance, sous-vide products are 
vacuum packaged in Cryovac's 640 low density polethylene. vacuum packaging and modified atmospheres using carbon dioxide, nitrogen and oxygen mixtures are used to extend shelf-life of refrigerated foods. Carbon dioxide selectively inhibits certain microorganisms; however, this process is not well-understood. Nitrogen is used to overcome extreme exudation and distortion caused by some vacuum packaging techniques. oxygen is necessary to maintain color and odor.

The use of modified atmosphere packaging has proven to be successful in extending the shelf-life of many fresh and processed perishable foods. However, the application of modified atmosphere conditions cannot be used to eliminate the risk from microbial hazards. Modified atmosphere packaging must be used in conjunction with good manufacturing practices and proper post-processing chilling and storage temperatures in order to be an effective method to extend shelf-life and guarantee product safety. 
CHAPTER 2

JOURNAL ARTICLE 


\begin{abstract}
Author's Title Page
QUANTIFICATION OF THE PHYSICAL, CHEMICAL, AND SENSORY MODES OF DETERIORATION IN SOUS-VIDE PROCESSED SALMON
\end{abstract}

\author{
Beth Gittleson, Miriam Saltmarch, Peter Cocotas, \\ and Lucy McProud \\ Department of Nutrition and Food Science \\ San Jose State University \\ One Washington Square \\ San Jose, California 95192
}

For ail correspondence, please contact Miriam Saltmarch, Department of Nutrition and Food Science, San Jose State University, one Washington Square, San Jose, California $95192,408-924-3118$.

RUNNING HEAD: SHELF-LIFE OF SOUS-VIDE SALMON 
ABSTRACT

Commercially processed sous-vide salmon was stored between $0^{\circ}$ and $4^{\circ} \mathrm{C}$ for 12 weeks to quantify various possible physical, chemical, and sensory modes of deterioration. Two types of packages were studied: 1) a two-web coextrusion using nylon/ethyl vinyl alcohol (EVOH)/linear low density polyethylene (LLDPE) as the forming layer and nylon/ polyvinylidene chloride (PVDC)/LLDPE as the non-forming web and 2) a nylon/LLDPE pouch. Drip volume of the nylon/LLDPE samples increased at a rate about one and one half times that of the PVDC/EVOH samples. Total nitrogen concentration in the total drip volume/fillet increased similarly for both package types. Non-protein concentration in the total drip/fillet increased in the nylon/LLDPE samples at a rate trice that of the PVDC/EVOH samples while non-protein nitrogen concentration in the nylon/LLDPE samples increased at a rate about one and a half times that of the PVDC/EVOH samples. Thiobarbituric Acid (TBA) assays indicated increasing values during storage, but did not indicate rancidity. Sensory evaluation results showed that the salmon was acceptable up through 12 weeks of storage. 
INTRODUCTION

Extending shelf-life of refrigerated foods is a major concern of the food industry so many alternatives are currently being investigated. One of the more favorable approaches is packaging. Sous-vide, a French term for "under vacuum," describes a sophisticated technique whereby freshly prepared foods are vacuum sealed into individual packages and subsequently pasteurized to destroy all vegetative pathogens (Kramer, 1988). Because the food is cooked in the package, all natural juices, product weight, and portion size are preserved (Anonymous, 1988). In addition, flavor, freshness, color, and nutritive value are maintained (Kramer, 1988). Current refrigerated shelf-life of sous-vide salmon is microbiologically stable when stored at $34^{\circ} \mathrm{F}$ or below. These low storage temperatures inhibit growth of pathogenic microorganisms.

For the foodservice operator, sous-vide offers increased haute cuisine menu selection and skilled labor reduction because preparation is simplified. The extended shelf-life (compared to fresh fish) minimizes loss and waste (Swientek, 1989).

However, there is still concern regarding the safety of foods packaged via vacuum and modified atmosphere which have not received sufficient heat treatment to yield a shelfstable product (Baker and Genigeorgis, 1989). Since the process of sous-vide is a relatively new concept, there exists a general defecit of information about the safe 
shelf-lives of these types of products. At the present time, the microbiological stability of sous-vide products is under intense scrutiny, however, the physical, chemical, and sensory modes of degradation have not yet been addressed. Numerous investigators (Abrahamsson et al., 1966; Anderson, 1983; Barnett et al., 1987; Garcia et al.,; Post et al., 1985; Stier et al., 1981) have studied vacuum and modified atmosphere packaged raw fish. While these studies provide valuable information regarding the stability of non-heattreated $\mathrm{fish}$, the deteriorative mechanisms of pasteurized vacuum packaged fish still remain to be evaluated.

Baker and Genigeorgis (1989) conducted challenge tests using 51 sous-vide products, including fish. Samples were innoculated before and after thermal processing $\left(60^{\circ} \mathrm{C}\right.$ for 12 minutes with come-up times ranging from 13 to 20 minutes) with Salmonella and Listeria cultures and spores of nonproteolytic clostridium botulinum types $B$ and $E$. This was the first stuay conducted thus far on sous-yide products. In addition to studies on microbiological stability, investigations regarding the physical, chemical, and sensory stability of these products are also necessary in order to accurately predict shelf-lives. Establishing these critical factors will dramatically facilitate market expansion for "state-of-the-art" third generation sous-vide products and concurrently provide for a safe food of optimum quality. Therefore, the objectives of this study were to: 1) quantify various physical, chemical, and sensory modes of 
deterioration in sous-vide processed salmon; 2) determine shelf-life endpoints based upon each mode of deterioration evaluated; and 3) evaluate the relative influence of two types of packaging materials on the rates of deterioration. 
MATERIALS \& METHODS

Materials

Commercially processed sous-vide Norwegian salmon (Salmo salar) fillets $(n=100)$ were obtained locally. Each salmon fillet weighed approximately 5.8-6.2 oz and had been treated with a $1.48 \%$ sodium tripolyphosphate and salt solution. Half of the samples were packaged in a two-web system with a) nylon/polyvinylidene chloride (PVDC)/linear low density polyethylene (LLDPE) as the non-forming layer and b) nylon/ ethyl vinyl alcohol (EVOH)/LLDPE as the forming layer. The remaining half were packaged in a pre-formed pouch made of nylon/LLDPE. Permeability tests (ASTM, 1981) conducted on the films revealed that overall oxygen transmission rate for the PVDC/nylon/EVOH/LLDPE package was approximately 0.055 $\mathrm{cc} / 100 \mathrm{sq}$ in/24 hrs/1 ATM oxygen $/ 5^{\circ} \mathrm{C}$ (average of the permeabilities for both webs) and for the nylon/LLDPE package was approximately $0.6 \mathrm{cc} / 100 \mathrm{sq}$ in/24 hrs/1 ATM . oxygeñ $/ 5^{\circ} \mathrm{C}$. The tests were conducted using a Mocon oxtran II at $5^{\circ} \mathrm{C}$ and $0 \%$ relative humidity with a $100 \%$ environment on one side of the film and $0 \%$ oxygen on the other side. Total package oxygen transmission rates of the PVDC/nYlon/EVOH/LLDPE and the nylon/LLDPE packages were calculated to be $0.0172 \mathrm{cc} /$ package/ $24 \mathrm{hrs} / 5^{\circ} \mathrm{C}$ and 0.470 cc/package $/ 24 \mathrm{hrs} / 5^{\circ} \mathrm{C}$, respectively. Experimental Design

All samples were stored under refrigerated conditions for 12 weeks. Temperature was maintained at $0-4^{\circ} \mathrm{C}$ by 
packing ice around the samples which were stored in a large, fully enclosed styrofoam container. Three samples from each package treatment were pulled from storage weekly and used for chemical, physical, and microbiological analyses. Chemical analyses included evaluation of lipid oxidation, color changes, and nitrogen composition in the drip. Lipid oxidation evaluations were conducted bi-weekly. Physical analyses included measurement of texture and drip loss. Microbiological assays included quantification of total psychrophiles, total anaerobes/facultatives, Lactobacilli, and yeasts. Two additional samples from each package treatment were pulled weekly and used for sensory evaluations. All initial analyses were conducted on day six of the study for convenience purposes.

\section{Package Integrity Evaluation}

The package integrity of each packaged fillet was inspected prior to conducting the physical, chemical, and microbiological assays using a Multivac vacuum chamber! sealer. Packages were placed into the chamber one at a time. A 30" vacuum was pulled inside the chamber. Each package was carefully monitored for the expansion of air bubbles within the package. As the vacuum was released, the air bubbles decreased in size. The level of vacuum at which point the bubbles no longer became smaller was determined to be the level of vacuum remaining in the sealed package. coloir Analyses

The Hunter Color Difference Meter was used to follow 
color changes occurring in the salmon fillets. Initial. measurements were conducted on every salmon sample so that each sample served as its own control. It was necessary to measure color through the package in order to preserve package integrity.

The Hunter Color Meter was standardized according to manual instructions. A pale coral/salmon colored tile was used to calibrate $L, a$, and $b$ values to $67.4,20.6$, and 13.5, respectively.

$I, a$, and $b$ values were obtained for each sample analyzed. Because each sample served as its own control, the amount of change in these values was calculated by subtracting values obtained during the study from those values obtained at the initial evaluation.

Texture Measurements

The Instron Universal Testing Machine using the WarnerBratzler shear blade was utilized to measure textural changes (Instron corporation, 1972). A Ginaca pineapple core device was used to core a sample $3 \mathrm{~cm}$ in diameter from the center of the salmon fillet. The sample was oriented so that the shearing blade sheared the salmon flesh through the cross-sectional area. The shear area was determined to be $7.065 \mathrm{sq} \mathrm{cm}$.

Cross-head and paper speeds were set at 100 millimeters per minute. A baseline measurement (reflecting friction of the shear device) was run prior to evaluating the salmon samples. This frictional value was subtracted from the 
total peak height in order to accurately calculate shear force. Measurements were expressed in grams force/sq cm. Drip Loss Measurements

The amount of drip lost from each salmon fillet was obtained by volume measurement in milliliters (ml). A small hole was cut at the corner of each package. Fluid was expelled using gravity and by moving the salmon sample around within the package. No direct pressure was exerted on the sample itself. Fluid was collected into a ten $\mathrm{ml}$ graduated cylinder and the volume recorded. The cylinder was then washed with a known volume of distilled water to remove any remaining drip. The dilution factor (DF) was recorded for each sample of drip and used later in determining nitrogen composition of that sample. Drip samples were stored frozen in test tubes (2-3 days) until analyses for nitrogen were conducted.

Lipid Oxidation Assays

Iipid oxidation was measured using the Thiobarbituric Acid (TBA) distillation method (Tarladgis, Watts, Younathan, and Dugan, 1960). TBA values were calculated for each sample tested and represented $\mathrm{mg}$ malonaldehyde/1000 gm sample. Percent recovery was assumed to remain constant at $100 \%$.

Nitrogen Composition of the Drip Total nitrogen ( $\mathrm{mg} / \mathrm{ml})$ in the drip and total nitrogen (mg) per total drip volume/fillet were estimated using the Kjeldahl distillation method (AOAC, 1980). For each sample, 
five to eight $\mathrm{ml}$ of drip were measured into a flask using a graduated cylinder. The cylinder was washed with a few $\mathrm{ml}$ of distilled water to remove any remaining drip. Three reagent blanks were prepared for each analysis.

Samples and blanks were digested and distilled. Approximately $50 \mathrm{ml}$ of distillate was titrated against 0.10 $\mathrm{N}$ hydrochloric acid to the grey endpoint. Amount of nitrogen $(\mathrm{mg} / \mathrm{ml})$ was calculated as follows:

$\frac{(\mathrm{ml} \text { sample }-\mathrm{ml} \text { blank) } \times \mathrm{N} \mathrm{HCl} \times 14.007 \times \mathrm{DF}}{\text { volume of sample (ml) } \times 1000}$

Protein nitrogen in the drip was estimated using the Kjeldahl distillation method (AOAC, 1980). Protein in the drip was precipitated using the method of Bhatty and Finlayson (1973). Six to nine ml of drip from each sample tested were measured into a $250 \mathrm{ml}$ beaker using a graduated cylinder. Forty $m l$ of a $5 \%$ trichloroacetic acid (TCA) solution were added to the drip, reserving a portion to wash the graduated cylinder. A $5 \% \mathrm{TCA}$ solution was utilized because non-protein nitrogen has been defined as any nitrogenous constituents not precipitable by $5 \%$ TCA (Spinelli and Dassow, 1982). The beaker containing the drip/TCA mixture was put into a Precision Shaker Bath and taped into place to prevent unecessary jostling. The mixture was agitated at room temperature for one hour at 120 oscillations per minute.

The mixture was subsequently filtered through Whatman filter paper, the filtrate discarded, and the protein 
precipitate along with the filter paper were analyzed for protein nitrogen. Protein nitrogen (mg/ml drip) and total protein nitrogen (mg) per total drip volume/fillet were calculated using the above equation.

Non-protein nitrogen (mg/ml drip) was calculated indirectly by subtracting the protein nitrogen from the total nitrogen for the same sample. Total non-protein nitrogen (mg) per total drip volume/fillet was also calculated using the same methodology.

Microbiology

Microbiological analyses were conducted to assure that samples with counts of organisms were not used in calculating mean values of physical or chemical data if the values for that sample were inconsistent with values for the other samples.

Packages were aseptically opened using alcohol to cleanse the surface and an alcohol-dipped and flamed knife to cut the package open. An eleven gram sample of salmon was weighed and put into $99 \mathrm{ml}$ of sterile water diluent. This constituted a 10-fold dilution. No additional dilutions were made. Each sample was blenderized for 30 seconds in a waring blender. A one $\mathrm{ml}$ aliquot of the mixture was pipetted into a sterile petri plate. All plates for all analyses were poured in duplicate using the pourplate technique (Banwart, 1981).

- Anaerobic/facultative organisms were grown on plate count agar (PCA) and stored inverted at $4^{\circ} \mathrm{C}$ for three days. 
The BBL Gaspak Plus system was used to produce an anaerobic environment composed of carbon dioxide and nitrogen within a sealed chamber. Total psychrophiles were grown on PCA and stored inverted at $4^{\circ} \mathrm{C}$ for three days (APHA, 1984). The genus Lactobacillus was quantified on MRS agar (APHA, 1984) and stored inverted at $30^{\circ} \mathrm{C}$ for five days (Deible and Lindquist, 1981). Yeasts were enumerated on potato dextrose agar acidifed with sterile $10 \%$ tartaric acid and inverted storage at $25^{\circ} \mathrm{C}$ for five days (APHA, 1984). Sensory Evaluation

Quantitative Descriptive Analysis techniques (Stone and Sidel, 1985) were used to follow sensory changes in the salmon fillets. The attributes evaluated were color (pale pink to dark pink-orange), flakiness (none to very flaky), crumbliness/aryness (none to very crumbly), fishy odor (weak to strong), ammonia odor (weak to strong), and overall acceptability (unacceptable to acceptable). A semi-trained panel of four to seven judges used line scales with anchors to score each attribute. A vertical mark was made on the line where each judge perceived the intensity of the attribute in question. A control sample was provided at each evaluation so the panelists could evaluate the storage samples compared against the control; the control sample was not evaluated. The control was a fillet packaged in PVDC/nylon/EVOH/LLDPE that was within its current shelf-life of 21 days.

In the training sessions, the panelists agreed that the 
control should have the following scores (distance in cm from the left anchor): 6.6 for color, 11.4 for flakiness, 1.5 for crumbliness, 2.0 for fishiness, 0.8 for ammonia, and 12.2 for overall acceptability. These scores were marked permanently on the respective line scales to prevent the judges from changing the way they were evaluating the samples during the study.

Each scale was six inches $(15.2 \mathrm{~cm})$ in length and was divided into nine arbitrary units to make it easier for the panelists to evaluate the samples. Actual scores for each attribute were determined by measuring the distance in $\mathrm{cm}$ from the left anchor to the vertical mark made by the judge. Textural attributes were evaluated using a fork. No samples were consumed due to potential microbiological hazards which may have occurred at extended storage times.

Salmon fillets (still intact within the package) were simmered in hot water for ten minutes, then cut into $11 / 2^{*}$ x 1 1/2" pieces. Each piece was placed on a five inch white plastic plate coded with a three digit number. Judges evaluated the samples privately in booths.

Statistical Analyses

Regression equations were calculated from the physical and chemical data in order to obtain rate constants. student's $t$ distribution tests (Stone and sidel, 1985) were conducted on the physical and chemical data between package treatments to determine if any significant differences existed between the two package types. Duncan's Multiple 
Range and Heterogeneity of slopes Tests were performed on the sensory data using the statistical Analysis system (SAS) . 


\section{RESULTS \& DISCUSSION}

student's distribution tests were conducted on the physical and chemical data, but no significant differences were observed because the data showed great variability between triplicate analyses. However, general trends could be observed with regard to the physical and chemical changes occurring in the salmon fillets during storage. In addition, the data yielded calculated rate constants which had non-significant correlation coefficients due to data variability, but were reported as a basis of comparison between the two packaging materials.

Drip volume

As shown in Figure 1, drip volume (ml/fillet) increased during storage in both the PVDC/EVOH and the nylon/LLDPE packaged salmon fillets. Volume increased from about $4.0 \mathrm{ml}$ to $8.2 \mathrm{ml}$ in the PVDC/EVOH and from $2.2 \mathrm{ml}$ to $8.2 \mathrm{ml}$ in the nylon/LLDPE. Average maximum losses occurred at day 55 in the PVDC/EVOH samples and at day 76 in the nylon/LLDPE samples. There was a decrease in drip volume at days 83 and 90 in samples from both package treatments. Rate constants (ml/sample) were 0.044 for the PVDC/EVOH samples and 0.060 for the nylon/LLDPE samples. It appeared that drip volume increased at a greater rate in the nylon/LLDPE packaged fillets compared to the PVDC/EVOH packaged fillets, although final volumes at the end of the study were similar. The increase in drip volume indicated a decrease in the waterholding capacity of the fish muscle. It is also interesting 
to note that there was more space surrounding the fillet for the drip to exude in the nylon/LLDPE pouch package. The PVDC/EVOH package, in contrast, fit snuggly around the fillet, possibly inhibiting greater drip losses.

The fillets had been treated with sodium tripolyphosphate to improve moisture retention within the muscle. Since there was an increase in the drip volume during storage, the effect of this treatment appeared to be mediocre. However, no conclusions could be drawn about this behavior due to the fact that there were no untreated samples used in the study.

Shelf-life endpoint based upon drip loss was difficult to ascertain because there are no set parameters on what is unacceptable or acceptable. At day 69 of the study, the sensory panel began to make comments that the fish was dry and crumbly in texture. These comments continued for the remainder of the study. We can only suggest that 69 days be the shelf-life endpoint for drip loss based upon the sensory data collected.

Nitrogen Composition in the Drip

Data for samples with high microbial counts were reviewed for inconsistencies. One notable alteration in physical and chemical data was a substantial decrease in the nitrogen concentration of these samples. Therefore, these samples were not used in calculating rate constants. This condition could have been attributed to extensive proteolysis with subsequent utilization of breakdown 
products by the bacteria present. Liston (1982) reported that nearly all amino acids present in spoiling Pacific hake sharply decreased between four and seven days of storage on ice. Other investigators (Bramstedt, 1962; Shewan and Jones, 1957) found that bacterial action was associated with decreases in some amino acids (Liston, 1982).

Total nitrogen concentration in the drip (mg/ml) increased in the PVDC/EVOH samples from about $4.5 \mathrm{mg} / \mathrm{ml}$ to about $8.7 \mathrm{mg} / \mathrm{ml}$ by the end of the study (Fig. 2). In the nylon/LLDPE samples, total nitrogen increased from $6.3 \mathrm{mg} / \mathrm{ml}$ to about $8.4 \mathrm{mg} / \mathrm{ml}$ (Fig. 2). Rate constants ( $\mathrm{mg} \mathrm{N} / \mathrm{ml}$ ) are summarized in Table 1. It appeared that there was no difference in the rate of increase in total nitrogen concentration between the PVDC/EVOH and the nylon/LLDPE packaged salmon samples although the nitrogen concentration was lower initially in the PVDC/EVOH samples.

Gelling of the proteins on the fish surface was observed at day 55 in the fillets packaged in PVDC/EVOH and at 83 days in the nylon/LLDPE fillets. It was hypothesized that collagenous proteins, actin, or myosin were being released from the fish muscle. Therefore, shelf-life endpoint for sous-vide salmon based upon changes in nitrogen concentration in the drip was determined to be 55 days for the PVDC/EVOH samples and 83 days for the nylon/LLDPE samples.

Because nitrogen concentration in the drip and drip volume both increased under both package treatments, the 
implications of this should be acknowledged. Figure 3 shows the interaction when the concentration of total nitrogen lost from each sample is calculated based upon the total drip volume. The increases in nitrogen concentration and drip volume which occurred individually were magnified when their interaction was examined. Rate constants calculated for this increase were similar for both package treatments (Table 1).

Figure 4 shows the change in protein nitrogen concentration in the drip ( $\mathrm{mg} \mathrm{N} / \mathrm{ml}$ ) for the PVDC/EVOH and nylon/LLDPE samples. Protein nitrogen concentration increased in the PVDC/EVOH samples at a rate almost two times that of the nylon/IIDPE samples (Table 1). The increase in protein nitrogen concentration in the drip of the PVDC/EVOH packaged fillets indicated an increase in the release of soluble proteins from the fish muscle. The increase in protein nitrogen concentration in the nylon/LLDPE samples was so slight as to be negligible. Figure 5 depicts the changes in protein nitrogen concentration as a function of increasing drip volume. Rate constants (mg $\mathrm{N} /$ total drip volume) were calculated to be 0.190 for the PVDC/EVOH samples and 0.278 for the nylon/ LLDPE. The overall rate of loss of protein nitrogen was about one and a half times greater in the nylon/LLDPE samples. These data indicate that although the PVDC/EVOH packaged samples had a higher concentration of protein nitrogen per ml of drip, overall, the nylon/LLDPE samples 
lost more protein nitrogen because of greater drip losses. Non-protein nitrogen (NPN) concentration in the drip (mg $\mathrm{N} / \mathrm{ml}$ ) increased in the PVDC/EVOH samples from about 4.1 $\mathrm{mg} / \mathrm{ml}$ to $5.5 \mathrm{mg} / \mathrm{ml}$ and in the nylon/LLDPE samples from 3.2 $\mathrm{mg} / \mathrm{ml}$ to $6.2 \mathrm{mg} / \mathrm{ml}$ (Fig. 6). Rate constants (mg N/ml) are summarized in Table 1 . NPN concentration increased in the nylon/LLDPE samples at a rate twice that of the PVDC/EVOH samples. Figure 7 illustrates that the rate of NPN lost into the total drip volume in the nylon/LLDPE samples was twice that of the PVDC/EVOH samples, indicating that the increase in drip volume combined with the greater NPN concentration per $\mathrm{ml}$ of drip showed a much greater increase overall.

The sodium tripolyphosphate treatment could possibly have contributed to an increased nitrogen concentration in the drip. Love and Abel (1966) reported that degradation of myofibrils in fish muscle occurred in fish that were treated with sodium tripolyphosphate (Love, 1983). Love (1983) also stated that the texture of cooked fish muscle became soft and sloppy. The sodium tripolyphosphate and salt treatment is used in sous-vide salmon to improve moisture retention in the muscle; however, the proteins in the fish muscle cells may have been affected. Moisture loss nevertheless occurred in the fillets during storage.

Although nitrogen concentration increased during storage, the amount of the increase was only about 3 to 4 $\mathrm{mg} / \mathrm{ml}$ drip. Whether this change significantly altered the 
texture from an organoleptic standpoint is difficult to determine based upon the results of this study. Because gelling of the proteins on the fish surface was observed at day 55, it was hypothesized that collagenous proteins were being released from the fish muscle.

Lipid oxidation

Results of the lipid oxidation assays indicated that TBA values remained low and somewhat variable during storage. Fig. 8 shows the change in TBA values for both package treatments. Lipid oxidation occurred at a substantially greater rate in the fillets packaged without the EVOH barrier compared to those packaged with the barrier. Calculated rate constants (mg malonaldehyde/1000 gin sample) were 0.0088 and 0.030 for the PVDC/EVOH and the nylon/LLDPE samples, respectively.

The calculated permeability of the nylon/LLDPE package was about 23 times that of the PVDC/nYlon/EVOH/LLDPE package. The EVOH barrier appeared to demonstrate its effect on the rate of lipid oxidation, as measured by TBA value, in sous-vide salmon stored at an average temperature of $2.5^{\circ} \mathrm{C}$.

Although TBA numbers increased during storage, values still remained below a value of four, a TBA level generally considered as indicative of rancidity (Tarladgis et al., 1960). There was one exception, however; a PVDC/EVOH packaged sample was found to have a value of 8.22 at day 76 of the study. This sample was also found to be packaged in 
a vacuum of 24" compared with a vacuum of 28 " to 29 " measured in the other packages. It is also interesting to note that low TBA values $(0.52)$ were observed in two samples packaged in nylon/LIDPE at day 90 of the study that had microbiological activity. Other investigators, Unda, Molins, and Walker (1990) and Moerck and Ball (1974) have also reported decreasing TBA values with increasing bacterial spoilage.

There was some lipid oxidation occurring; however, there were several factors present that limited the mechanism, including low storage temperature, anaerobic environment, and the sodium tripolyphosphate treatment. Using a TBA endpoint of four, the shelf-life for sous-vide salmon based upon lipid oxidation was determined from the regression line, indicating a predicted shelf-life of 454 days for the PVDC/EVOH fillets and 140 days for the nylon/LLDPE fillets.

Instron Data

Instron measurements showed no significant changes during storage regardless of package type. Rate constants are shown in Table 1. The Instron measurements for the PVDC/EVOH and the nylon/LLDPE packaged salmon fillets showed great variability. This could have been attributed to variation that is generally seen in fish itself. Texture can be influenced by the size of the fish, with the bigger fish being more tough. We did not control for original fish size in this study. Although drip volume and nitrogen 
concentration in the drip both increased, it appeared that the texture, as measured by the Instron, did not reflect any toughening or softening during storage.

Because fish muscle is so delicate, it was difficult to orient the sample appropriately underneath the shear blade. It is possible that this difficulty affected the results. other devices attached to the Instron testing machine may have been more applicable, such as a penetrating rod in triplicate measurements for each sample. Data were determined not to be indicative of textural changes occurring in the fillets. Therefore, no shelf-life endpoint was determined.

Color Changes

Hunter Color Difference Meter I values slightly increased during storage in the nylon/LLDPE packaged fillets but did decrease in the PVDC/EVOH packaged samples. Rate constants for the amount of change were -0.046 for the PVDC/ EVOH samples and 0.005 for the nylon/LLDPE samples. In general, there were no trends seen for $L$ value during storage. Triplicate analyses indicated a high degree of variability, possibly due to measuring through the package material. In a study conducted by Nakayama and Yamamoto (1977), it was reported that there was no change in I values, measured at $\mathrm{Rd}$ value using the Gardner color Difference Meter, for frozen turbot, codfish, or shortspine thornyhead during storage at $-20^{\circ} \mathrm{C}$.

Rate constants for the amount of change in a values 
were -0.0175 for the PVDC/EVOH samples and 0.0150 for the nylon/ LLDPE samples. The rates were similar for both package treatments. No trend was observed.

Hunter color b values showed no trend. Rate constants for the amount of change were -0.0044 for the PVDC/EVOH samples and 0.0289 for the nylon/PVDC samples. The rate constants appeared to be very different based upon package type; however, there was a considerable amount of variability between triplicate measurements. No conclusions were drawn from this data. No shelf-life endpoints for color degradation based upon the Hunter Color Difference Meter were calculated. Microbiology

Microbiological data showed that total psychrophilic counts varied considerably during storage (Fig. 9). Initially, counts were zero organisms per gram of fish. By day 13, a plate containing too numerous microbes to count (TNTC) was discovered while the remaining plates contained zero psychrophiles. Counts per gram ranged from zero to 310 between weeks three and ten. At weeks 11 and 12 , zero growth was noted in the nylon/LIDPE samples. However, spotty growth was noted in the PVDC/EVOH samples. Because growth of Lactobacillus remained low and variable, plating was conducted bi-weekly. Counts per gram of fish ranged from zero to 85 in the nylon/LLDPE samples and from zero.to 20 in the PVDC/EVOH samples (Fig. 10). Anaerobic/ facultative growth remained low to non-existent in the 
PVDC/EVOH samples (Fig. 11). The highest growth was noted at day 13 (15 colonies/gram fish). During the last five weeks of storage zero growth was noted.

In the nylon/LLDPE samples, anerobic/facultative growth remained relatively low for the most part (Fig. 12). At day six, counts of $5 /$ gram fish and $10 /$ gram fish were enumerated on two separate samples. Subsequent plating showed zero growth for the following four weeks. At days 41 and 55, growth was TNTC on duplicate plates of a single sample. Counts per gram of fish were zero at weeks 8 through 12 . Yeast growth was virtually non-existent. One PVDC/EVOH sample was found to have growth of 5 colonies/gram fish at day 20. No other growth was observed through day 27 . A nylon/LLDPE sample was found to have 5 colonies/gram at day 90. Plating was discontinued for the remainder of the study except for a final plating at day 90. At this last evaluation, a nylon/LLDPE sample was found to have growth of 5 colonies/gram.

Sensory Evaluation

Color significantly changed with time in both the PVDC/ EVOH $(p<0.001)$ and nylon/LLDPE samples $(p<0.01)$, but there were no trends observed (Fig. 11). Panelists noted browning as early as day 20 of the study, indicating that the sousvide process itself may have produced some color changes in the salmon flesh that may have rendered it less "salmoncolored" and fresh-looking than a freshly cooked salmon fillet. 
Fishy aroma significantly changed with time in both the PVDC/EVOH and the nylon/LLDPE samples (Fig. 13). Upward trends were observed for both samples. See Table 3 for the slope of change during storage. The EVOH-protected samples had significantly less fishy aroma compared to the samples packaged without the EVOH barrier $(p<0.05)$. This difference may have been attributed to the fact that there was greater oxidation of lipids in the nylon/LLDPE samples and these end products may have reacted with trimethylamines to produce the fishy odor.

Although ammonia odor was evaluated, it was hypothesized that the panelists perceived fishy and ammonia odors as one in the same. Therefore, results for ammonia odor were not reported.

There were no significant changes in the PVDC/EVOH samples for flakiness or crumbliness; however, both attributes did significantly change with time in the nyionf LLDPE samples. No trends were observed for texture changes in either package treatment. Crumbliness and flakiness were negatively correlated $(p<0.01)$. Panelists first noted signs of dryness at day 69 and their comments continued for the remainder of the study.

There was a lot of fluctuation in overall acceptability scores for both the PVDC/EVOH and the nylon/LLDPE salmon fillets during storage (Fig. 14). The fluctuations could have been due to variability in the sensory panel between evaluations and in the salmon fillets themselves. It has 
been well documented that fish composition varies depending on the area of the fish being analyzed. It is possible that the significant variation in sensory scores reflected this phenomenon.

Heterogeneity of slopes Test indicated slopes of change to be 0.0270 for nylon/LLDPE samples and -0.0708 for the PVDC/EVOH samples for overall acceptability (Table 3). These slopes were significantly different $(p<0.10)$, with the EVOH-protected salmon fillets degrading at a greater rate.

overall acceptability was negatively correlated to fishy aroma $(p<0.01)$, indicating that as fishy aroma increased, acceptability decreased. Fishy aroma appeared to be the more sensitive sensory attribute in sous-vide salmon and, therefore, could be used as an indicator of $f$ ish quality.

Acceptability scores dropped at week ten due to the discovery of a spoiled PVDC/EVOH packaged sample. This sample was described as smelling like ocean mud, feces, blue-cheese, and a dirty diaper. However, it was not known at what point in time that particular sample actually spoiled. Acceptability values increased again at eleven and twelve weeks, indicating that the shelf-life of the PVDC/EVOH and nYIon/LLDPE samples appeared to be up through twelve weeks.

Additional sensory comments noted during the study included musty odor, curdy surface on the PVDC/EVOH samples, dirty-looking, slight buttery aroma, and sulfurish/skunky 
odor. 
SUMMARY \& CONCLUSIONS

The results of this study provide a clearer picture of the stability of sous-vide salmon during refrigerated storage. Changes which occurred included increased drip loss and an increase in nitrogenous components into the drip. In addition, lipid oxidation occurred at low levels but did not become significant. Fishy aroma was an important sensory attribute in determining the quality of the fillets. Based upon the sensory data, the salmon fillets were acceptable up through twelve weeks. These were the changes found to be the physical, chemical, and sensory deteriorative factors in sous-vide salmon that influenced its shelf-life.

The PVDC/nylon/EVOH/LLDPE package appeared to offer greater protection of the salmon fillets from drip loss, lipid oxidation, and production of fishy aroma than the nylon/LLDPE package. It is recommended that the PVDC/nylon/ EVOH/LLDPE package be utilized to store sous-vide salmon.

Since the sous-vide saimon is microbiologicallȳ stable when stored below $34^{\circ} \mathrm{F}$, the physical, chemical, and sensory modes of degradation become more important. Shelf-life endpoints were established based upon the major changes occurring during prolonged storage. The primary mode of degradation limiting shelf-life appeared to be loss of nitrogenous constituents into the drip. 
REFERENCES CITED

Abrahamsson, K., Gullmar, B., and Molin, N. 1966. The effect of temperature on toxin formation and toxin stability of clostridium botulinum type $e$ in different environments. J. Food Sci. 12: 385.

Anderson, D.C. 1983. Vacuum packaging of frozen and fresh fisheries products. Paper No. 153, presented at $43 \mathrm{rd}$ Annual Meeting of Inst. of Food Technologists, New Orleans, IA, June 19-22.

Anonymous. 1988. Package, precautions set sous-vide line apart. Food and Drug Packaging. 52(9): 3 .

AOAC, 1984. "Official Methods of Analysis," 14th ed. Association of Official Analytical Chemists, Washington, DC.

APHA, 1984. "Compendium of Methods for the Microbiological Examination of Foods," 2nd ed. American Public Health Association, Washington, DC.

ASTM, 1981. "Annual Book of ASTM Standards," Part 35. American Society for Testing and Materiais, Philadelphia, Pennsylvania.

Baker, D. A. and Genigeorgis, C. 1989. Microbiological risk assessment of refrigerated foods: The safety of sousvide products. Presented at Xth International symposium of the World Association of Veterinary Food Hygienists, Stockholm, Sweden, July 2-7.

Bhatty, R.S. and Finlayson, A.J. 1973. Extraction of nonprotein nitrogen from oilseed meals with different 
solvents. Cereal Chem. 50(3): 329 .

Banwart, G.J. 1981. "Basic Food Microbiology," abridged ed.

AVI Publishing Co., Inc., Westport, CT.

Barnett, H.J., Conrad, J.W., and Nelson, R.W. 1987. Use of

laminated high and low density polyethylene flexible

packaging to store trout (salmo gairdneri) in a

modified atmosphere. J. Food Prot. 50: 645.

Bramstedt, F. 1962. Amino acid composition of fresh $f i s h$ and

influence of storage and processing. "Fish in

Nutrition," E. Heen and R. Kreuzer (Eds.), p. 61.

Fishing News Lta., London. [In Liston, J. (1982) . Ch.

3. In "Chemistry and Biochemistry of Marine Food

Products," R.E. Martin, G.J. Flick, C.E. Hebard, D.R.

Ward (Eds.), p. 27. AVI Publishing Co., Westport, CT.]

Deibel, R.H. and Lindquist, J.A. 1981. "General Food

Microbiology Laboratory Manual," Burgess Publishing

Co., Minneapolis, MN.

Garcia, G.W., Genigeorgis, C., and Lindroth, S. 1987. Risk

of growth and toxin production by clostriaium botulinum nonproteolytic types $b, e$, and $f$ in salmon fillets

stored under modified atmospheres at low and abused

temperatures. J. Food Sci. 50: 330.

Instron corporation. 1972. Canton, MA

Kramer, I. June, 1988. Is it real or is it sous-vide?

Catering Today: 25.

Liston, J. 1982. Recent advances in the chemistry of iced fish spoilage. Ch. 3. In "Chemistry and Biochemistry of 
Marine Food Products," Martin, R.E., Flick, G.J., Hebard, C.E., and Ward, D.R. (Eds.), p. 27. AVI Publishing Co., westport, CT.

Love, M. 1984. Texture and the fragility of fish muscle cells. J. Tex. Stud. 14: 323 .

Love, R.M. and Abel, G. 1966. The effect of phosphate solutions on the denaturation of frozen cod muscle. $J$. Food Technol.: 1, 323. In J. Tex. Stud. (1984) 14: 323. Moerck, K.E. and Ball, Jr., H.R. 1974. Lipid oxidation in mechanically deboned chicken meat. J. Food Sci. 39: 876. In J. Food Sci. (1990) 55: 323.

Nakayama, T. and Yamamoto, M. 1977. Physical, chemical, and sensory evaluations of frozen-stored deboned (minced) fish flesh. J. Food Sci. 42: 900.

Post, I.S., Lee, D.A., Solberg, M., Furgang, D., Specchio, J., and Graham, C. 1985. Development of botulinal toxin and sensory deterioration during storage of vacuum and modified atmosphere packaged fish fillets. J. Food sci. 50: 990 .

Shewan, J.M. and Jones, N.R. 1957. Chemical changes occurring in cod muscle during chill storage and their possible use as objective indices of quality. J. Sci. Food Agric. 8: 491. [In Liston, J. (1982). "Chemistry and Biochemistry of Marine Food Products, "R.E. Martin, G.J. Flick, C.E. Hebard, D.R. Ward (Eds.), p. 27. AVI Publishing Co., Westport, CT.

stier, R.F., Bell, L., Ito, K.A., Shafer, B.D., Brown, I.A., 
Seeger, M.L., Allen, B.H., Porcuna, M.N., and Lerke, P.A. 1981. Effect of modified atmosphere storage on $c$. botulinum toxigenesis and the spoilage microflora of salmon fillets. J. Food Sci. 46: 1639.

Stone, H. and Sidel, J.L. 1985. "Sensory Evaluation Practices." Academic Press, Inc., orlando, FL.

Swientek, R.J. 1989. Sous-vide, refrigerated upscale food in a vacuum pouch. Food Proc. $50(6): 34$.

Tarladgis, B.G., Watts, B.M., Younathan, M.T., and Dugan, L. Jr. 1960. A distillation method for the quantitative determination of malonaldehyde in rancid foods. $J$. Amer. Chem. Soc. 37: 44 .

Unda, J.R., Molins, R.A., and Walker, H.W. 1990. Microbiological and some physical and chemical changes in vacuum-packaged beef steaks treated with combinations of potassium sorbate, phosphate, sodium chloride, and sodium acetake. J. Food Sci. 55: 323. 
ACKNOWLEDGEMENTS

The authors gratefully acknowledge Culinary Brands, Inc. for donating all the sous-vide salmon fillets for this study. The results of this study were presented at the Institute of Food Technologists annual meeting in Anaheim, California, 1990. 
Table 1. Rate Constants for Physical and Chemical Data

\begin{tabular}{|c|c|c|}
\hline \multirow[b]{2}{*}{$\begin{array}{l}\text { Physical or } \\
\text { Chemical Index }\end{array}$} & \multicolumn{2}{|c|}{ Rate Constant $\times 10^{-2}$} \\
\hline & PVDC/EVOH & nYIOn/IIDPE \\
\hline Drip Volume (ml/fillet) $)^{b}$ & 4.40 & 6.00 \\
\hline Total Nitrogen (mg $\mathrm{N} / \mathrm{ml}$ arip) ${ }^{\mathrm{b}}$ & 3.26 & 3.30 \\
\hline $\begin{array}{l}\text { Total Nitrogen in the Drip } \\
\text { Per Fillet (mg N/total drip } \\
\text { volume in filiet) }\end{array}$ & 75.00 & 80.00 \\
\hline Protein Nitrogen $\left(\mathrm{mg} / \mathrm{ml}\right.$ drip) ${ }^{b}$ & 1.30 & 0.80 \\
\hline $\begin{array}{l}\text { Protein Nitrogen in the Drip } \\
\text { Per Fillet (mg N/total drip } \\
\text { volume in fillet) }\end{array}$ & 19.00 & 27.80 \\
\hline $\begin{array}{l}\text { Non-Protein Nitrogen } b \\
(\mathrm{mg} \mathrm{N} / \mathrm{ml} \text { drip) }\end{array}$ & 1.65 & 3.05 \\
\hline $\begin{array}{l}\text { Non-Protein Nitrogen in the } \\
\text { Drip Per Fillet (mg } M / \text { total } \\
\text { drip volume in fillet) }\end{array}$ & 30.00 & 62.00 \\
\hline $\begin{array}{l}\text { TBA Number b } \\
\text { (mg malonaldehyde/1000 gm } \\
\text { sample) }\end{array}$ & 0.88 & 3.00 \\
\hline $\begin{array}{l}\text { Instron } \\
\text { Measurement } \\
(\mathrm{gm} \text { force/sq cm) }\end{array}$ & 19.50 & -7.50 \\
\hline I Hunter Value & -4.60 & 0.50 \\
\hline A Hunter Valueb & -1.75 & 1.50 \\
\hline B Hunter Value & -0.44 & 2.89 \\
\hline
\end{tabular}

a Negative sign denotes a decreasing rate constant. benotes no significant difference between package treatments at $\mathrm{p}<0.05$. 
Table 2. Shelf-Life Endpoints for Physical and Chemical Data

\begin{tabular}{|c|c|c|}
\hline \multirow[b]{2}{*}{$\begin{array}{l}\text { Physical or } \\
\text { Chemical Index }\end{array}$} & \multicolumn{2}{|c|}{ Shelf-life in Days } \\
\hline & PVDC/EVOH & nylon/LLDPE \\
\hline Drip Volume (ml/fillet) & 69 & 69 \\
\hline $\begin{array}{l}\text { Total Nitrogen in the Drip } \\
\text { Per Fillet (mg N/total drip } \\
\text { volume in fillet) }\end{array}$ & 55 & 55 \\
\hline $\begin{array}{l}\text { TBA Number }{ }^{a} \\
\text { (mg malonaldehyde/1000 gm } \\
\text { sample) }\end{array}$ & 454 & 140 \\
\hline $\begin{array}{l}\text { Instron }{ }^{b} \\
\text { Measurement } \\
(\mathrm{gm} \text { force/sq cm) }\end{array}$ & $---\infty$ & ---- \\
\hline L Hunter Value & --- & --- \\
\hline A Hunter Value & ---- & --- \\
\hline B Hunter Value & ---- & --- \\
\hline
\end{tabular}

andicates calculated shelf-life enapoint determined from the regression line and using a TBA number of 4 as the endpoint.

b

No shelf-life endpoint determinea because no treñas were observed in the data. 
Table 3. Slopes of Change with Time for Sensory Attributes ${ }^{a}$

\begin{tabular}{lcc}
\hline \multicolumn{1}{c}{ Attribute } & PVDC/EVOH & nYIon/LLDPE \\
\hline Degree of Color & -0.0092 & 0.0400 \\
Degree of Flakiness & -0.0001 & 0.1326 \\
Degree of Crumbliness & 0.0342 & -0.0247 \\
Degree of Fishy Aroma & 0.0679 & 0.0763 \\
$\begin{array}{l}\text { Degree of Overall } \\
\text { Acceptability }\end{array}$ & -0.0708 & 0.0270 \\
\hline
\end{tabular}

A negative slope denotes a decrease in the attribute with time. 


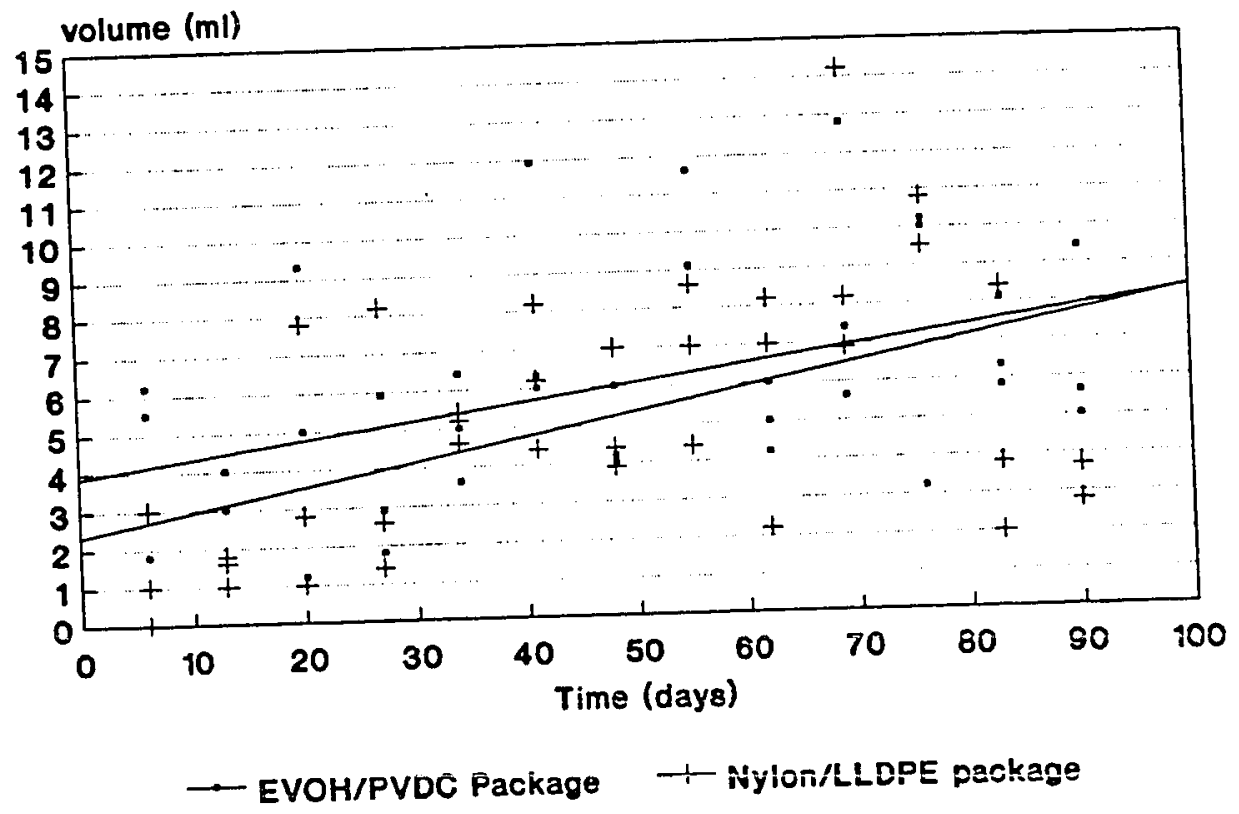

Figure 1. Changes in drip volume during storage. 


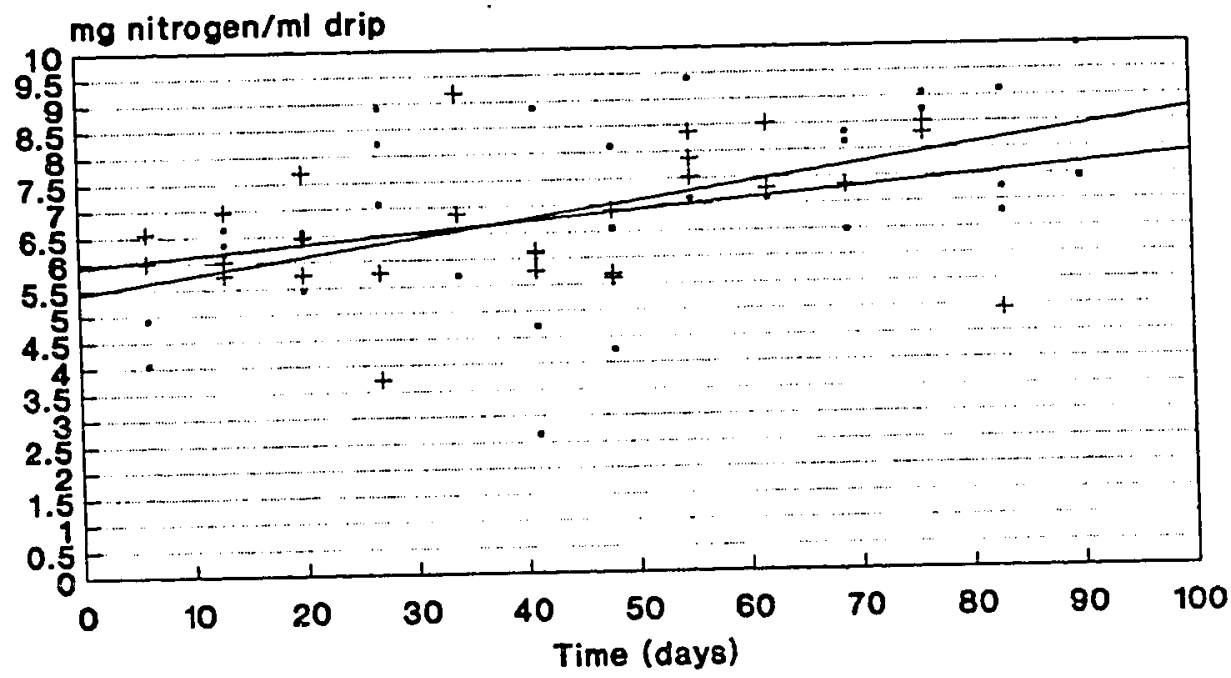

- EVOH/PVDC Package + Nylon/LLŨ̄E Package

Figure 2. Changes in total nitrogen concentration/ml drip during storage. 


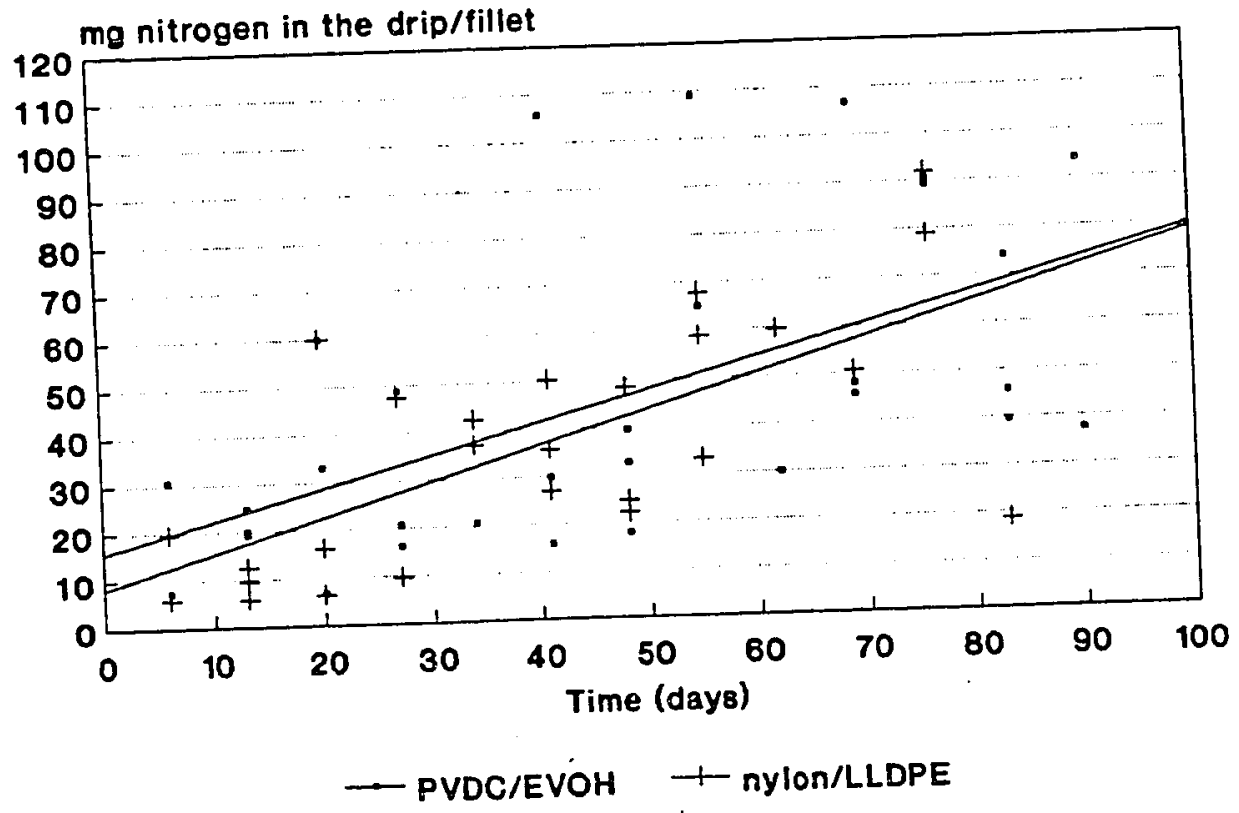

Figure 3. Changes in total nitrogen concentration in the total drip volume per fillet during storage. 


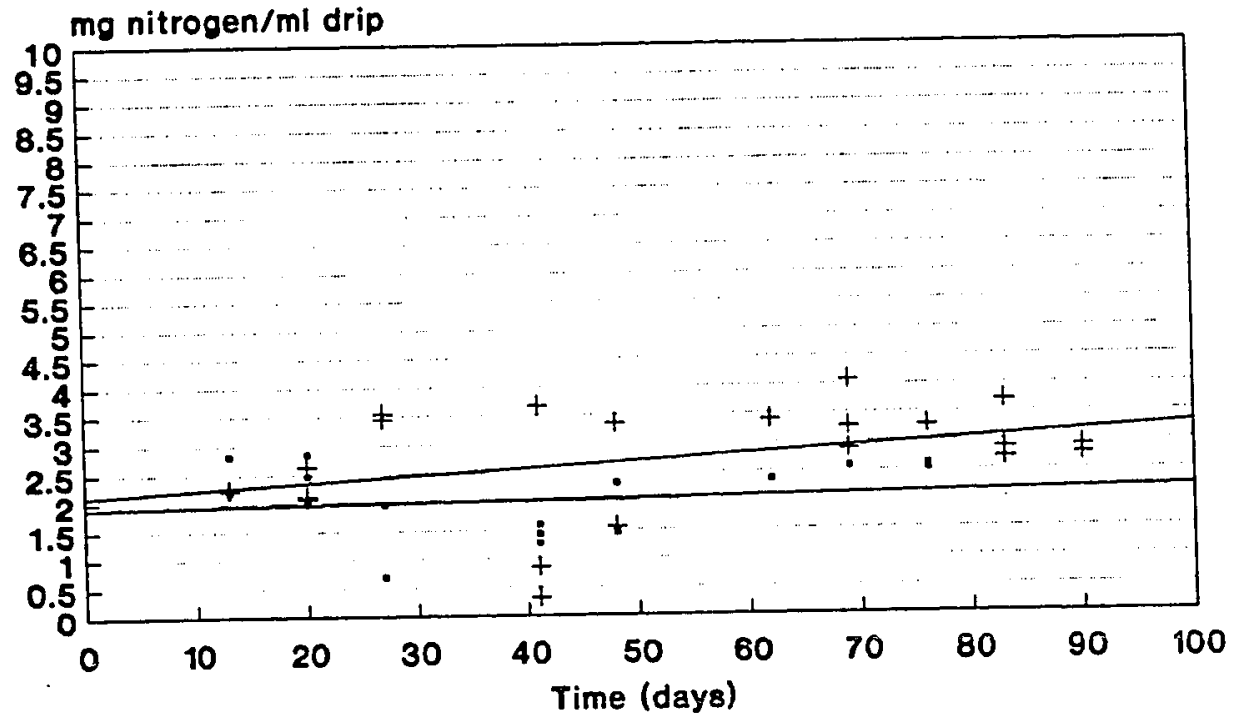

$\rightarrow$ Nylon/LLDPE Packăge T EVOH/PVDC Package

Figure 4. Changes in protein nitrogen concentration per ml drip during storage. 


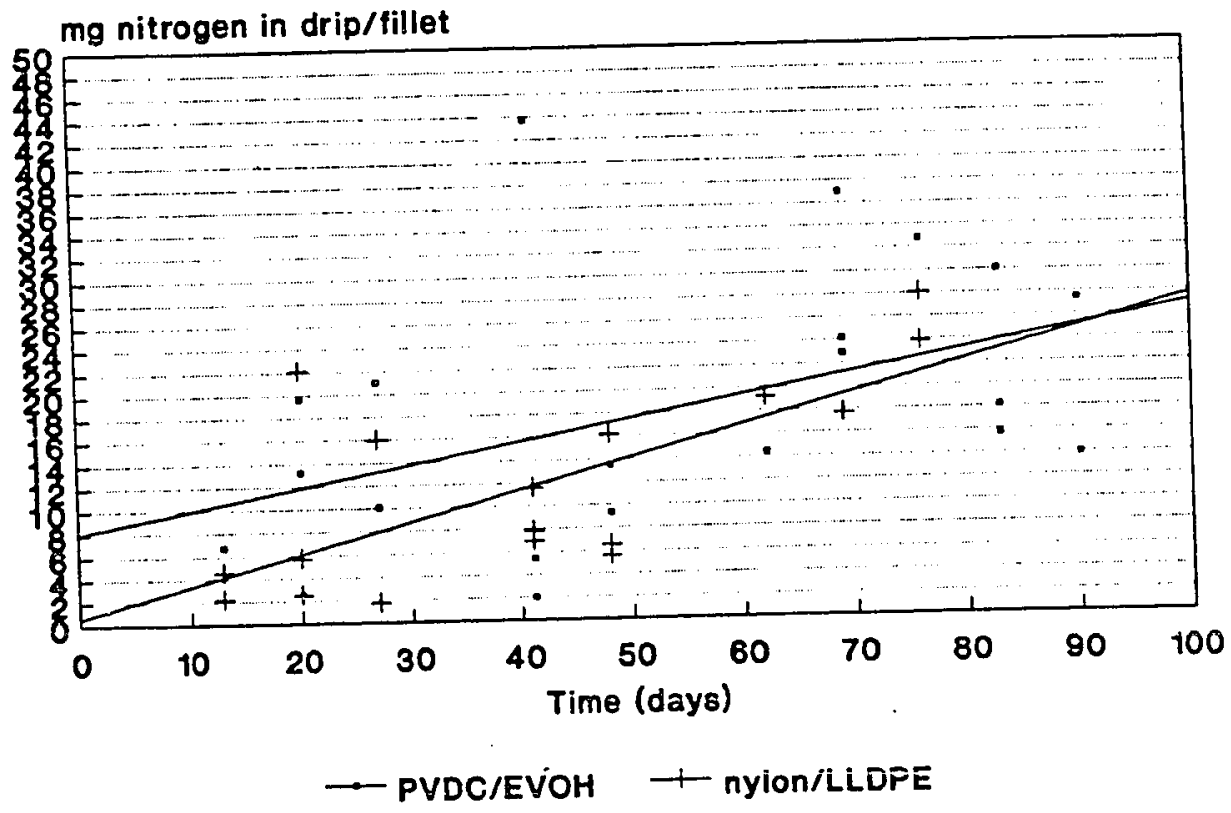

Figure 5. Changes in protein nitrogen concentration in the total drip volume per fillet during storage. 


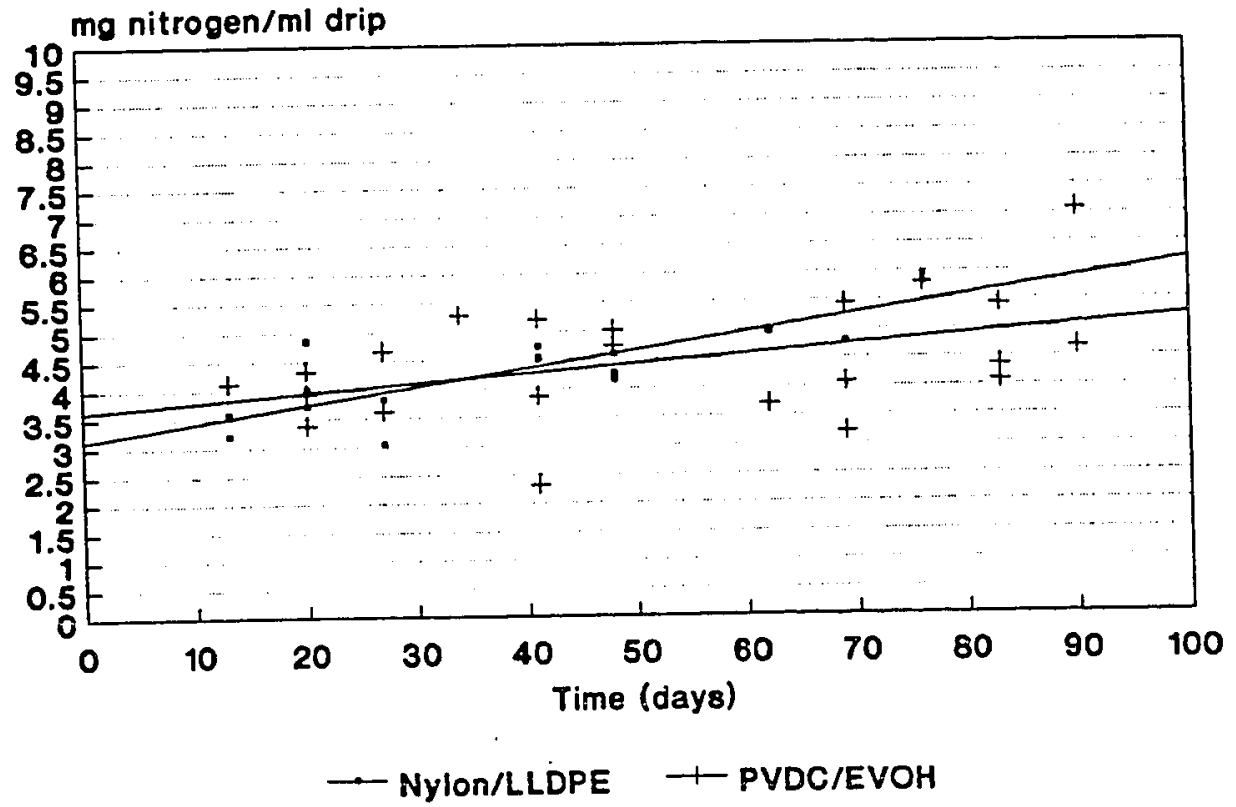

Figure 6. Changes in non-protein nitrogen concentration per ml drip during storage. 


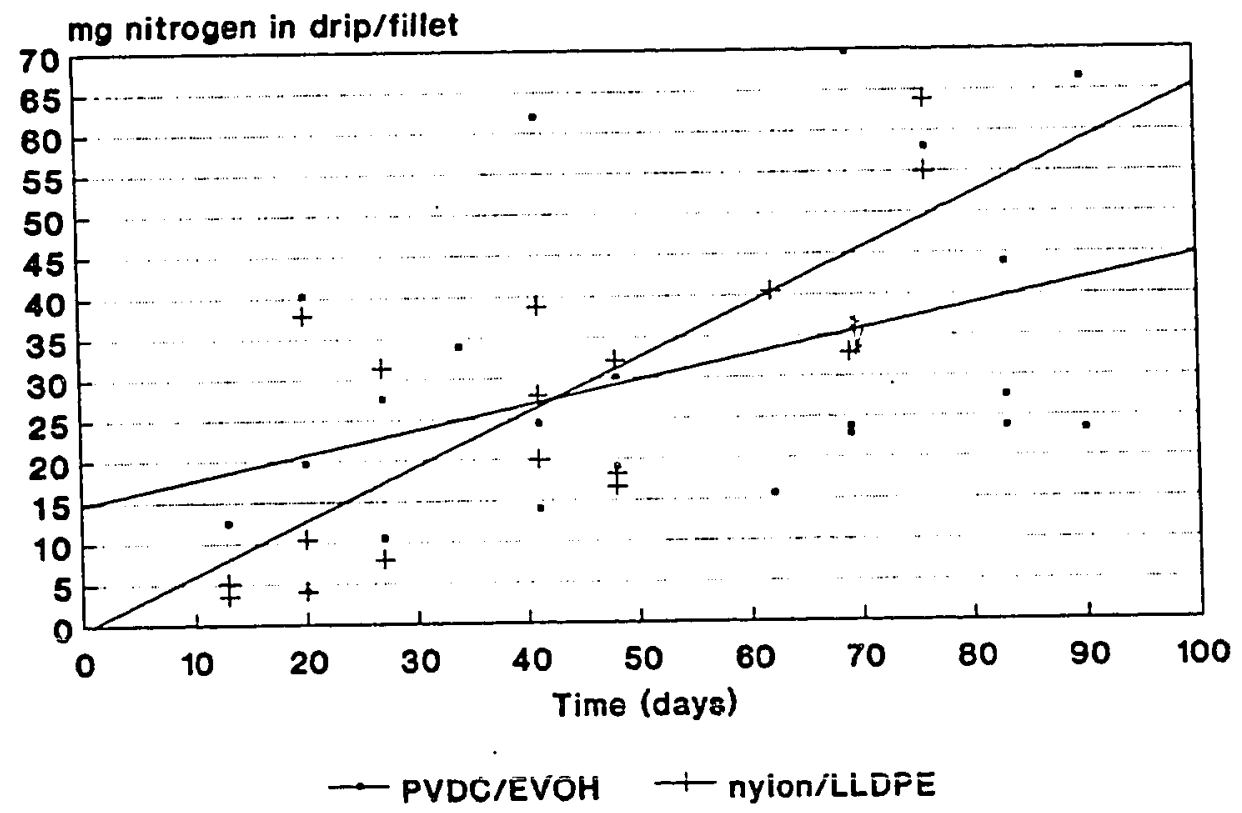

Figure 7. Changes in non-protein nitrogen concentration in the total drip volume per fillet during storage. 


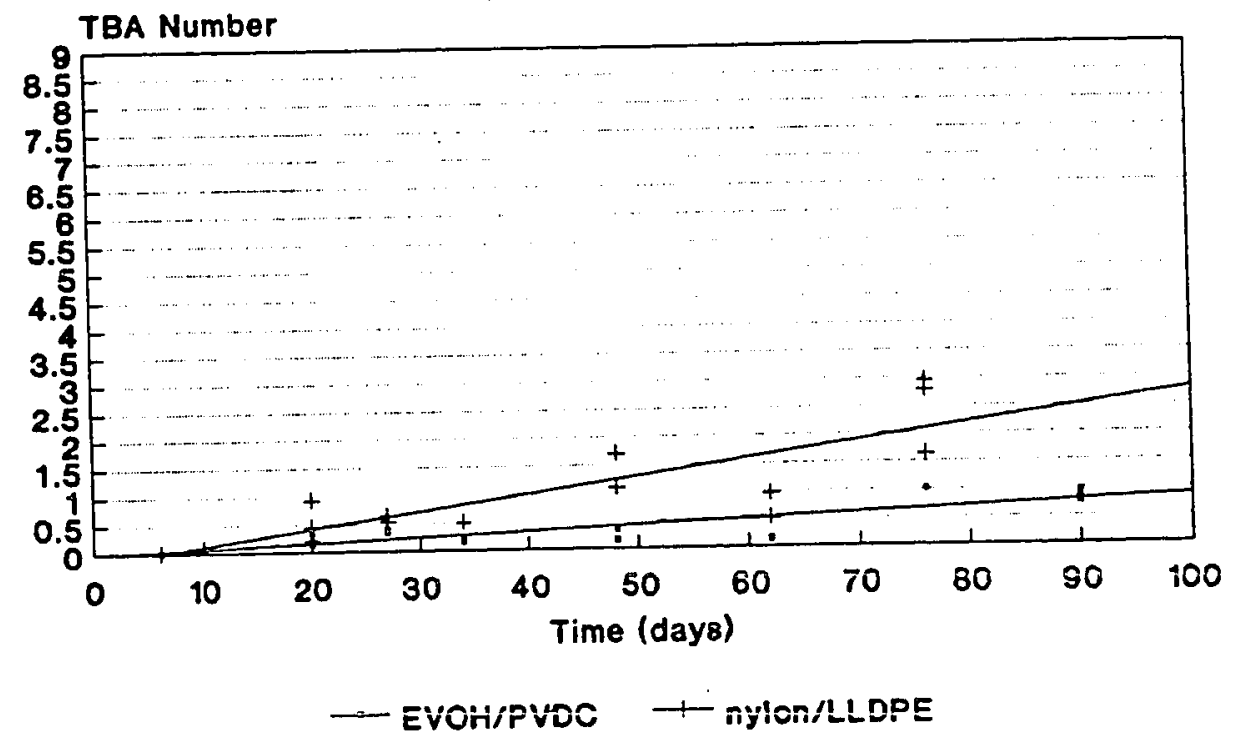

Figure 8. Thiobarbituric Acid values during storage. 
91

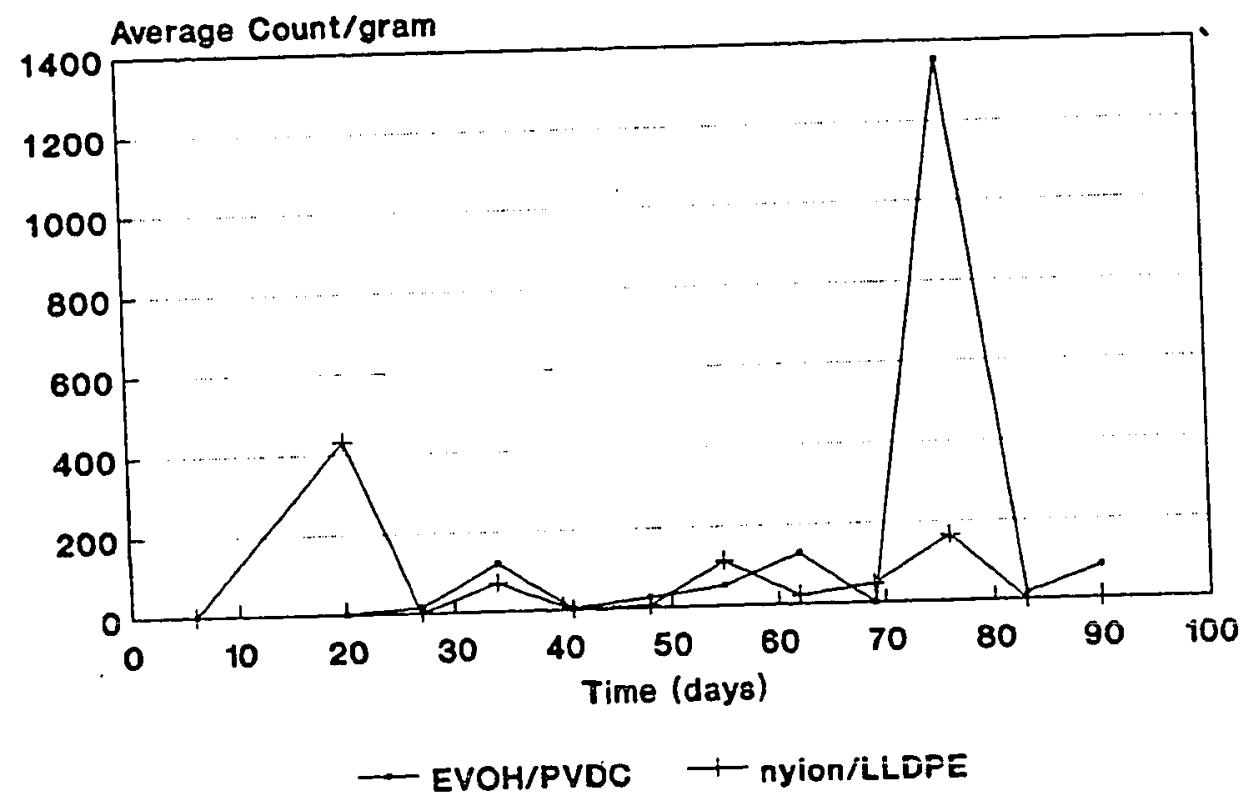

Figure 9. Growth of psychrophiles during storage. 


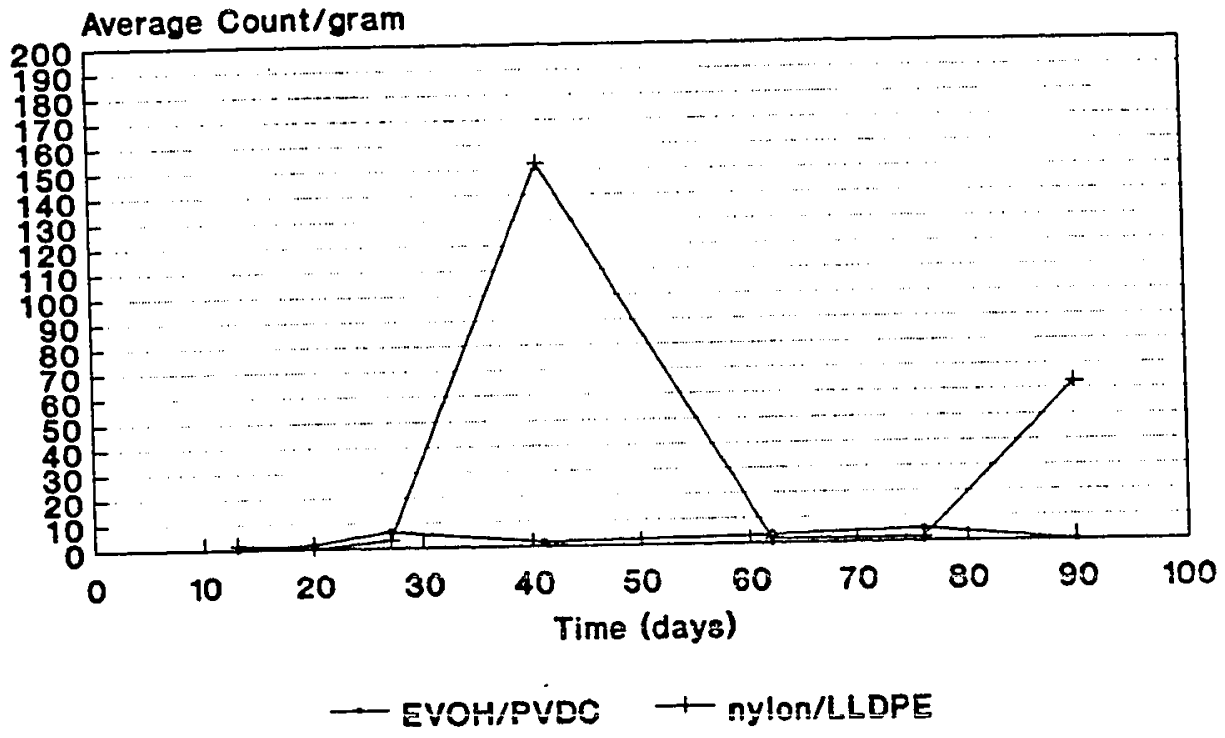

Figure 10. Growth of Lactobacilius during storage. 


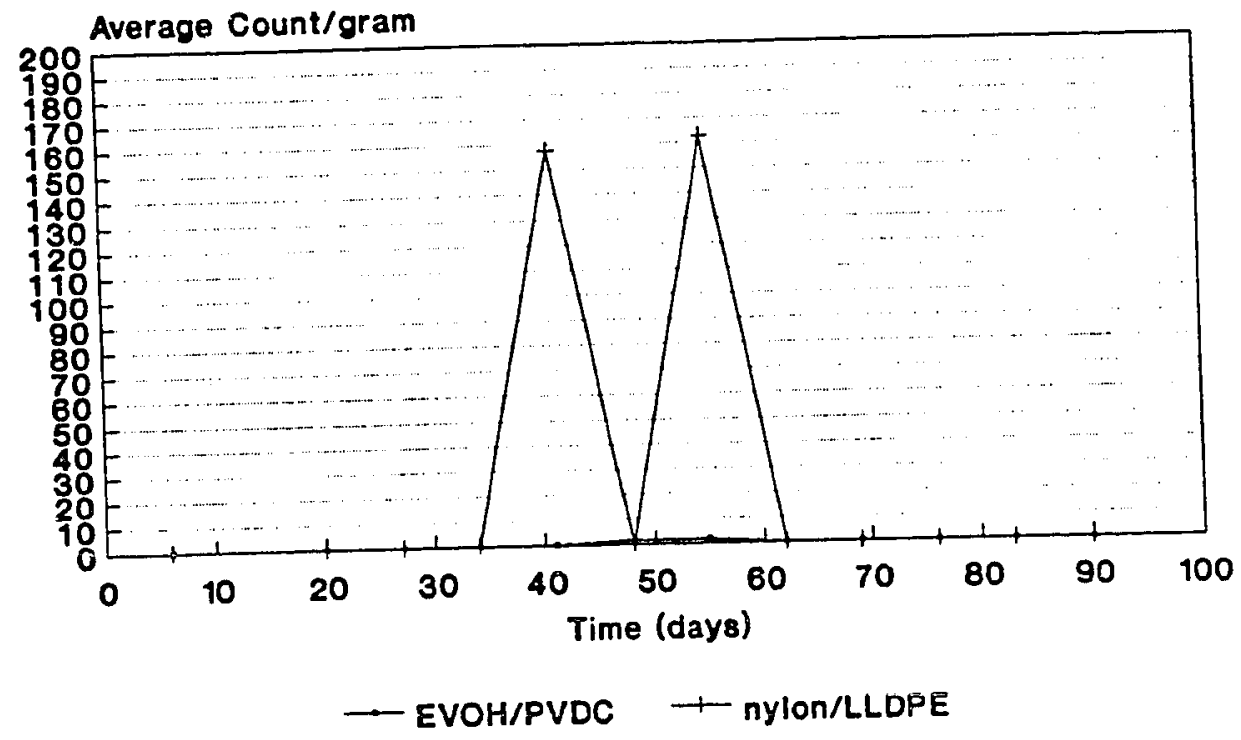

Figure 11. Growth of anaerobes/facultatives during storage. 


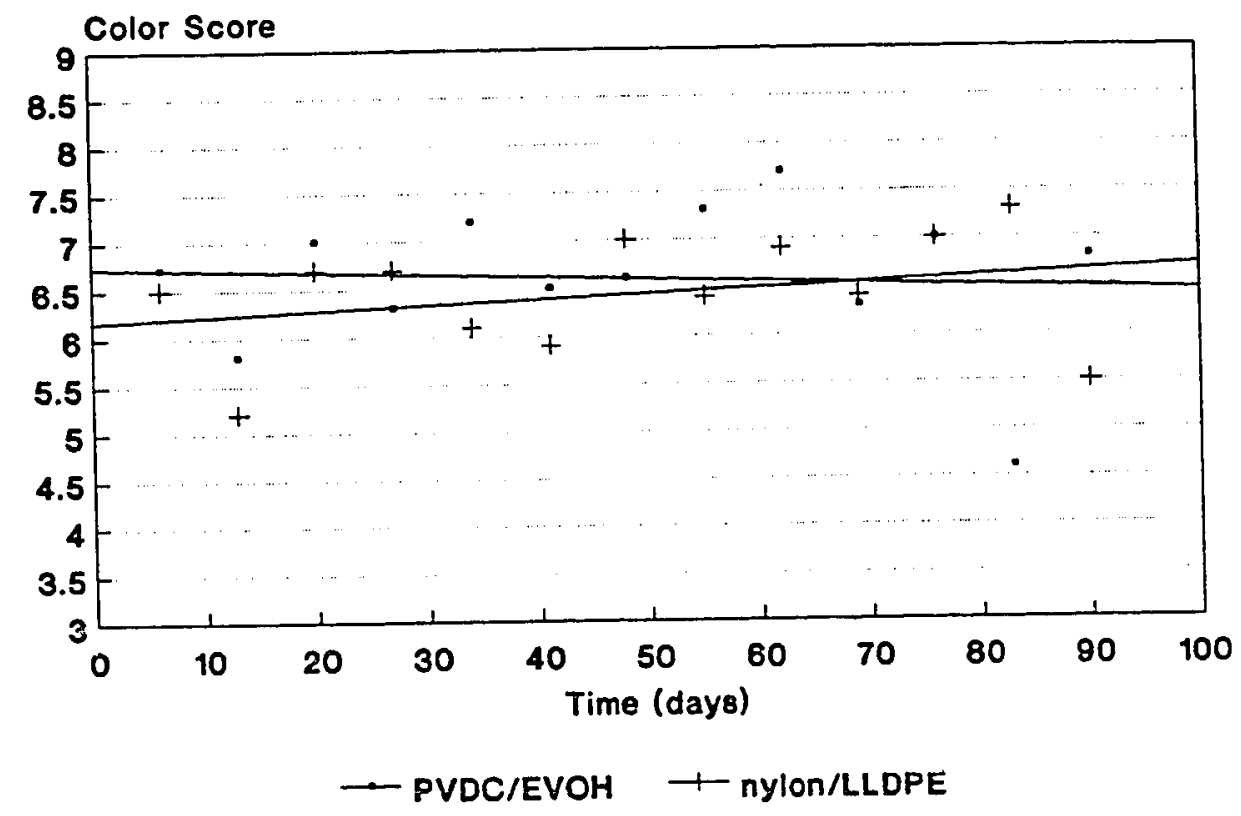

Figure 12. Sensory evaluation color scores over time. 


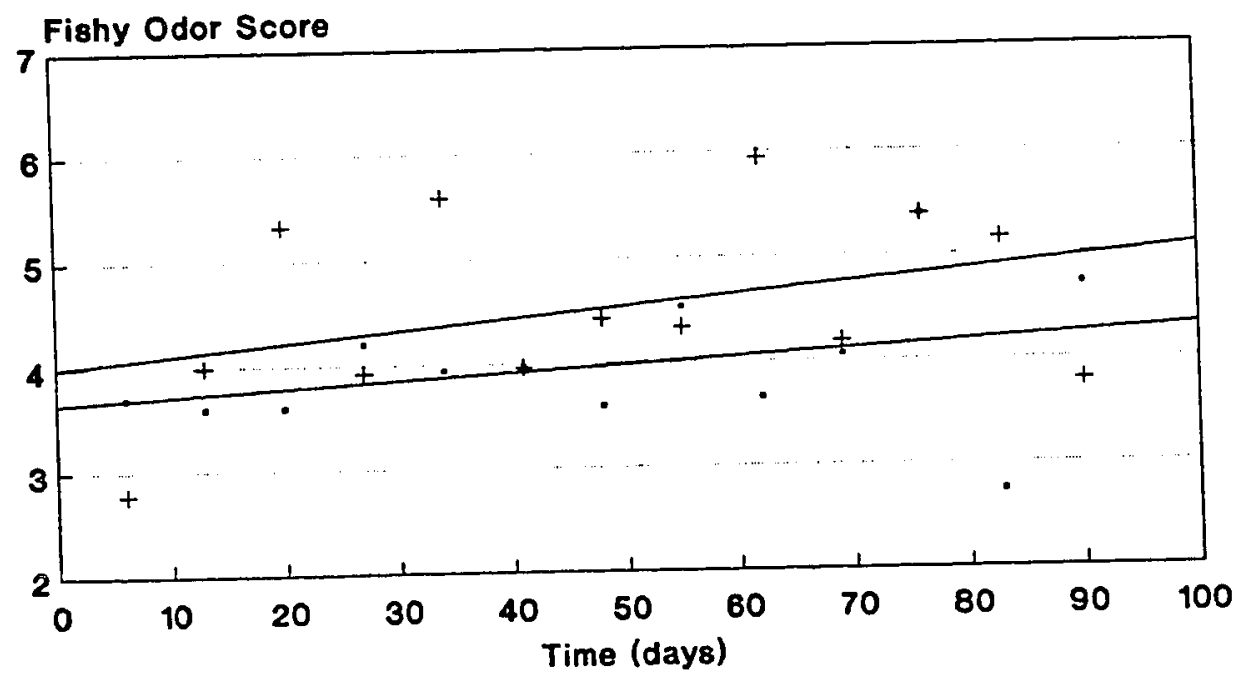

- PVDC/EVOH Tylon/LLDPE

Figure 13. Sensory evaluation scores for fishy aroma over time. 


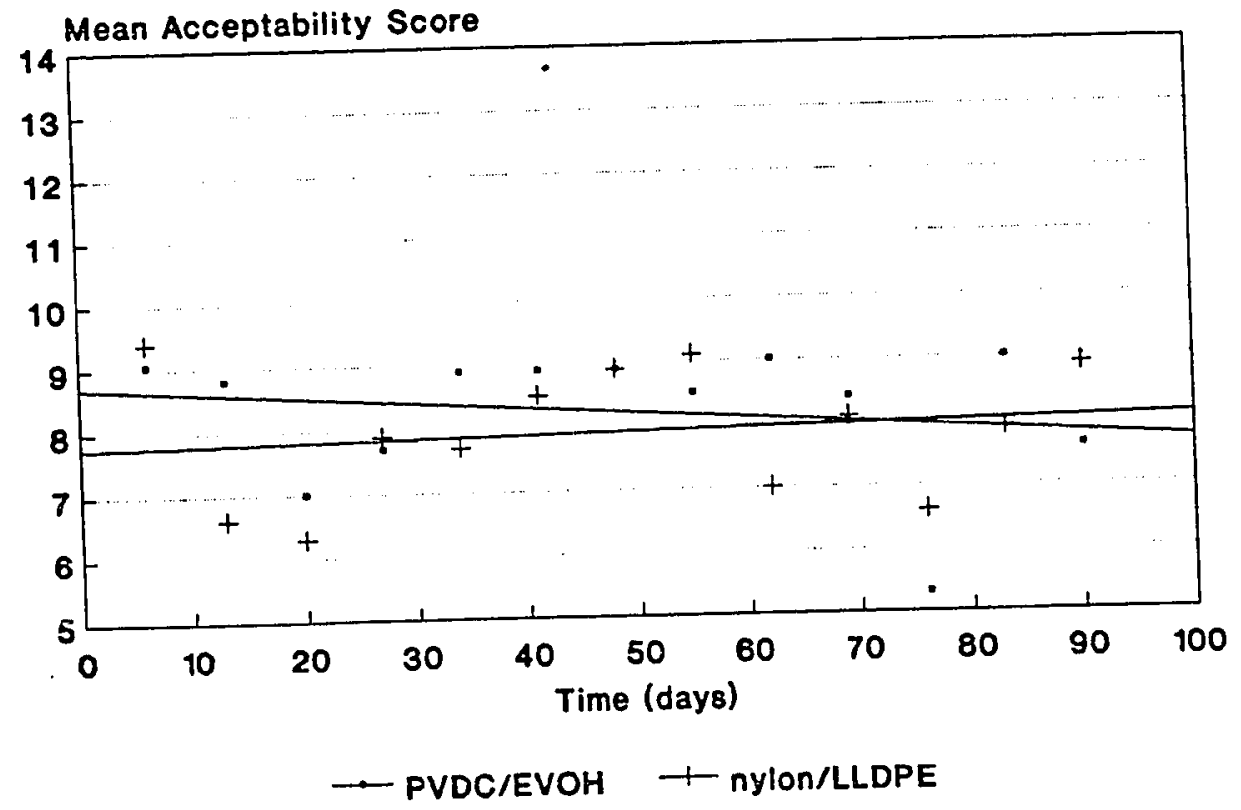

Figure 14. Sensory evaluation scores for overall acceptability over time. 
CHAPTER 3

SUMMARY AND RECOMMENDATIONS

\section{Summary}

This study was initiated to investigate various physical, chemical, and sensory modes of deterioration in sous-vide processed salmon during refrigerated storage (0$\left.4^{\circ} \mathrm{C}\right)$. The samples were also evaluated microbiologically during the study to assure that the changes that were occurring during storage were indeed attributable to physical and/or chemical changes, and not to microbial degradation. The protective effects of two types of packages, PVDC/nylon/EVOH/LLDPE and nylon/LLDPE, were also examined. Of the two physical indices evaluated, textural changes and drip loss, drip volume increased notably during storage. The rate of exudate loss was slightly greater in the nylon/LLDPE packaged fillets. The increase in drip loss indicated a leaching of water from the fish muscle and, presumably, a consequent increase in dryness. Textural changes, as measured by the Instron Universal Testing Machine were highly variable and were determined not to be indicative of the textural quality of the salmon fillets during the study. It was hypothesized that some textural changes were occurring since there were both drip and protein losses from the fish muscle.

The chemical indices examined were lipid oxidation using Thiobarbituric Acid (TBA) assays, color changes using the Hunter Color Difference Meter, and nitrogen composition 
and concentration changes in the drip using the Kjeldahl distillation method. TBA values increased during storage, however, values (except for one) did not exceed the value of four, a level accepted as indicative of oxidative rancidity. Therefore, we concluded that lipid oxidation was not a limiting factor in the shelf-life of sous-vide salmon, regardless of the presence or absence of an EVOH barrier.

Hunter Color Difference Meter results appeared to provide no indication of any color changes occurring in the fillets during storage.

Nitrogen composition changes in the drip were different between the fillets stored in different packages, although the overall total nitrogen concentrations in the total drip volume were relatively the same. In the PVDC/nylon/EVOH/ LLDPE samples, the protein and non-protein fractions of the total nitrogen composition remained relatively proportional to each other during storage. However, in the nylon/LLDPE packaged samples, the non-protein fraction increased at a much greater rate than the protein fraction. It was suggested that there was protein degradation in these fillets which released free amino acids and peptides contributing to the non-protein nitrogen pool. In the EVOHprotected samples, gelling occurred at 55 days of storage, indicating possible breakdown of collagenous proteins. In the nylon/LLDPE samples, gelling occurred at around day 83 . Sensory evaluation data indicated that the nylon/LLDPE samples had significantly higher levels of fishy odor 
throughout the storage period. At day 76, a spoiled salmon fillet packaged in the PVDC/EVOH package was discovered. since the samples used for sensory evaluations were not evaluated physically, chemically, or microbiologically, the exact cause of the spoilage was not identified. However, it was highly likely that the cause was microbiological because of the putridness of the odor. The fact that the samples were not evaluated from a flavor standpoint was a consiäerable limitation to this study. However, due to the lack of specialized facilities for testing for the presence of clostridium botulinum, the safety of the products could not be guaranteed past the 21 day shelf-life currently promoted by the company.

Recommendations

The results of this study will be used in conjunction with microbiological data from other studies on sous-vide salmon to determine shelf-life from both safety and quality standpoints. Safety, however, is always the most important factor with regard to establishing shelf-life of any product. This study showed that although there were physical and chemical changes occurring in the sous-vide salmon fillets, the changes did not become significant factors until much later in the storage period. Therefore, the most limiting factor for shelf-life appears to be microbiological. Due to the unique nature of the sous-vide process, the packaging system it utilizes, and the low storage temperature, physical and chemical mechanisms of 
decay appear to have occurred at slow rates. These products can be microbiologically stable beyond the 21 day shelf-life when stored at or below $3.3^{\circ} \mathrm{C}$. However, special attention must be given to clostridium botulinum because of its ability to survive the pasteurization process and grow under the environmental conditions of the sous-vide package system should temperature abuse occur.

other sous-vide products may need to be evaluated physically and/or chemically to insure that these mechanisms will not affect the quality of the product during storage. 


\section{REFERENCES}

Abrahamsson, K.; Gullmar, B., \& Molin, N. (1966). The effect of temperature on toxin formation and toxin stability of clostridium botulinum type $e$ in different environments. Journal of Food Science, 12, 385-394. Anderson, D. C. (1983). Vacuum packaging of frozen and fresh fisheries products. Paper No. 153, presented at 43 rd Annual Meeting of Inst. of Food Technologists, New Orleans, LA, June 19-22.

Anonymous $^{\mathrm{a}}$. (1988, September). Package, precautions set sous-vide line apart. Food and Drug Packaging, pp. 3, 16. Anonymous $^{b}$. (1989, June). B \& I operators told: Get ready for sous-vide. Foodservice Director, pp. 1. Anonymous ${ }^{c}$. (1989, March). Chilling innovations. Meat Processing.

Anonymous ${ }^{d}$ (1985). Packaging of fish: Available Systems. Revue Technique veterinaire de 1' alimentation, 42, 11-14. (From Food Science and Technology Abstracts, 1985, 13 , Abstract No. 207).

Anonymouse. (1983, March). Atmosphere of Success. Packaging Review, UK, pp. 32. Association of Analytical Chemists. (1984) - Official methods of analysis (14th ed.) Washington, DC. American Public Health Association. (1984). Compendium of methods for the microbiological examination of foods (2nd ed,) Washington, DC.

Baker, D. A. and Genigeorgis, C. (1989). Microbiological 
risk assessment of refrigerated foods: The safety of sous-vide products. Presented at Xth International Symposium of the World Association of Veterinary Food Hygienists, Stockholm, Sweden, July 2-7.

Belitz, H. D. \& Gosch, w. (1987). Food chemistry. New York: Springer-Verlag Berlin.

Bhatty, R. S. \& Finlayson, A. J. (1973). Extraction of nonprotein nitrogen from oilseed meals with different solvents. The Journal of Cereal Chemistry, 50(3), 329336.

Banwart, G. J. (1981). Basic food microbiology (abridged ed.). Westport, Connecticut: AVI Publishing Co., Inc. Barnett, H. J., Conrad, J. W., \& Nelson, R. W. (1987). Use of laminated high and low density polyethylene flexible packaging to store trout (salmo gairdneri) in a modified atmosphere. Journal of Food Protection, 50(8): 645-651. Bradfield, K. (1984, Jan./Feb.) clearly a better pack for the holden du cros. Frozen and Chilled Foods, pp. 52-53. Connell, J. J. (1975) - Control of fish quality. Farnham, Surrey, England: Fishing News Books, Ltd.

Deibel, R. H. \& Lindquist, J. A. (1981). General food microbiology laboratory manual, Minneapolis, Minnesota: Burgess Publishing Co. Densford, L. (1988, April) . Food and Drug Packaging, pp. 4, 40. Ellinger, R. H. (1972): Phosphates as food ingredients. Chicago: CRC Press. 
Garcia, G. W., Genigeorgis, C., \& Lindroth, s. (1987) - Risk of growth and toxin production by clostridium botulinum nonproteolytic types $b, e$, and $f$ in salmon fillets stored under modified atmospheres at low and abused temperatures. The Journal of Food Science, 50(4), 330-336.

Genigeorgis, C. A. (1988). Microbiological risk assessment in foods packaged under modified atmospheres. Presented at the Pack Alimentaire.

Godber, J. S., Wang, J., Cole, M. T., \& Marshall, G. A. (1989). Textural attributes of mechanically and cryogenically frozen whole crayfish (procambarus clarkii). The Journal of Food Science, 54(3), 564-566.

Goldsmith, S. M. (1980). Water holding and structure forming properties of comminuted carp as influenced by the addition of sodium chloride and sodium tripolyphosphate. Unpublished master's thesis, University of Minnesota. Hackney, C. R. \& Dicharry, A. (1988, March). Food Technology, pp. 104-109.

Hebard, C. E., Flick, G. J., \& Martin, R. E. (1982). occurrence and significance of trimethylamine oxide and its derivatives in fish and shellfish. In R. E. Martin, G. J. Flick; c. E. Hebard, \& D. R. Ward (Eds.) Chemistry and biochemistry of marine food products. Westport, Connecticut: AVI Publishing Co. Hintlian, C. B. \& Hotchkiss, J. H. (1986, December) - Food Technology, pp. 70-76.

Hutlin, H. O., McDonald, R. E., \& S. D. Kelleher. (1982). 
Iipid oxidation in fish muscle microsomes. In R. E. Martin, G. J. Flick, C. E. Hebard, \& D. R. Ward (Eds.) . Chemistry and biochemistry of marine food products. Westport, Connecticut: AVI Publishing Co.

Instron corporation. (1972). Texture Evaluation of Cooked Meat. Canton, Massachusettes.

Kramer, L. (1988, January). Is it real or is it sous-vide? Catering Today. pp. 25-27.

Levine, J. B. \& Rossant, J. (1987, July). Sous-vide cooking: haute cuisine in a pouch? Business week, pp. 104.

Licciardello, J. J., Ravesi, E. M., \& Allsup, M. G. (1980). Extending the shelf life of frozen argentine hake. The Journal of Food Science, 45, 1312-1317.

Licciardello, J. J., Ravesi, E. M., \& Allsup, M. G. (1982). stabilization of the flavor of frozen minced whiting: Effect of various antioxidants. Marine Fisheries Review (Vol. 44, No. 8). Gloucester, Maryland.

Liston, J. (1982). Recent advances in the chemistry of iced fish spoilage. In Martin, R. E., Flick, G. J., Hebard, C. E., and Ward, D. R. (Eds.), Chemistry and biochemistry of marine food products, (pp. 27-37). Westport, Connecticut: AVI Publishing co.

Londahl, G. (1981). Refrigerated storage in fisheries (Technical Report No. 214). Rome, Italy: Food and Agriculture organization of the United Nations. Love, M. (1984). Texture and the fragility of fish muscle 
cells. Journal of Texture Studies, 14, 323-352.

Melton, S. L. (1983, July). Methodology for following lipid oxidation in muscle foods. Food Technology, pp. 105-116.

Nakayama, T. \& Yamamoto, M. (1977). Physical, chemical, and sensory evaluations of frozen-stored deboned (minced) fish flesh. The Journal of Food Science, 42 (4), 900-905. Pearson, D. (1976). The chemical analysis of foods (7th ed.). New York: Chemical Publishing Co., Inc.

Post, L. S., Lee, D. A., Solberg, M., Furgang, D., Specchio, J., \& Graham, C. (1985). Development of botulinal toxin and sensory deterioration during storage of vacuum and modified atmosphere packaged fish fillets. The Journal of Food Science, 50, 990-996.

Regenstein, J. M., Schlosser, M. A., Samson, A., \& Fey, M. (1982). Chemical changes of trimethylamine oxide during fresh and frozen storage of fish. In R. E. Martin, G. J. Flick, C. E. Hebard, \& D. R. Ward (Eds.) Chemistry and biochemistry of marine food products. Westport, Connecticut: AVI Publishing Co.

Samson, A., Regenstein, J. M., \& Laird, W. M. (1985) . Measuring textural changes in frozen minced cod flesh. Journal of Food Biochemistry, 9, 147-159.

simpson, K. L. (1982). Carotenoid pigments in seafood. In R. E. Martin, G. J. Flick, C. E. Hebard, \& D. R. Ward (Eds.) Chemistry and biochemistxy of marine food products. Westport, Connecticut: AVI Publishing Co. sinnhuber, R. O., Yu, T. C., \& Yu, T. C. (1958, September). 
Characterization of the red pigment formed in the 2thiobarbituric acid determination of oxidative rancidity. Food Technology, pp. 626-633.

Spinelli, J. \& Dassow, J.A. (1982). Fish proteins: Their modification and potential uses in the food industry. In R. E. Martin, G. J. Flick, C. E. Hebard, \& D. R. Ward (Eds.) Chemistry and biochemistry of marine food products. Westport, Connecticut: AVI Publishing Co.

Stansby, M. E. (1982): Properties of fish oils and their application to handling of fish and to nutritional and industrial use. In R. E. Martin, G. J. Flick, C. E. Hebard, \& D. R. Ward (Eds.) Chemistry and biochemistry of marine food products. Westport, Connecticut: AVI 110 Publishing Co.

stier, R. F., Bell, L., Ito, K. A., Shafer, B. D., Brown, L. A., Seeger, M. L., Allen, B. H., Porcuna, M. N., \& Lerke, P.A. (1981). Effect of modified atmosphere storage on $\mathbf{c}$. botulinum toxigenesis and the spoilage microflora of salmon fillets. The Journal of Fooa Science, 46, 16390 1642 .

Stone, H. \& Sidel, J. L. (1985). Sensory Evaluation Practices. Orlando, Florida: Academic Press, Inc. Swientek, R. J. (1989, June). Sous-vide, refrigerated upscale food in a vacuum pouch. Food processing, pp. 3439.

Tarladgis, B. G., Watts, B. H., Younathan, M. T. \& Dugan, L., Jr. (1960). A distillation method for the 
quantitative determination of malonaldehyde in rancid foods. Journal of the American Chemical Society, 37, 4448 .

Unda, J. R., Molins, R. A., and Walker, H. W. (1990). Microbiological and some physical and chemical changes in vacuum-packaged beef steaks treated with combinations of potassium sorbate, phosphate, sodium chloride, and sodium acetate. The Journal of Food Science, $\underline{55}(2), 323-326$. Zipser, M. W. and Watts, B. M. (1961). oxidative rancidity in cooked mullet. Food Technology, 6 , 318-321. 
APPENDICES 
Appendix A

Sensory Evaluation Scoresheet

Quantitative Descriptive Analysis Scoresheet

for Evaluation of Refrigerated Sous-vide Brocessed Solmon

Judge Number

Date

Code

Please place a single single vertical mark across the horizontal line at the point which best describes your perception of the intensity of that attribute in the sample.

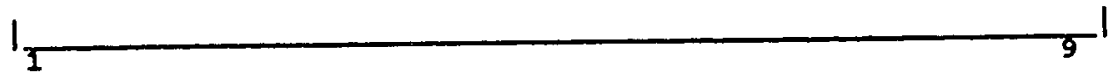

\section{Appearance}

surface color

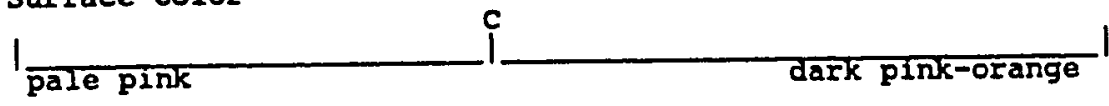

Flakiness

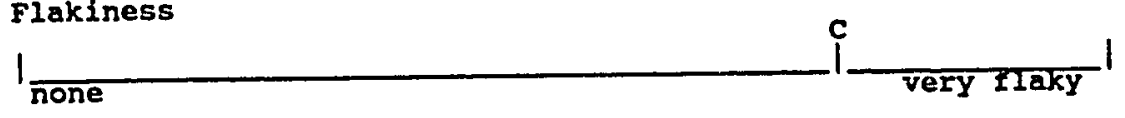

Crumbliness

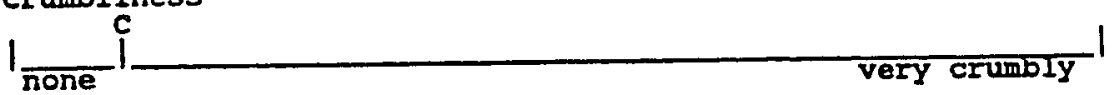

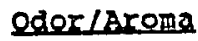

Elshiness

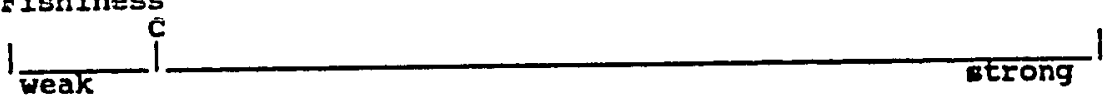

anmonia

I weak

other (describe)

overald Acceptablilty

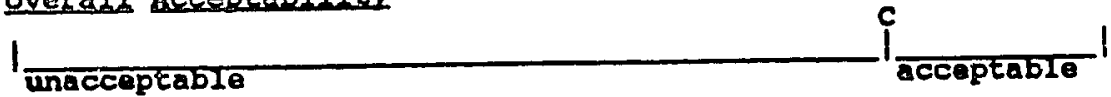


Appendix B

Human Consent Form

\title{
AGREEMENT TO PARTICIPATE IN RESEARCH
}

AT SAN JOSE STATE UNIVERSITY

\author{
RESPONSIBLE INVESTIGATOR: BETH RACHEL GITTLESON \\ GRADUATE STUDENT, \\ FOOD SCIENCE
}

\begin{abstract}
TITLE OF PROTOCOL: DETERMINATION OF THE PHYSICO-CHEMICAL MODES OF DETERIORATION AND SHELF-LIFE ENDPOINTS OF REFRIGEERATED SOUS-VIDE PROCESSED SALMON
\end{abstract}

I have been asked to participate in an experimental research study that is investigating the physical and chemical modes of deterioration and shelf-life endpoints for sous-vide processed salmon.

The results of this study should further our understanding regarding the mechanisms of decay in sous-vide processed salmon as well as furnish the shelf-life endpoints based upon these modes of degredation.

In addition, the effects of 1) freezing and 2) the inclusion of an EVOH barrier in the package will be evaluated for its effect on shelf-life stability of the salmon.

I understand that:

1) I will be asked to evaIuate rour sous-vide salmon samples (compared against a control) on a weekly basis for 12 weeks using quantitative descriptive analysis techniques of sensory analysis. The refrigerated samples will be evaluated for visual and aroma defects only. In addition, I will be asked to evaluated four samples on a monthly basis for six months. The monthly evaluations will consist of visual, aroma, and flavor analyses.

2) I will be involved in two training sessions (each one hour in length) that will show me how to use descriptive analysis in the sensory evaluation of this product. The training sessions will be held one week prior to the onset of the actual study with the dates to be determine with the approval of all the panelists.

3) the weekly and monthly evaluations will be conducted on the Tuesday of each week at 5:30 p.m. in room 115 in the 


\section{Appendix B (continued)}

Central Classroom Building on the San Jose state University campus.

4) the possible risks of the study include exposure to packaged salmon samples that may contain significant numbers of microorganisms toward the end of the study. There is no risk involved in tasting the frozen samples as there is no microbial growth during frozen storage. I will not be tasting the refrigerated samples, therefore there is no risk in evaluating those samples. In addition, time I may lose from work or other daily activities in order to participate in the training sessions and weekly evaluations could be viewed as risks or disadvantages.

5) the possible benefit of this study to me is involvement in sensory analysis that will lead to a greater understanding of my own sensory perception. An additional benefit is exposure to a new and exciting product that has newly entered the food industry.

6) I will be paid $\$ 25.00$ for participating in this study. I will receive this compensation on the day of the final sensory evaluation.

7) the results of this study may be published or presented at a professional meeting, but any information from this study that can be identified with me will remain confidential and will be disclosed only with my permission or as required by law.

8) any questions about my participation in this study will be answered by Beth Gittleson at 408-926-3913. Complaints about the procedures may be presented to Dr. Miriam Saitmarch (Food Science instructor, 408-9243107 ) or $\mathrm{Dr}$. Lucy McProud (chairperson for the Department of Nutrition and Food Science, 408-924-3100). For questions or complaints about research subject's rights, or in the even of research-related injury, contact Serena stanford, Ph.D. (Associate Academic Vice President for Graduate studies) at 408-277-2943.

9) my consent is given voluntarily without being coerced; I may refuse to participate in this study or in any part of this study, and I may withdraw at any time, without prejudice to my relations with San Jose State University. 
Appendix B (continued)

I have received a copy of this consent form for my file. I HAVE MADE A DECISION WHETHER OR NOT TO PARTICIPATE. HY
SIGINATURE INDICATES THAT I HAVE READ THE INFORMATION PROVIDED ABOVE AND THAT I HAVE DECIDED TO PARTICIPATE.

$\overline{\text { Date }}$
Subject's Signature

Investigator's signature 
Appendix C

Instron Data for Salmon stored in the PVDC/EVOH Package

\begin{tabular}{|c|c|c|c|}
\hline Time & (days) & Sample Number & $\begin{array}{l}\text { Force } \\
(\mathrm{gm} / \mathrm{sq} \mathrm{cm})\end{array}$ \\
\hline & 6 & $\begin{array}{l}80 \\
82 \\
73\end{array}$ & $\begin{array}{r}92.00 \\
123.14 \\
249.12\end{array}$ \\
\hline & 13 & $\begin{array}{r}129 \\
124 \\
46\end{array}$ & $\begin{array}{l}135.88 \\
172.68 \\
209.48\end{array}$ \\
\hline & 20 & $\begin{array}{l}42 \\
37 \\
43\end{array}$ & $\begin{array}{c}113.23 \\
101.91 \\
-\end{array}$ \\
\hline & 27 & $\begin{array}{l}125 \\
127 \\
114\end{array}$ & $\begin{array}{c}141.54 \\
101.91 \\
-\end{array}$ \\
\hline & 34 & $\begin{array}{r}45 \\
120 \\
117\end{array}$ & $\begin{array}{c}113.23 \\
101.91\end{array}$ \\
\hline & 41 & $\begin{array}{r}71 \\
116 \\
84\end{array}$ & $\begin{array}{c}-\overline{--} \\
175.51 \\
198.16\end{array}$ \\
\hline & 48 & $\begin{array}{l}3 \\
4 \\
5\end{array}$ & $\overline{---}$ \\
\hline & 55 & $\begin{array}{l}74 \\
76 \\
93\end{array}$ & $\begin{array}{l}169.85 \\
198.16 \\
147.20\end{array}$ \\
\hline & 62 & $\begin{array}{l}81 \\
85 \\
86\end{array}$ & $\begin{array}{l}198.16 \\
254.78 \\
141.54\end{array}$ \\
\hline
\end{tabular}


Appendix C (continued)

\begin{tabular}{ccc}
\hline Time (days) & Sample Number & $\begin{array}{c}\text { Force } \\
\text { (gm/sq cm) }\end{array}$ \\
\hline 69 & 113 & 159.94 \\
& 79 & 141.54 \\
76 & 88 & 131.63 \\
& 68 & 206.65 \\
& 66 & 75.02 \\
& 91 & 169.85 \\
& 78 & 99.08 \\
& 90 & 212.31 \\
90 & 103 & 99.08 \\
& 94 & 148.62 \\
& 109 & 226.47
\end{tabular}


Appendix D

Instron Data for salmon stored
in the nylon/LLDPE

\begin{tabular}{|c|c|c|c|}
\hline Time & (days) & Sample Number & $\begin{array}{l}\text { Force } \\
(\mathrm{gm} / \mathrm{sq} \mathrm{cm})\end{array}$ \\
\hline & 6 & $\begin{array}{l}9 \\
1 \\
2\end{array}$ & $\begin{array}{l}176.93 \\
198.16 \\
186.84\end{array}$ \\
\hline & 13 & $\begin{array}{l}57 \\
60 \\
63\end{array}$ & $\begin{array}{l}135.88 \\
147.20 \\
135.88\end{array}$ \\
\hline & 20 & $\begin{array}{l}36 \\
38 \\
44\end{array}$ & $\begin{array}{l}186.85 \\
175.51 \\
135.88\end{array}$ \\
\hline & 27 & $\begin{array}{l}51 \\
54 \\
56\end{array}$ & $\begin{array}{r}144.37 \\
79.26 \\
53.79\end{array}$ \\
\hline & 34 & $\begin{array}{l}53 \\
47 \\
48\end{array}$ & $\begin{array}{l}198.16 \\
175.51 \\
147.20\end{array}$ \\
\hline & 41 & $\begin{array}{r}52 \\
55 \\
8\end{array}$ & $\begin{array}{l}280.25 \\
158.53 \\
175.51\end{array}$ \\
\hline & 48 & $\begin{array}{r}6 \\
7 \\
10\end{array}$ & $\begin{array}{l}-- \\
-- \\
--\end{array}$ \\
\hline & 55 & $\begin{array}{l}13 \\
17 \\
20\end{array}$ & $\begin{array}{l}226.47 \\
130.22 \\
118.90\end{array}$ \\
\hline & 62 & $\begin{array}{l}22 \\
19 \\
24\end{array}$ & $\begin{array}{c}184.00 \\
212.31 \\
-\end{array}$ \\
\hline
\end{tabular}


Appendix D (continued)

\begin{tabular}{ccc}
\hline Time (days) & Sample Number & $\begin{array}{c}\text { Force } \\
(\mathrm{gm} / \mathrm{sq} \mathrm{cm})\end{array}$ \\
\hline \multirow{2}{*}{69} & 35 & 158.53 \\
& 26 & 169.85 \\
& 31 & 128.80 \\
76 & 25 & 94.83 \\
& 33 & 133.05 \\
& 28 & 141.54 \\
& 211 & 155.70 \\
& 212 & 176.93 \\
& 213 & 176.93 \\
& 214 & 148.62 \\
& 209 & 141.54 \\
& 210 & -9
\end{tabular}


Appendix E

Malonaldehyde Concentration in Salmon Samples stored in the PVDC/EVOH Package

\begin{tabular}{|c|c|c|c|}
\hline Time & (days) & Sample Number & $\begin{array}{l}\text { Malonaldehyde Concentration } \\
\text { (moles } \times 10^{-8} / 5 \mathrm{ml} \text { ) }\end{array}$ \\
\hline & 6 & $\begin{array}{l}80 \\
82 \\
73\end{array}$ & $\begin{array}{l}0.0000 \\
0.0000 \\
0.0000\end{array}$ \\
\hline & 20 & $\begin{array}{l}42 \\
37 \\
43\end{array}$ & $\begin{array}{l}0.1000 \\
0.0500 \\
0.1500\end{array}$ \\
\hline & 27 & $\begin{array}{l}125 \\
127 \\
114\end{array}$ & $\begin{array}{l}0.2884 \\
0.1807 \\
0.1537\end{array}$ \\
\hline & 34 & $\begin{array}{r}117 \\
120 \\
45\end{array}$ & $\begin{array}{l}0.1180 \\
0.0139 \\
0.0064\end{array}$ \\
\hline & 48 & $\begin{array}{l}3 \\
4 \\
5\end{array}$ & $\begin{array}{l}0.1477 \\
0.0777 \\
0.0593\end{array}$ \\
\hline & 62 & $\begin{array}{l}85 \\
81 \\
86\end{array}$ & $\begin{array}{l}0.0745 \\
0.0570 \\
-----\end{array}$ \\
\hline & 76 & $\begin{array}{l}88 \\
66 \\
68\end{array}$ & $\begin{array}{l}3.8600 \\
0.4900 \\
0.5700\end{array}$ \\
\hline & 90 & $\begin{array}{r}94 \\
103 \\
109\end{array}$ & $\begin{array}{l}0.3386 \\
0.4347 \\
0.3902\end{array}$ \\
\hline
\end{tabular}


Appendix F

Malonaldehyde Concentration in Salmon Samples stored in the NYlon/LLDPE Package

\begin{tabular}{|c|c|c|c|}
\hline Time & (days) & Sample Number & $\begin{array}{l}\text { Malonaldehyde concentration } \\
\left.\text { (moles } \times 10^{-8} / 5 \mathrm{ml}\right)\end{array}$ \\
\hline & 6 & $\begin{array}{l}9 \\
2 \\
1\end{array}$ & $\begin{array}{l}0.0000 \\
0.0000 \\
0.0000\end{array}$ \\
\hline & 20 & $\begin{array}{l}36 \\
38 \\
44\end{array}$ & $\begin{array}{l}0.1000 \\
0.2000 \\
0.4250\end{array}$ \\
\hline & 27 & $\begin{array}{l}51 \\
54 \\
56\end{array}$ & $\frac{0.2974}{0.2534}$ \\
\hline & 34 & $\begin{array}{l}53 \\
47 \\
48\end{array}$ & 0.2218 \\
\hline & 48 & $\begin{array}{r}6 \\
7 \\
10\end{array}$ & $\begin{array}{l}0.7935 \\
0.5135 \\
0.7882\end{array}$ \\
\hline & 62 & $\begin{array}{l}19 \\
22 \\
24\end{array}$ & $\begin{array}{l}0.4479 \\
0.2384 \\
-----\end{array}$ \\
\hline & 76 & $\begin{array}{l}25 \\
28 \\
33\end{array}$ & $\begin{array}{l}0.7800 \\
1.4000 \\
1.3200\end{array}$ \\
\hline & 90 & $\begin{array}{l}209 \\
214 \\
210\end{array}$ & $\begin{array}{l}0.2508 \\
0.2726 \\
-\end{array}$ \\
\hline
\end{tabular}


Appendix G

Data for Non-Protein Nitrogen in the Drip in the PVDC/EVOH Package

\begin{tabular}{|c|c|c|c|}
\hline Time & (days) & $\begin{array}{c}\text { Sample Number } \\
:\end{array}$ & $\begin{array}{c}\text { Non-Protein Nitrogen } \\
(\mathrm{mg} / \mathrm{ml})\end{array}$ \\
\hline & 6 & $\begin{array}{l}80 \\
82 \\
73\end{array}$ & $\begin{array}{l}---- \\
----- \\
----\end{array}$ \\
\hline & 13 & $\begin{array}{r}129 \\
124 \\
46\end{array}$ & $\begin{array}{l}4.122 \\
----\end{array}$ \\
\hline & 20 & $\begin{array}{l}42 \\
37 \\
43\end{array}$ & $\begin{array}{l}3.931 \\
3.385 \\
4.321\end{array}$ \\
\hline & 27 & $\begin{array}{l}125 \\
127 \\
114\end{array}$ & $\begin{array}{l}-\overline{-}-\overline{-} \\
4.670 \\
3.613\end{array}$ \\
\hline & 34 & $\begin{array}{r}45 \\
120 \\
117\end{array}$ & $\begin{array}{l}5.285 \\
-\cdots--\end{array}$ \\
\hline & 41 & $\begin{array}{r}71 \\
116 \\
84\end{array}$ & $\begin{array}{l}3.861 \\
5.203 \\
2.322\end{array}$ \\
\hline & 48 & $\begin{array}{l}3 \\
5 \\
4\end{array}$ & $\begin{array}{l}5.008 \\
4.744 \\
-\end{array}$ \\
\hline & 55 & $\begin{array}{l}74 \\
76 \\
93\end{array}$ & $\ddot{--n}$ \\
\hline
\end{tabular}

*Data omitted due to psychrophilic growth 
Appendix G (continued)

\begin{tabular}{|c|c|c|c|}
\hline Time & (days) & Sample Number & $\begin{array}{l}\text { Non-Protein Nitrogen } \\
(\mathrm{mg} / \mathrm{ml})\end{array}$ \\
\hline & 62 & $\begin{array}{l}81 \\
85 \\
86\end{array}$ & $\begin{array}{l}3.693 \\
-----\end{array}$ \\
\hline & 69 & $\begin{array}{l}113 \\
95 \\
79\end{array}$ & $\begin{array}{l}4.072 \\
3.205 \\
5.441\end{array}$ \\
\hline & 76 & $\begin{array}{l}88 \\
66 \\
68\end{array}$ & $\begin{array}{l}5.795 \\
-\infty--\end{array}$ \\
\hline & 83 & $\begin{array}{l}91 \\
78 \\
90\end{array}$ & $\begin{array}{l}5.408 \\
4.361 \\
4.083\end{array}$ \\
\hline & 90 & $\begin{array}{r}103 \\
94 \\
109\end{array}$ & $\begin{array}{l}4.653 \\
7.062 \\
-----*\end{array}$ \\
\hline
\end{tabular}

* Data omitted due to psychrophilic/Lactobacillus growth 


\section{Appendix $\mathrm{H}$}

Data for Non-Protein Nitrogen in Salmon Exudate in the Nylon/LLDPE Package

\begin{tabular}{|c|c|c|c|}
\hline Time & (days) & Sample Number & $\begin{array}{l}\text { Non-Protein Nitrogen } \\
\text { (mg/ml) }\end{array}$ \\
\hline & 6 & $\begin{array}{l}9 \\
2 \\
1\end{array}$ & $\begin{array}{l}--a-\infty \\
----- \\
-----\end{array}$ \\
\hline & 13 & $\begin{array}{l}57 \\
63 \\
60\end{array}$ & $\begin{array}{l}3.207 \\
3.573 \\
-----\end{array}$ \\
\hline & 20 & $\begin{array}{l}36 \\
38 \\
44\end{array}$ & $\begin{array}{l}4.852 \\
4.004 \\
3.711\end{array}$ \\
\hline & 27 & $\begin{array}{l}51 \\
54 \\
56\end{array}$ & $\frac{3.817}{3.042}$ \\
\hline & 34 & $\begin{array}{l}53 \\
48 \\
47\end{array}$ & $\ddot{--\infty}$ \\
\hline & 41 & $\begin{array}{r}52 \\
55 \\
8\end{array}$ & $\begin{array}{l}4.496 \\
4.723 \\
4.534\end{array}$ \\
\hline & 48 & $\begin{array}{r}6 \\
7 \\
10\end{array}$ & $\begin{array}{l}4.254 \\
4.587 \\
4.134\end{array}$ \\
\hline & 55 & $\begin{array}{l}13 \\
17 \\
20\end{array}$ & 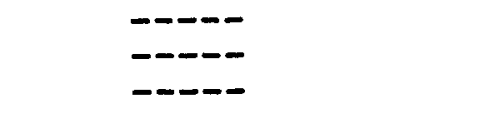 \\
\hline
\end{tabular}

*Data omitted due to Lactobacillus growth 
Appendix H (continued)

\begin{tabular}{|c|c|c|c|}
\hline Time & (days) & Sample Number & $\begin{array}{c}\text { Non-Protein Nitrogen } \\
(\mathrm{mg} / \mathrm{ml})\end{array}$ \\
\hline & 62 & $\begin{array}{l}22 \\
19 \\
24\end{array}$ & $\begin{array}{l}4.937 \\
----\end{array}$ \\
\hline & 69 & $\begin{array}{l}35 \\
31 \\
26\end{array}$ & $\begin{array}{l}4.762 \\
----\infty\end{array}$ \\
\hline & 76 & $\begin{array}{l}25 \\
33 \\
28\end{array}$ & $\begin{array}{l}5.794 \\
5.912 \\
-\end{array}$ \\
\hline & 83 & $\begin{array}{l}212 \\
213 \\
211\end{array}$ & $\ddot{-n-\infty}$ \\
\hline & 90 & $\begin{array}{l}214 \\
209 \\
210\end{array}$ & $\begin{array}{l}-----\star \\
-----\star \\
----\end{array}$ \\
\hline
\end{tabular}

*Data omitted due to Lactobacillus growth 
Appendix I

Data for Total Nitrogen in the Drip in the PVDC/EVOH Package

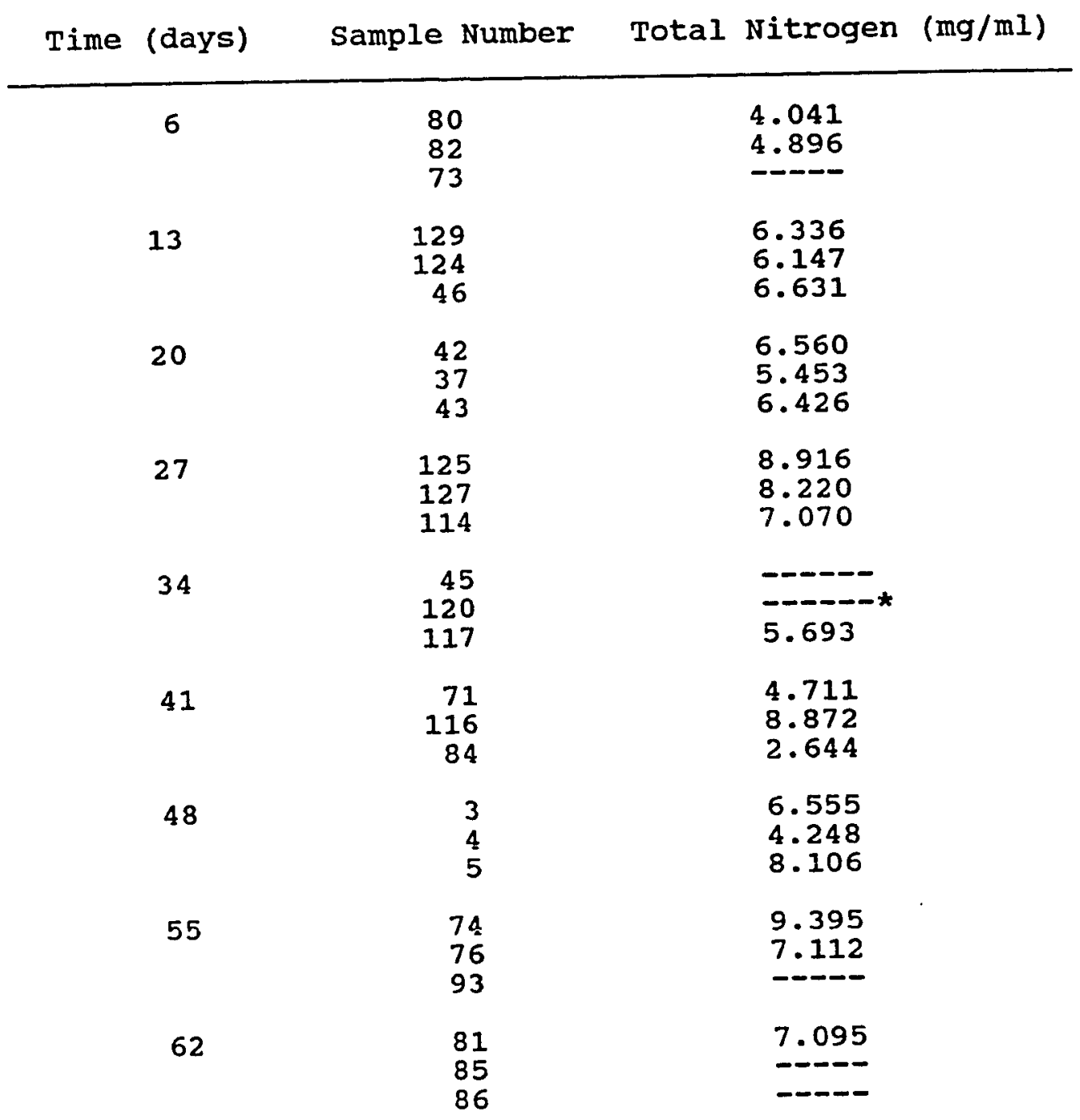

*Data aropped due to high psychrophilic count 
Appendix I (continued)

\begin{tabular}{ccc} 
Time (days) & Sample Number & Total Nitrogen (mg/ml) \\
\hline \multirow{2}{*}{69} & 113 & 8.141 \\
& 95 & 6.463 \\
76 & 88 & 8.324 \\
& 68 & 9.064 \\
& 66 & 8.729 \\
83 & 91 & $-9 .-*$ \\
& 78 & 9.109 \\
& 90 & 7.232 \\
90 & 103 & 6.780 \\
94 & 109 & 9.416 \\
& 90.972
\end{tabular}

*Data dropped due to psychrophilic/Lactobacillus counts 


\section{Appendix $J$}

Data for Total Nitrogen in the Drip
in the NYlon/LLDPE Package

\begin{tabular}{|c|c|c|c|c|}
\hline Time & (days) & Sample Number & Total Nitrogen & $(\mathrm{mg} / \mathrm{ml})$ \\
\hline & 6 & $\begin{array}{l}9 \\
1 \\
2\end{array}$ & $\begin{array}{l}6.006 \\
6.547 \\
-\end{array}$ & \\
\hline & 13 & $\begin{array}{l}57 \\
60 \\
63\end{array}$ & $\begin{array}{l}6.021 \\
6.954 \\
5.747\end{array}$ & \\
\hline & 20 & $\begin{array}{l}36 \\
38 \\
44\end{array}$ & $\begin{array}{l}7.683 \\
6.450 \\
5.751\end{array}$ & \\
\hline & 27 & $\begin{array}{l}51 \\
54 \\
56\end{array}$ & $\frac{5.765}{3.713}$ & \\
\hline & 34 & $\begin{array}{l}53 \\
47 \\
48\end{array}$ & $\begin{array}{l}6.859 \\
9.172\end{array}$ & \\
\hline & 41 & $\begin{array}{r}52 \\
55 \\
8\end{array}$ & $\begin{array}{l}5.759 \\
6.134 \\
6.111\end{array}$ & \\
\hline & 48 & $\begin{array}{r}6 \\
7 \\
10\end{array}$ & $\begin{array}{l}5.687 \\
6.892 \\
5.612\end{array}$ & \\
\hline & 55 & $\begin{array}{l}13 \\
17 \\
20\end{array}$ & $\begin{array}{l}7.873 \\
8.369 \\
7.508\end{array}$ & \\
\hline & 62 & $\begin{array}{l}22 \\
19 \\
24\end{array}$ & $\begin{array}{l}7.278 \\
8.525 \\
-\end{array}$ & \\
\hline
\end{tabular}

*Data omitted due to Lactobacillus growth 
Appendix J (continued)

\begin{tabular}{|c|c|c|c|c|}
\hline Time & (days) & Sample Number & Total Nitrogen & $(\mathrm{mg} / \mathrm{ml})$ \\
\hline & 69 & $\begin{array}{l}35 \\
26 \\
31\end{array}$ & $\begin{array}{l}7.324 \\
--\infty-\end{array}$ & \\
\hline & 76 & $\begin{array}{l}25 \\
33 \\
28\end{array}$ & $\begin{array}{l}8.300 \\
8.508 \\
-\end{array}$ & \\
\hline & 83 & $\begin{array}{l}211 \\
212 \\
213\end{array}$ & $\begin{array}{l}4.928 \\
-\end{array}$ & \\
\hline & 90 & $\begin{array}{l}214 \\
209 \\
210\end{array}$ & $\begin{array}{l}-----* \\
-----* \\
----\end{array}$ & \\
\hline
\end{tabular}

*Data omitted due to psychrophilic/Lactobacillus counts 
Appendix $\mathrm{K}$

Data for Protein Nitrogen in the Exudate in the PVDC/EVOH Package

\section{Time (days) Sample Number Protein Nitrogen}

\begin{tabular}{|c|c|c|}
\hline 6 & $\begin{array}{l}80 \\
82 \\
73\end{array}$ & - \\
\hline 13 & $\begin{array}{r}129 \\
124 \\
46\end{array}$ & $\begin{array}{l}2.214 \\
- \\
----\end{array}$ \\
\hline 20 & $\begin{array}{l}42 \\
37 \\
43\end{array}$ & $\begin{array}{l}2.629 \\
2.068 \\
2.105\end{array}$ \\
\hline 27 & $\begin{array}{l}125 \\
127 \\
114\end{array}$ & $\begin{array}{l}--550 \\
3.550 \\
3.457\end{array}$ \\
\hline 34 & $\begin{array}{r}45 \\
120 \\
117\end{array}$ & $\begin{array}{l}---- \\
---- \\
---\infty\end{array}$ \\
\hline 41 & $\begin{array}{r}71 \\
116 \\
84\end{array}$ & $\begin{array}{l}0.850 \\
3.669 \\
0.322\end{array}$ \\
\hline 48 & $\begin{array}{l}3 \\
5 \\
4\end{array}$ & $\begin{array}{l}1.547 \\
3.362 \\
-\end{array}$ \\
\hline 55 & $\begin{array}{l}74 \\
76 \\
93\end{array}$ & - \\
\hline 62 & $\begin{array}{l}81 \\
85 \\
86\end{array}$ & 3.402 \\
\hline
\end{tabular}


Appendix K (continued)

\begin{tabular}{|c|c|c|c|}
\hline Time & (days) & Sample Number & $\begin{array}{c}\text { Protein Nitrogen } \\
(\mathrm{mg} / \mathrm{ml})\end{array}$ \\
\hline & 69 & $\begin{array}{r}113 \\
95 \\
79\end{array}$ & $\begin{array}{l}4.069 \\
3.258 \\
2.883\end{array}$ \\
\hline & 76 & $\begin{array}{l}88 \\
66 \\
68\end{array}$ & $\begin{array}{l}3.269 \\
----\end{array}$ \\
\hline & 83 & $\begin{array}{l}91 \\
78 \\
90\end{array}$ & $\begin{array}{l}3.701 \\
2.871 \\
2.697\end{array}$ \\
\hline & 90 & $\begin{array}{r}103 \\
94 \\
109\end{array}$ & $\begin{array}{l}2.763 \\
2.910 \\
----\star\end{array}$ \\
\hline
\end{tabular}

*Data omitted due to psychrophilic/Lactobacillus growth 
Appendix L

Data for Protein Nitrogen in Salmon Exudate in the Nylon/LLDPE Package

\begin{tabular}{|c|c|c|c|}
\hline Time & (days) & Sample Number & Protein Nitrogen ( $\mathrm{mg} / \mathrm{ml})$ \\
\hline & 6 & $\begin{array}{l}9 \\
2 \\
1\end{array}$ & $\begin{array}{l}---\infty \\
--\infty \\
---\infty\end{array}$ \\
\hline & 13 & $\begin{array}{l}57 \\
63 \\
60\end{array}$ & $\begin{array}{l}2.814 \\
2.174 \\
-\end{array}$ \\
\hline & 20 & $\begin{array}{l}36 \\
38 \\
44\end{array}$ & $\begin{array}{l}2.831 \\
2.446 \\
2.040\end{array}$ \\
\hline & 27 & $\begin{array}{l}51 \\
54 \\
56\end{array}$ & $\frac{1.948}{0.671}$ \\
\hline & 34 & $\begin{array}{l}53 \\
48 \\
47\end{array}$ & $\begin{array}{l}----\infty \\
----\infty \\
----\end{array}$ \\
\hline & 41 & $\begin{array}{r}52 \\
55 \\
8\end{array}$ & $\begin{array}{l}1.263 \\
1.411 \\
1.577\end{array}$ \\
\hline & 48 & $\begin{array}{r}6 \\
7 \\
10\end{array}$ & $\begin{array}{l}1.433 \\
2.305 \\
1.478\end{array}$ \\
\hline & 55 & $\begin{array}{l}13 \\
17 \\
20\end{array}$ & - \\
\hline
\end{tabular}

*Data omitted due to Lactobacillus growth 
Appendix I (continued)

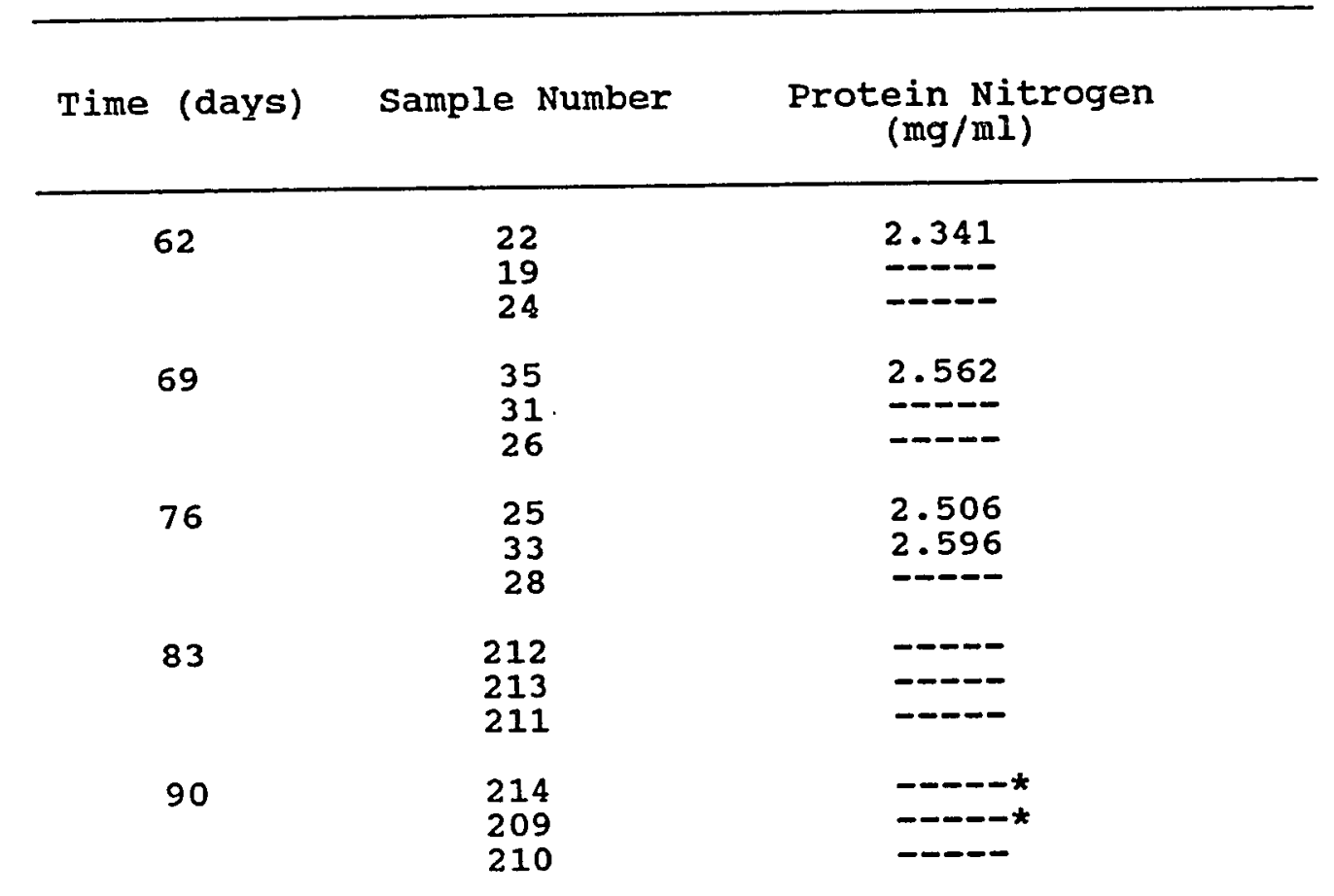

*Data omitted due to Lactobacilius growth 
Appendix $\mathrm{M}$

Data for Drip Volume in the PVDC/EVOH Package

\begin{tabular}{|c|c|c|}
\hline Time (Days) & Sample Number & Exudate Volume (ml) \\
\hline 6 & $\begin{array}{l}80 \\
82 \\
73\end{array}$ & $\begin{array}{l}1.8 \\
6.2 \\
5.5\end{array}$ \\
\hline 13 & $\begin{array}{r}129 \\
46 \\
124\end{array}$ & $\begin{array}{l}3.0 \\
3.0 \\
4.0\end{array}$ \\
\hline 20 & $\begin{array}{l}42 \\
37 \\
43\end{array}$ & $\begin{array}{l}5.0 \\
1.2 \\
9.3\end{array}$ \\
\hline 27 & $\begin{array}{l}125 \\
127 \\
114\end{array}$ & $\begin{array}{l}1.8 \\
5.9 \\
2.9\end{array}$ \\
\hline 34 & $\begin{array}{r}117 \\
120 \\
45\end{array}$ & $\begin{array}{l}3.6 \\
5.0 \\
6.4\end{array}$ \\
\hline 41 & $\begin{array}{r}71 \\
116 \\
84\end{array}$ & $\begin{array}{r}6.3 \\
11.9 \\
6.0\end{array}$ \\
\hline 48 & $\begin{array}{l}3 \\
4 \\
5\end{array}$ & $\begin{array}{l}6.0 \\
4.2 \\
4.0\end{array}$ \\
\hline 55 & $\begin{array}{l}74 \\
76 \\
93\end{array}$ & $\begin{array}{r}11.6 \\
9.1 \\
-.-\end{array}$ \\
\hline 62 & $\begin{array}{l}85 \\
81 \\
86\end{array}$ & $\begin{array}{l}5.0 \\
4.2 \\
6.0\end{array}$ \\
\hline 69 & $\begin{array}{r}113 \\
95 \\
79\end{array}$ & $\begin{array}{r}5.6 \\
7.4 \\
12.8\end{array}$ \\
\hline
\end{tabular}


Appendix (continued)

\begin{tabular}{ccc}
\hline \multirow{2}{*}{ Time (daysj } & Sample Number & Exudate Volume (ml) \\
\hline \multirow{2}{*}{76} & 88 & \\
& 66 & 10.0 \\
68 & 3.2 \\
83 & 91 & 10.2 \\
& 78 & 8.1 \\
90 & 90 & 6.3 \\
& 94 & 5.8 \\
& 103 & 9.4 \\
109 & 5.0 \\
& & 5.6
\end{tabular}




\section{Appendix $\mathrm{N}$ \\ Data for Drip Volume in the NYlon/LLDPE Package}

\begin{tabular}{|c|c|c|c|}
\hline Time (Days) & Sample Number & Exudate Volume & $(\mathrm{ml})$ \\
\hline 6 & $\begin{array}{l}9 \\
2 \\
1\end{array}$ & $\begin{array}{l}1.0 \\
3.0 \\
0.0\end{array}$ & \\
\hline 13 & $\begin{array}{l}57 \\
60 \\
63\end{array}$ & $\begin{array}{l}1.6 \\
1.8 \\
1.0\end{array}$ & \\
\hline 20 & $\begin{array}{l}36 \\
38 \\
44\end{array}$ & $\begin{array}{l}7.8 \\
1.0 \\
2.8\end{array}$ & \\
\hline 27 & $\begin{array}{l}51 \\
54 \\
56\end{array}$ & $\begin{array}{l}8.2 \\
1.4 \\
2.6\end{array}$ & \\
\hline 34 & $\begin{array}{l}53 \\
47 \\
48\end{array}$ & $\begin{array}{l}5.2 \\
5.4 \\
4.6\end{array}$ & \\
\hline 41 & $\begin{array}{r}52 \\
55 \\
8\end{array}$ & $\begin{array}{l}6.2 \\
8.2 \\
4.4\end{array}$ & \\
\hline 48 & $\begin{array}{r}6 \\
7 \\
10\end{array}$ & $\begin{array}{l}3.9 \\
7.0 \\
4.4\end{array}$ & \\
\hline 55 & $\begin{array}{l}13 \\
17 \\
20\end{array}$ & $\begin{array}{l}8.6 \\
7.0 \\
4.4\end{array}$ & \\
\hline 62 & $\begin{array}{l}19 \\
22 \\
24\end{array}$ & $\begin{array}{l}7.0 \\
8.2 \\
2.2\end{array}$ & \\
\hline 69 & $\begin{array}{l}26 \\
31 \\
35\end{array}$ & $\begin{array}{r}8.2 \\
14.2 \\
6.9\end{array}$ & \\
\hline
\end{tabular}


Appendix N (continued)

\begin{tabular}{ccc}
\hline \multirow{2}{*}{ Time (days) } & Sample Number & Exudate Volume (ml) \\
\hline \multirow{2}{*}{76} & 25 & 9.5 \\
& 33 & 10.8 \\
& 28 & --- \\
\multirow{2}{*}{83} & 211 & 3.8 \\
& 212 & 2.0 \\
& 213 & 8.4 \\
90 & 209 & 2.8 \\
& 214 & 3.7 \\
& 210 & --2
\end{tabular}


Appendix 0

Data for Vacuum Retention in the
PVDC/EVOH Package

\begin{tabular}{|c|c|c|c|}
\hline Time & (days) & Sample Number & Vacuum (" Hg) \\
\hline & 6 & $\begin{array}{l}80 \\
82 \\
73\end{array}$ & $\overline{---}$ \\
\hline & 13 & $\begin{array}{r}129 \\
124 \\
46\end{array}$ & $\begin{array}{l}>25.5 \\
>25.5 \\
>25.5\end{array}$ \\
\hline & 20 & $\begin{array}{l}42 \\
37 \\
43\end{array}$ & $\begin{array}{l}>25.5 \\
>25.5 \\
>25.5\end{array}$ \\
\hline & 27 & $\begin{array}{l}125 \\
127 \\
114\end{array}$ & $\begin{array}{l}>25 \\
>25 \\
>25\end{array}$ \\
\hline & 34 & $\begin{array}{r}117 \\
120 \\
45\end{array}$ & $\begin{array}{r}>25 \\
24 \\
24\end{array}$ \\
\hline & 41 & $\begin{array}{r}71 \\
116 \\
84\end{array}$ & $\begin{array}{l}>24.5 \\
>24 \\
15\end{array}$ \\
\hline & 48 & $\begin{array}{l}3 \\
4 \\
5\end{array}$ & $\begin{array}{l}>23.5 \\
>23.5 \\
>23.5\end{array}$ \\
\hline & 55 & $\begin{array}{l}13 \\
17 \\
20\end{array}$ & $\begin{array}{l}>24 \\
>24 \\
>24\end{array}$ \\
\hline & 62 & $\begin{array}{l}85 \\
81 \\
86\end{array}$ & $\begin{array}{l}>24 \\
>24 \\
>24\end{array}$ \\
\hline & 69 & $\begin{array}{r}113 \\
79 \\
95\end{array}$ & $\begin{array}{l}>24 \\
>24 \\
>24\end{array}$ \\
\hline
\end{tabular}


Appendix $\circ$ (continued)

\begin{tabular}{lcc}
\hline \multirow{2}{*}{ Time (days) } & Sample Number & Vacuum (" $\mathrm{Hg})$ \\
\hline \multirow{2}{*}{76} & 88 & 24 \\
& 66 & 29 \\
& 68 & 28 \\
83 & 91 & 28 \\
& 78 & 29 \\
& 90 & 19 \\
90 & 94 & 28 \\
& 109 & 28 \\
& 103 & 25
\end{tabular}


Appendix P

Data for Vacuum Retention in the Nylon/LLDPE Package

\begin{tabular}{|c|c|c|c|}
\hline Time & (days) & Sample Number & Vacuum (" $\mathrm{Hg}$ ) \\
\hline & 6 & $\begin{array}{l}9 \\
2 \\
1\end{array}$ & $\overline{---}$ \\
\hline & 13 & $\begin{array}{l}57 \\
60 \\
63\end{array}$ & $\begin{array}{l}>25.5 \\
>25.5 \\
>25.5\end{array}$ \\
\hline & 20 & $\begin{array}{l}36 \\
38 \\
44\end{array}$ & $\begin{array}{l}>25.5 \\
>25.5 \\
>25.5\end{array}$ \\
\hline & 27 & $\begin{array}{l}51 \\
54 \\
56\end{array}$ & $\begin{array}{l}>25 \\
>25 \\
>25\end{array}$ \\
\hline & 34 & $\begin{array}{l}53 \\
47 \\
48\end{array}$ & $\begin{array}{l}>25 \\
>25 \\
>25\end{array}$ \\
\hline & 41 & $\begin{array}{r}52 \\
55 \\
8\end{array}$ & $\begin{array}{l}>24.5 \\
>24.5 \\
>24.5\end{array}$ \\
\hline & 48 & $\begin{array}{r}6 \\
7 \\
10\end{array}$ & $\begin{array}{l}>23.5 \\
>23.5 \\
>23.5\end{array}$ \\
\hline & 55 & $\begin{array}{l}74 \\
76 \\
93\end{array}$ & $\begin{array}{l}>24 \\
>24 \\
>24\end{array}$ \\
\hline & 62 & $\begin{array}{l}19 \\
22 \\
24\end{array}$ & $\begin{array}{l}>24 \\
>24 \\
>24\end{array}$ \\
\hline & 69 & $\begin{array}{l}26 \\
31 \\
35\end{array}$ & $\begin{array}{l}>24 \\
>24 \\
>24\end{array}$ \\
\hline
\end{tabular}


Appendix P (continued)

\begin{tabular}{lll}
\hline \multirow{2}{*}{ Time (days) } & Sample Number & Vacuum (" Hg) \\
\hline \multirow{2}{*}{76} & 25 & 29 \\
& 28 & 29 \\
33 & 28 & 21 \\
\multirow{2}{*}{83} & 211 & 29 \\
& 212 & 29 \\
& 213 & 15 \\
& 209 & 24 \\
& 214 & -
\end{tabular}




\section{Appendix Q}

Total Psychrophilic plate Counts of the Salmon Samples stored in the PVDC/EVOH Package

\begin{tabular}{|c|c|c|c|}
\hline Time & (days) & Sample Number & $\begin{array}{l}\text { Total Psychrophiles } \\
\text { (Average Count/gram) }\end{array}$ \\
\hline & 6 & $\begin{array}{l}80 \\
82 \\
73\end{array}$ & $\begin{array}{r}10 \\
5 \\
0\end{array}$ \\
\hline & 13 & $\begin{array}{r}129 \\
124 \\
46\end{array}$ & $\begin{array}{r}0 \\
5 \\
10\end{array}$ \\
\hline & 20 & $\begin{array}{l}42 \\
37 \\
43\end{array}$ & $\begin{array}{l}0 \\
0 \\
0\end{array}$ \\
\hline & 27 & $\begin{array}{l}125 \\
127 \\
114\end{array}$ & $\begin{array}{r}0 \\
5 \\
15\end{array}$ \\
\hline & 34 & $\begin{array}{r}117 \\
120 \\
45\end{array}$ & $\begin{array}{r}0 \\
360 \\
0\end{array}$ \\
\hline & 41 & $\begin{array}{r}116 \\
71 \\
84\end{array}$ & $\begin{array}{l}0 \\
0 \\
0\end{array}$ \\
\hline & 48 & $\begin{array}{l}3 \\
4 \\
5\end{array}$ & $\begin{array}{r}0 \\
55 \\
5\end{array}$ \\
\hline & 55 & $\begin{array}{l}74 \\
76 \\
93\end{array}$ & $\begin{array}{r}0 \\
85 \\
70\end{array}$ \\
\hline & 62 & $\begin{array}{l}85 \\
81 \\
86\end{array}$ & $\begin{array}{r}0 \\
0 \\
380\end{array}$ \\
\hline
\end{tabular}


Appendix Q (continued)

\begin{tabular}{lcc}
\hline Time (days) & Sample Number & $\begin{array}{c}\text { Total Psychrophiles } \\
\text { (Average Count/gram) }\end{array}$ \\
\hline \multirow{2}{*}{69} & 113 & 0 \\
& 95 & 0 \\
76 & 88 & 0 \\
& 66 & 0 \\
83 & 68 & TNTC \\
& 91 & 60 \\
& 90 & 0 \\
90 & 78 & 0 \\
& 94 & 50 \\
& 103 & 0 \\
109 & 0 \\
& & 245
\end{tabular}


Appendix $\mathbf{R}$

Total Psychrophilic Plate counts of the salmon samples stored in the Nylon/LLDPE Package

\begin{tabular}{|c|c|c|}
\hline Time (days) & Sample Number & $\begin{array}{l}\text { Total Psychrophiles } \\
\text { (Average count/gram) }\end{array}$ \\
\hline 6 & $\begin{array}{l}9 \\
2 \\
1\end{array}$ & $\begin{array}{l}0 \\
0 \\
0\end{array}$ \\
\hline 13 & $\begin{array}{l}57 \\
60 \\
63\end{array}$ & $\begin{array}{c}\text { TNTC } \\
0 \\
0\end{array}$ \\
\hline 20 & $\begin{array}{l}36 \\
38 \\
44\end{array}$ & $\begin{array}{l}0 \\
6.45 \times 10^{2}\end{array}$ \\
\hline 27 & $\begin{array}{l}51 \\
54 \\
56\end{array}$ & $\begin{array}{r}215 \\
0 \\
0\end{array}$ \\
\hline 34 & $\begin{array}{l}53 \\
48 \\
47\end{array}$ & $\begin{array}{l}0 \\
15 \\
\text { TNTC }\end{array}$ \\
\hline 41 & $\begin{array}{r}52 \\
55 \\
8\end{array}$ & $\begin{array}{l}\text { TNTC } \\
0 \\
0\end{array}$ \\
\hline 48 & $\begin{array}{r}6 \\
7 \\
10\end{array}$ & $\begin{array}{r}0 \\
20 \\
10\end{array}$ \\
\hline 55 & $\begin{array}{l}13 \\
17 \\
20\end{array}$ & $\begin{array}{l}\text { TNTC } \\
25 \\
310\end{array}$ \\
\hline 62 & $\begin{array}{l}19 \\
22 \\
24\end{array}$ & $\begin{array}{l}40 \\
25 \\
\text { TNTC }\end{array}$ \\
\hline
\end{tabular}


Appendix R (continued)

\begin{tabular}{ccc}
\hline Time (days) & Sample Number & $\begin{array}{c}\text { Total } \\
\text { (Average Count/gram) }\end{array}$ \\
\hline \multirow{2}{*}{69} & 26 & 25 \\
& 31 & 5 \\
76 & 35 & 110 \\
& 25 & 285 \\
& 33 & 0 \\
83 & 28 & 205 \\
& 211 & 0 \\
& 212 & 0 \\
90 & 213 & 0 \\
& 209 & 0 \\
& 214 & 0 \\
& 210 & -
\end{tabular}


Appendix $\mathrm{S}$

Lactobacillus Growth in the Salmon Samples stored in the PVDC/EVOH Package

\begin{tabular}{|c|c|c|c|}
\hline Time & (days) & Sample Number & $\frac{\text { Lactobacilii }}{\text { (Average Count/gram) }}$ \\
\hline & 6 & $\begin{array}{l}80 \\
82 \\
73\end{array}$ & $\begin{array}{c}\text { not plated } \\
\text { " }\end{array}$ \\
\hline & 13 & $\begin{array}{r}129 \\
124 \\
46\end{array}$ & $\begin{array}{l}0 \\
0 \\
0\end{array}$ \\
\hline & 20 & $\begin{array}{l}42 \\
37 \\
43\end{array}$ & $\begin{array}{l}0 \\
0 \\
5\end{array}$ \\
\hline & 27 & $\begin{array}{l}125 \\
127 \\
114\end{array}$ & $\begin{array}{r}0 \\
20 \\
0\end{array}$ \\
\hline & 34 & $\begin{array}{r}117 \\
120 \\
45\end{array}$ & not plated \\
\hline & 41 & $\begin{array}{r}116 \\
71 \\
84\end{array}$ & $\begin{array}{l}0 \\
5 \\
0\end{array}$ \\
\hline & 48 & $\begin{array}{l}3 \\
4 \\
5\end{array}$ & $\begin{array}{c}\text { not plated } \\
\text { " }\end{array}$ \\
\hline & 55 & $\begin{array}{l}74 \\
76 \\
93\end{array}$ & not $\underset{\text { plated }}{\text { " }}$ \\
\hline & 62 & $\begin{array}{l}85 \\
81 \\
86\end{array}$ & $\begin{array}{r}0 \\
0 \\
10\end{array}$ \\
\hline
\end{tabular}


Appendix S (continued)

\begin{tabular}{ccc} 
Time (days) & Sample Number & $\begin{array}{c}\text { Lactobacilli } \\
\text { (Average Count/gram) }\end{array}$ \\
\hline \multirow{2}{*}{69} & 113 & not plated \\
& 95 & 11 \\
& 79 & 0 \\
76 & 88 & 10 \\
& 66 & 5 \\
& 68 & not plated \\
83 & 91 & "1 \\
& 90 & 0 \\
90 & 78 & 0 \\
& 94 & 0
\end{tabular}


Appendix T

Lactobacillus Growth in the Salmon Samples stored in the Nylon/LLDPE Package.

\begin{tabular}{|c|c|c|c|}
\hline Time & (days) & Sample Number & (Average Count/gram) \\
\hline & 6 & $\begin{array}{l}9 \\
2 \\
1\end{array}$ & $\begin{array}{c}\text { not plated } \\
\text { " }\end{array}$ \\
\hline & 13 & $\begin{array}{l}57 \\
60 \\
63\end{array}$ & $\begin{array}{l}0 \\
5 \\
0\end{array}$ \\
\hline & 20 & $\begin{array}{l}36 \\
38 \\
44\end{array}$ & $\begin{array}{l}0 \\
0 \\
0\end{array}$ \\
\hline & 27 & $\begin{array}{l}51 \\
54 \\
56\end{array}$ & $\begin{array}{r}0 \\
10 \\
0\end{array}$ \\
\hline & 34 & $\begin{array}{l}53 \\
47 \\
48\end{array}$ & not plated \\
\hline & 41 & $\begin{array}{r}52 \\
55 \\
8\end{array}$ & $\begin{array}{c}\text { TNTC } \\
0 \\
5\end{array}$ \\
\hline & 48 & $\begin{array}{r}6 \\
7 \\
10\end{array}$ & not polated \\
\hline & 55 & $\begin{array}{l}13 \\
17 \\
20\end{array}$ & not plated \\
\hline & 62 & $\begin{array}{l}19 \\
22 \\
24\end{array}$ & $\begin{array}{l}0 \\
0 \\
5\end{array}$ \\
\hline
\end{tabular}


Appendix $T$ (continued)

Time (days) Sample Number

Lactobacilli

(Average Count/gram)

\begin{tabular}{lcc}
\hline 76 & 25 & 0 \\
& 33 & 5 \\
& 28 & 0 \\
69 & 26 & not plated \\
& 31 & not plated \\
& 35 & $" 1$ \\
83 & 211 & \\
& 212 & 40 \\
& 213 & 85 \\
90 & 209 & not plated \\
& 214 &
\end{tabular}


Appendix U

Total Anaerobic/Facultative Growth in the Salmon samples Stored in the PVDC/EVOH Package

\begin{tabular}{|c|c|c|c|}
\hline Time & (days) & Sample Number & $\begin{array}{c}\text { Anaerobes/Facultatives } \\
\text { (Average Count/gram) }\end{array}$ \\
\hline & 6 & $\begin{array}{l}80 \\
73 \\
82\end{array}$ & $\begin{array}{l}0 \\
0 \\
0\end{array}$ \\
\hline & 13 & $\begin{array}{r}129 \\
124 \\
46\end{array}$ & $\begin{array}{r}0 \\
15 \\
5\end{array}$ \\
\hline & 20 & $\begin{array}{l}42 \\
37 \\
43\end{array}$ & $\begin{array}{l}0 \\
0 \\
0\end{array}$ \\
\hline & 27 & $\begin{array}{l}125 \\
127 \\
114\end{array}$ & $\begin{array}{l}0 \\
0 \\
0\end{array}$ \\
\hline & 34 & $\begin{array}{r}117 \\
120 \\
45\end{array}$ & $\begin{array}{l}0 \\
0 \\
0\end{array}$ \\
\hline & $4 i$ & $\begin{array}{r}71 \\
116 \\
84\end{array}$ & $\begin{array}{l}0 \\
0 \\
0\end{array}$ \\
\hline & 48 & $\begin{array}{l}3 \\
4 \\
5\end{array}$ & $\begin{array}{l}0 \\
5 \\
0\end{array}$ \\
\hline & 55 & $\begin{array}{l}74 \\
76 \\
93\end{array}$ & $\begin{array}{l}5 \\
0 \\
0\end{array}$ \\
\hline & 62 & $\begin{array}{l}85 \\
81 \\
86\end{array}$ & $\begin{array}{l}0 \\
0 \\
0\end{array}$ \\
\hline
\end{tabular}


Appendix U (continued)

\begin{tabular}{lcc}
\hline Time (days) & Sample Number & $\begin{array}{c}\text { Anaerobes/Facultatives } \\
\text { (Average Count/gram) }\end{array}$ \\
\hline \multirow{2}{*}{69} & 113 & 0 \\
& 79 & 0 \\
76 & 95 & 0 \\
& 88 & 0 \\
83 & 66 & 0 \\
& 68 & 0 \\
& 90 & 0 \\
90 & 91 & 0 \\
& 78 & 0 \\
& 94 & 0 \\
& 103 & 0 \\
& 109 & 0
\end{tabular}


Appendix V

Total Anaerobic/Facultative Growth in the Salmon Samples stored in the Nylon/LLDPE Package

\begin{tabular}{|c|c|c|c|}
\hline Time & (days) & Sample Number & $\begin{array}{c}\text { Anaerobes/Facultatives } \\
\text { (Average Count/gram) }\end{array}$ \\
\hline & 6 & $\begin{array}{l}9 \\
2 \\
1\end{array}$ & $\begin{array}{r}5 \\
0 \\
10\end{array}$ \\
\hline & 13 & $\begin{array}{l}57 \\
60 \\
63\end{array}$ & $\begin{array}{l}0 \\
0 \\
0\end{array}$ \\
\hline & 20 & $\begin{array}{l}36 \\
38 \\
44\end{array}$ & $\begin{array}{l}0 \\
0 \\
0\end{array}$ \\
\hline & 27 & $\begin{array}{l}51 \\
54 \\
56\end{array}$ & $\begin{array}{l}0 \\
0 \\
0\end{array}$ \\
\hline & 34 & $\begin{array}{l}53 \\
47 \\
48\end{array}$ & $\begin{array}{l}0 \\
0 \\
0\end{array}$ \\
\hline & 41 & $\begin{array}{r}52 \\
55 \\
8\end{array}$ & $\begin{array}{c}\text { TNTC } \\
15 \\
0\end{array}$ \\
\hline & 48 & $\begin{array}{r}6 \\
7 \\
10\end{array}$ & $\begin{array}{l}0 \\
0 \\
0\end{array}$ \\
\hline & 55 & $\begin{array}{l}13 \\
17 \\
20\end{array}$ & $\begin{array}{l}\text { TNTC } \\
25 \\
0\end{array}$ \\
\hline & 62 & $\begin{array}{l}19 \\
22 \\
24\end{array}$ & $\begin{array}{l}0 \\
0 \\
0\end{array}$ \\
\hline
\end{tabular}


Appendix V (continued)

\begin{tabular}{ccc} 
Time (days) & Sample Number & $\begin{array}{c}\text { Anaerobes/Facultatives } \\
\text { (Average Count/gram) }\end{array}$ \\
\hline \multirow{2}{*}{69} & 26 & 0 \\
& 31 & 0 \\
75 & 35 & 0 \\
& 25 & 0 \\
& 33 & 0 \\
83 & 28 & 0 \\
& 211 & 0 \\
& 212 & 0 \\
90 & 213 & 0 \\
& 209 & 0 \\
& 214 & 0 \\
& 210 & not plated
\end{tabular}


Appendix $\mathrm{W}$

Yeast Growth in the Salmon Samples stored in the PVDC/EVOH Package.

\begin{tabular}{|c|c|c|c|}
\hline Time & (days) & Sample Number & $\begin{array}{c}\text { yeasts } \\
\text { (Average Count/gram) }\end{array}$ \\
\hline & 6 & $\begin{array}{l}80 \\
73 \\
82\end{array}$ & $\begin{array}{l}0 \\
0 \\
0\end{array}$ \\
\hline & 13 & $\begin{array}{r}129 \\
124 \\
46\end{array}$ & $\begin{array}{l}0 \\
0 \\
0\end{array}$ \\
\hline & 20 & $\begin{array}{l}42 \\
37 \\
43\end{array}$ & $\begin{array}{l}0 \\
5 \\
0\end{array}$ \\
\hline & 27 & $\begin{array}{l}125 \\
127 \\
114\end{array}$ & $\begin{array}{l}0 \\
0 \\
0\end{array}$ \\
\hline & 34 & $\begin{array}{r}117 \\
120 \\
45\end{array}$ & $\begin{array}{c}\text { not plated } \\
\text { " }\end{array}$ \\
\hline & 41 & $\begin{array}{r}71 \\
116 \\
84\end{array}$ & $\begin{array}{c}\text { not plated } \\
\text { " }\end{array}$ \\
\hline & 48 & $\begin{array}{l}3 \\
4 \\
5\end{array}$ & not $\underset{\text { " plated }}{\text { " }}$ \\
\hline & 55 & $\begin{array}{l}74 \\
76 \\
93\end{array}$ & not plated \\
\hline & 62 & $\begin{array}{l}85 \\
81 \\
86\end{array}$ & not plated \\
\hline
\end{tabular}


Appendix $W$ (continued)

\begin{tabular}{|c|c|c|c|}
\hline Time & (days) & Sample Number & $\begin{array}{c}\text { Yeasts } \\
\text { (Average Count/gram) }\end{array}$ \\
\hline & 69 & $\begin{array}{r}113 \\
79 \\
95\end{array}$ & not plated \\
\hline & 76 & $\begin{array}{l}88 \\
66 \\
68\end{array}$ & $\begin{array}{c}\text { not plated } \\
\text { " }\end{array}$ \\
\hline & 83 & $\begin{array}{l}90 \\
91 \\
78\end{array}$ & not plated \\
\hline & 90 & $\begin{array}{r}94 \\
103 \\
109\end{array}$ & $\begin{array}{l}0 \\
0 \\
0\end{array}$ \\
\hline
\end{tabular}


Appendix $\mathrm{X}$

Yeast Growth in the Salmon Samples stored in the Nylon/LLDPE Package

\begin{tabular}{|c|c|c|c|}
\hline Time & (days) & Sample Number & $\begin{array}{c}\text { Yeasts } \\
\text { (Average Count/gram) }\end{array}$ \\
\hline & 6 & $\begin{array}{l}9 \\
2 \\
1\end{array}$ & $\begin{array}{l}0 \\
0 \\
0\end{array}$ \\
\hline & 13 & $\begin{array}{l}57 \\
60 \\
63\end{array}$ & $\begin{array}{l}0 \\
0 \\
0\end{array}$ \\
\hline & 20 & $\begin{array}{l}36 \\
38 \\
44\end{array}$ & $\begin{array}{l}0 \\
0 \\
0\end{array}$ \\
\hline & 27 & $\begin{array}{l}51 \\
54 \\
56\end{array}$ & $\begin{array}{l}0 \\
0 \\
0\end{array}$ \\
\hline & 34 & $\begin{array}{l}53 \\
47 \\
48\end{array}$ & not plated \\
\hline & 41 & $\begin{array}{r}52 \\
55 \\
8\end{array}$ & $\begin{array}{c}\text { not plated } \\
\|\end{array}$ \\
\hline & 48 & $\begin{array}{r}6 \\
7 \\
10\end{array}$ & $\begin{array}{c}\text { not plated } \\
\text { " }\end{array}$ \\
\hline & 55 & $\begin{array}{l}13 \\
17 \\
20\end{array}$ & not plated \\
\hline & 62 & $\begin{array}{l}19 \\
22 \\
24\end{array}$ & $\begin{array}{c}\text { not plated } \\
\text { " }\end{array}$ \\
\hline
\end{tabular}


Appendix X (continued)

\begin{tabular}{|c|c|c|c|c|}
\hline Time & (days) & Sample Number & $\begin{array}{c}\text { yeas } \\
\text { (Average }\end{array}$ & $\begin{array}{l}\text { asts } \\
\text { Count/gr }\end{array}$ \\
\hline & 69 & $\begin{array}{l}26 \\
31 \\
35\end{array}$ & not & $\begin{array}{l}\text { plated } \\
\text { " }\end{array}$ \\
\hline & 76 & $\begin{array}{l}25 \\
33 \\
28\end{array}$ & not & $\begin{array}{l}\text { plated } \\
\text { " }\end{array}$ \\
\hline & 83 & $\begin{array}{l}211 \\
212 \\
213\end{array}$ & not & $\begin{array}{l}\text { plated } \\
\text { " }\end{array}$ \\
\hline & 90 & $\begin{array}{l}209 \\
214 \\
210\end{array}$ & not & $\begin{array}{l}0 \\
5 \\
\text { plated }\end{array}$ \\
\hline
\end{tabular}


Appendix $Y$

Hunter Color Data

\begin{tabular}{|c|c|c|c|c|c|c|c|}
\hline \multirow[b]{2}{*}{ Time (days) } & \multirow[b]{2}{*}{ Sample } & \multicolumn{3}{|c|}{ Initial Values } & \multicolumn{3}{|c|}{ Final Volues } \\
\hline & & $\mathbf{L}$ & a & b & $\mathbf{L}$ & a & b \\
\hline \multirow[t]{6}{*}{6} & 80 & 68.6 & 12.5 & 14.6 & 68.6 & 12.5 & 14.6 \\
\hline & 82 & 64.7 & 17.2 & 15.7 & 64.7 & 17.2 & 15.7 \\
\hline & 73 & 67.4 & 10.0 & 13.9 & 67.4 & 10.0 & 13.9 \\
\hline & 9 & 74.4 & 16.5 & 17.1 & 74.4 & 16.5 & 17.1 \\
\hline & 2 & 58.9 & 14.7 & 9.4 & 58.9 & 14.7 & 9.4 \\
\hline & 1 & 73.5 & 14.1 & 15.8 & 73.5 & 14.1 & 15.8 \\
\hline \multirow[t]{6}{*}{13} & 129 & 57.6 & 13.9 & 11.9 & 67.2 & 11.4 & 15.8 \\
\hline & 46 & 66.4 & 21.3 & 14.8 & 70.0 & 16.3 & 15.4 \\
\hline & 124 & 69.5 & 18.5 & 15.2 & 70.7 & 15.6 & 15.7 \\
\hline & 57 & 73.0 & 19.5 & 17.9 & 70.8 & 17.0 & 16.5 \\
\hline & 60 & 63.7 & 18.2 & 15.9 & 62.6 & 13.8 & 14.7 \\
\hline & 63 & 66.3 & 21.1 & 16.2 & 62.8 & 18.2 & 14.7 \\
\hline \multirow[t]{6}{*}{20} & 42 & 68.1 & 14.4 & 13.5 & 68.5 & 18.5 & 15.4 \\
\hline & 37 & 68.6 & 95.2 & 15.1 & 66.5 & 12.5 & 15.1 \\
\hline & 43 & 61.1 & 22.4 & 11.2 & 65.0 & 22.9 & 16.3 \\
\hline & 36 & 68.0 & 17.4 & 15.0 & 73.8 & 23.3 & 14.4 \\
\hline & 38 & 63.6 & 16.2 & 14.0 & 65.9 & 23.5 & 13.9 \\
\hline & 44 & 73.5 & 11.5 & 17.2 & 72.2 & 16.7 & 16.3 \\
\hline \multirow[t]{6}{*}{27} & 125 & 72.8 & 13.0 & 14.1 & $\pi 5.6$ & 17.3 & 15.8 \\
\hline & 127 & 69.4 & 18.2 & 15.9 & 66.8 & 27.4 & 13.4 \\
\hline & 114 & 79.0 & 19.8 & 15.7 & 67.5 & 26.2 & 12.2 \\
\hline & 51 & 66.6 & 20.5 & 15.5 & 60.0 & 30.3 & 11.7 \\
\hline & 54 & 72.2 & 17.7 & 16.1 & 69.6 & 27.4 & 12.7 \\
\hline & 56 & 67.2 & 20.0 & 15.3 & $\Leftrightarrow .2$ & 31.6 & 16.0 \\
\hline \multirow[t]{3}{*}{34} & 117 & 69.7 & 16.5 & 13.3 & 70.6 & 11.9 & 15.4 \\
\hline & 45 & 66.8 & 14.2 & 15.5 & 67.7 & 13.5 & 15.7 \\
\hline & 120 & 68.9 & 17.9 & 14.2 & 68.6 & 15.9 & 14.8 \\
\hline \multirow{3}{*}{-} & 53 & 72.9 & 18.8 & 17.0 & $\mathbf{T 5} .0$ & 17.1 & ia.1 \\
\hline & 48 & 70.1 & 22.6 & 16.2 & 68.4 & 19.5 & 16.9 \\
\hline & 47 & 71.8 & 16.6 & 15.3 & 68.8 & 15.7 & 13.8 \\
\hline
\end{tabular}


Appendix Y (continued)

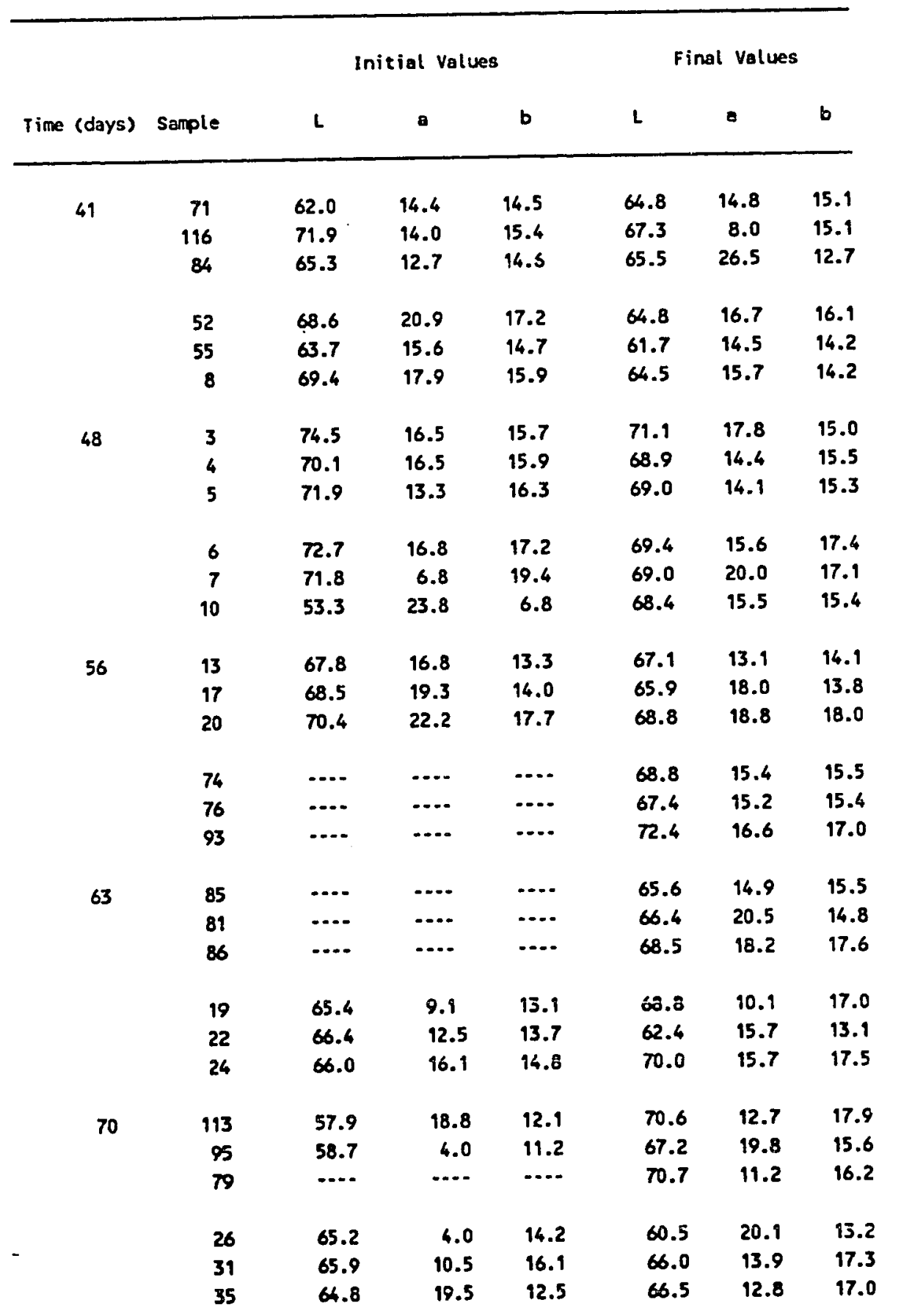


Appendix Y (continued)

\begin{tabular}{|c|c|c|c|c|c|c|c|}
\hline \multirow[b]{2}{*}{ Time (days) } & \multirow[b]{2}{*}{ Sample } & \multicolumn{3}{|c|}{ Initial Volues } & \multicolumn{3}{|c|}{ Finsl Volues } \\
\hline & & 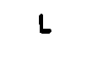 & $\bullet$ & b & $L$ & - & $\mathbf{b}$ \\
\hline \multirow[t]{6}{*}{$\pi$} & 88 & 66.4 & 12.6 & 14.6 & 67.0 & 13.2 & 16.3 \\
\hline & 68 & 71.1 & 16.1 & 17.6 & 68.7 & 15.5 & 17.4 \\
\hline & 66 & 69.2 & 12.6 & 14.8 & 72.7 & 14.0 & 16.5 \\
\hline & 25 & 67.6 & 8.3 & 15.8 & 68.1 & 14.5 & 16.5 \\
\hline & 33 & 62.1 & 11.4 & 12.7 & 68.2 & 13.9 & 16.3 \\
\hline & 28 & 71.8 & 14.2 & 17.0 & 66.8 & 15.8 & 15.3 \\
\hline \multirow[t]{6}{*}{84} & 91 & 67.7 & 17.3 & 14.9 & 65.7 & 15.6 & 14.3 \\
\hline & $7 B$ & 72.3 & 21.5 & 18.5 & 65.2 & 13.4 & 16.5 \\
\hline & 90 & 71.5 & 17.0 & 15.0 & 68.8 & 12.7 & 15.9 \\
\hline & 211 & 69.8 & 13.5 & 14.9 & 67.6 & 13.0 & 14.1 \\
\hline & 212 & 71.7 & 16.6 & 16.7 & 68.4 & 15.9 & 15.8 \\
\hline & 213 & 67.8 & 14.1 & 15.2 & 65.3 & 13.7 & 14.2 \\
\hline \multirow[t]{6}{*}{91} & 94 & 70.3 & 17.5 & 17.9 & 63.9 & 14.9 & 16.0 \\
\hline & 103 & 73.9 & 12.4 & 15.3 & 63.5 & 13.6 & 15.2 \\
\hline & 109 & 65.4 & 17.7 & 14.6 & $\$ 6.7$ & 15.2 & 13.7 \\
\hline & 209 & 71.6 & 15.2 & 15.6 & 66.5 & 17.3 & 93.5 \\
\hline & 214 & 71.2 & 16.5 & 15.5 & 67.6 & 18.2 & 14.2 \\
\hline & 210 & .... & .... & $\ldots$ & $\cdots$ & $\cdots$ & $\cdots$ \\
\hline
\end{tabular}

